THE PERSPECTIVES AND EXPERIENCES OF AFRICAN AMERICAN FEMALE ELEMENTARY SCHOOL PRINCIPALS

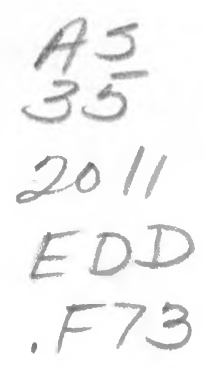

A dissertation submitted to the faculty of San Francisco State University in partial fulfillment of the Requirements for the Degree

\title{
Doctor of Education
} in

Educational Leadership

\section{by}

Vidrale Antoinette Franklin

San Francisco, California

May 2011 
Copyright by

Vidrale Antoinette Franklin 2011 


\section{CERTIFICATION OF APPROVAL}

I certify that I have read The Perspectives and Experiences of African American Female Elementary School Principals by Vidrale Antoinette Franklin, and that in my opinion this work meets the criteria for approving a dissertation submitted in partial fulfillment of the requirements for the degree: Doctor of Education in Educational Leadership at San Francisco State University.

Tamal Co6ks, Ph.D.

Associate Professor, College of Education San Francisco State University

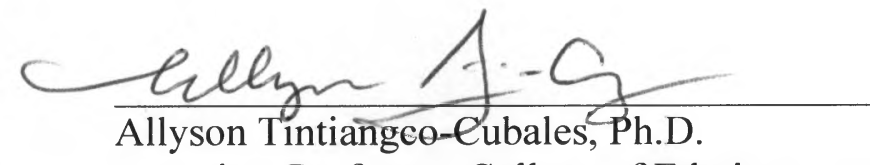
Associate Professor, College of Ethnic Studies

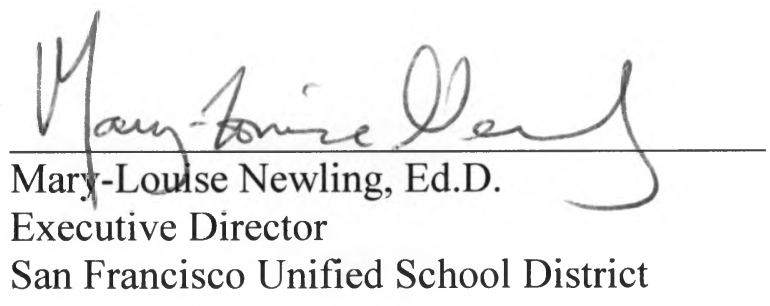




\title{
THE PERSPECTIVES AND EXPERIENCES OF AFRICAN AMERICAN FEMALE ELEMENTARY SCHOOL PRINCIPALS
}

\author{
Vidrale Antoinette Franklin \\ San Francisco State University \\ 2011
}

Through narrative inquiry, a qualitative study of the lived experiences of six African American female elementary school principals in two urban districts was conducted within the theoretical frameworks of Black feminist and critical race theories. The study examined how race and gender influence the role of African American female elementary principals, the challenges they encounter and the support structures they utilize to sustain in their positions. The data reveal that race and gender statuses were significant factors in shaping their roles as school site administrators and that these women face unique challenges related to their identification as Black and female. Additionally, each story reveals how professional networks, family and spirituality support them in their efforts to lead urban schools. This dissertation provides three pillars which can be used to effectively support African American female elementary school principals in their complex roles as urban school leaders.

I certify that the Abstract is a correct representation of the content of this dissertation.

Jamal Cooks, Ph.D.

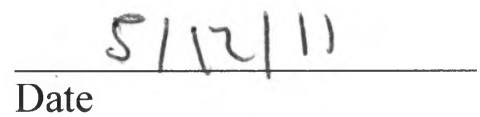
Chair, Dissertation Committee 


\section{ACKNOWLEDGEMENTS}

My sincerest appreciation goes out to my dissertation chairperson, Dr. Jamal Cooks whose laid-back approach lowered my anxiety level and helped me navigate through this very challenging and emotional process. I am also thankful for the support of my committee members: Dr. Allyson Tintiangco-Cubales, you have inspired me to go far beyond what I thought was possible as a woman of color. I am grateful to have benefitted from your knowledge and "revolutionary" spirit; Dr. Mary-Louise Newling, that you so much for supporting me on both a personal and professional level.

To my wonderful family, thank you for your understanding, patience and support. To my grandparents, Myrtis Douglas, Benjamin and Bessie Franklin, I know how much this means to you. I hold your stories of the past in my heart and soul and those stories sustain me, prepare me and give me hope for the future. To my mother and father, Keith and Debra Franklin, I will never be able to repay you for all you've given me. I owe you everything. To my husband, Tim Kelly, you have been so supportive. I love dearly. Thank you for hanging in there with me. To my sister, Lakesha, niece, Keir, and nephew, Keshon, you inspire me to be my best so that I inspire you.

Thank you to the six women who participated in this study. Your voices must be heard and your stories matter.

Lastly, thank God for all my blessings - past, present and future. Despite every roadblock, every obstacle and every barrier, I did it. With You, I can do anything. Just tell me what's next, Lord. 


\section{TABLE OF CONTENTS}

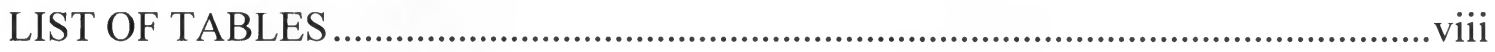

LIST OF FIGURES .........................................................................................

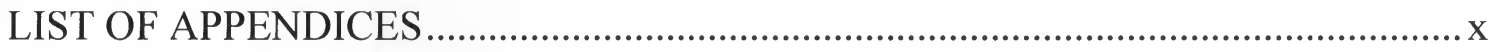

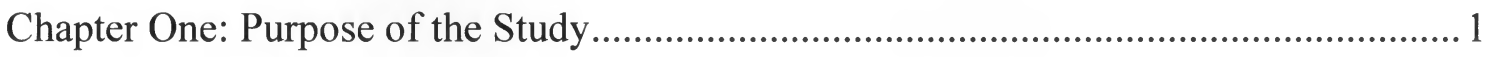

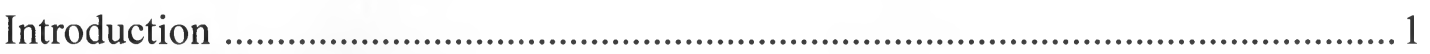

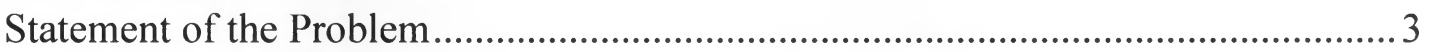

Purpose of the Study ......................................................................................... 4

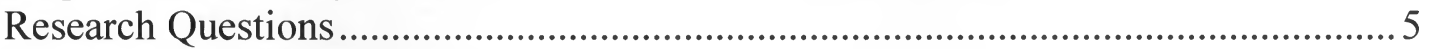

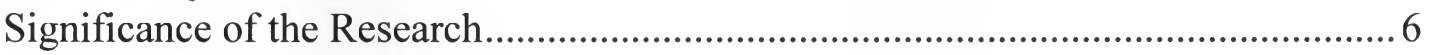

Theoretical Framework ......................................................................................

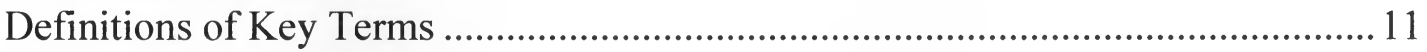

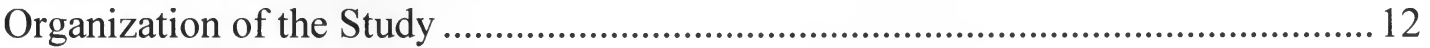

Chapter Two: Literature Review .................................................................................. 14

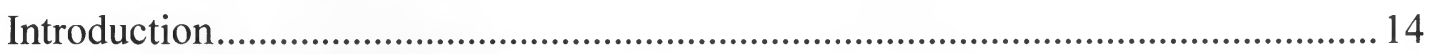

History of African American Female Principals ......................................................... 14

The Brown Decision and Its Impact on African American School Leaders..............25

African American Female Principals in the Years Beyond Brown ..........................22

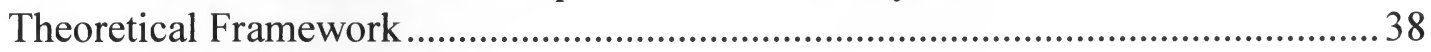

Black Feminist Theory............................................................................ 38

Critical Race Theory ...................................................................................... 43

The Intersection of Black Feminist and Critical Race Theories ..................... 48

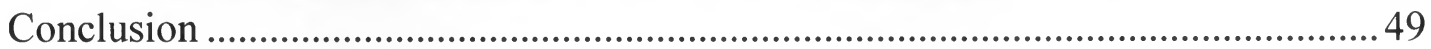

Chapter Three: Research Method .............................................................................52

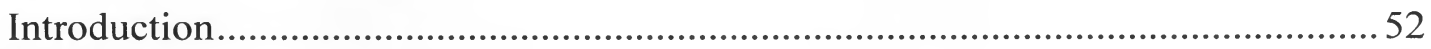

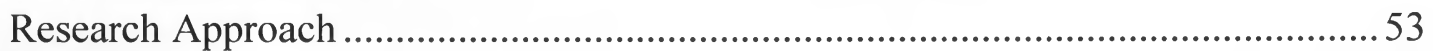

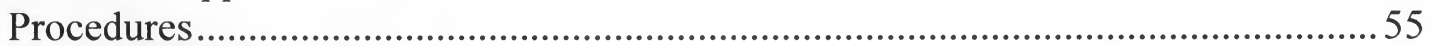

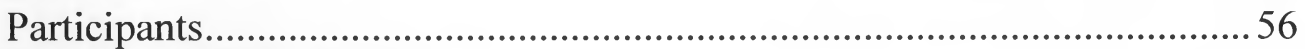

Description of the Participants.....................................................................5 57

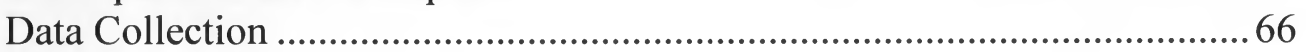

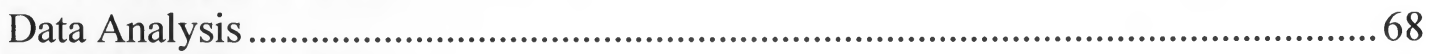

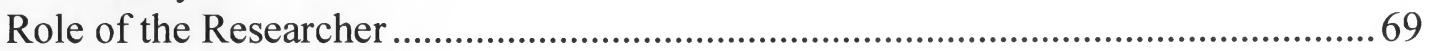


Chapter Four: Report of Findings .................................................................................

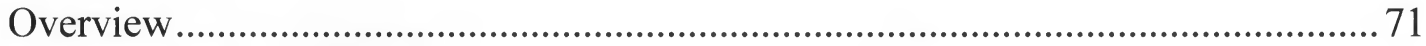

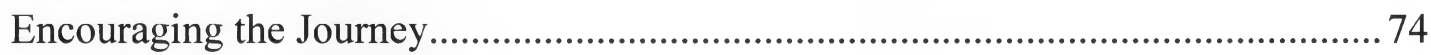

Race, Gender and Leadership ................................................................................ 85

Placement and Career Advancement ............................................................. 85

Prove Yourself ..................................................................................... 89

Challenges and Barriers to Success ........................................................................... 94

Defining Their Roles as Urban School Leaders ....................................................... 103

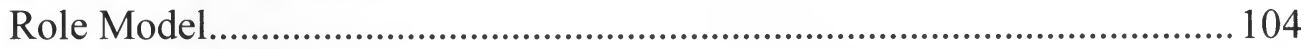

Role Model and Ambassador........................................................................ 107

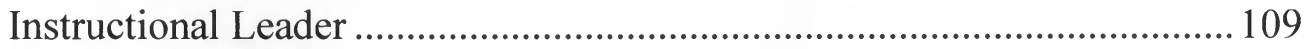

Community Partner and Resource ............................................................ 113

Advocate for Black Children .................................................................... 119

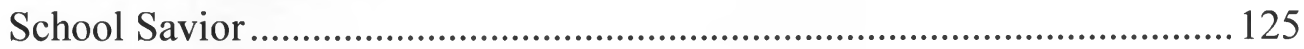

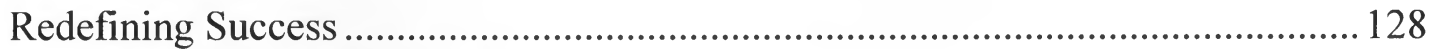

Supports and Facilitators to Success..................................................................... 135

Supportive Social Networks ...................................................................... 135

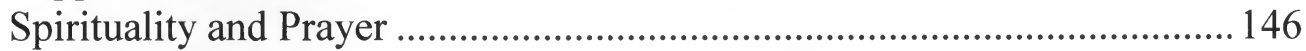

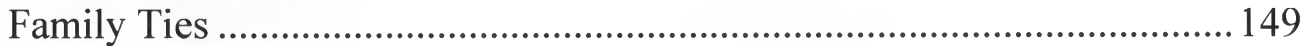

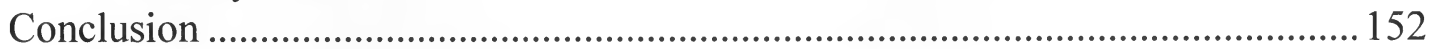

Chapter Five: Discussion and Recommendations....................................................... 153

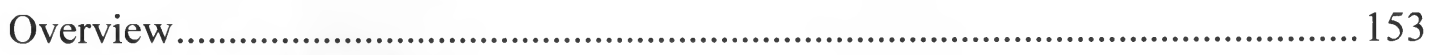

Interpretation of Findings ………………………………................................... 155

The Role of African American Female School Leaders................................ 156

The Challenges Faced by African American Female School Leaders ........ 162

The Supports Utilized by African American Female School Leaders......... 168

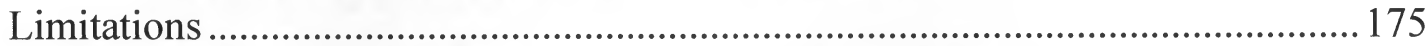

Pillars of Effective Support of African American Female Principals...................... 176

Pillar One: It Takes a Village...................................................................... 178

Pillar Two: Each One, Teach One; Each One, Reach One ............................ 180

Pillar Three: Lift Every Voice ...................................................................... 184

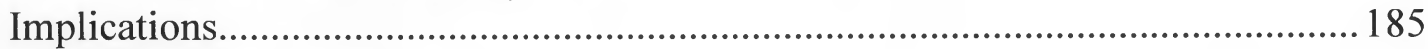

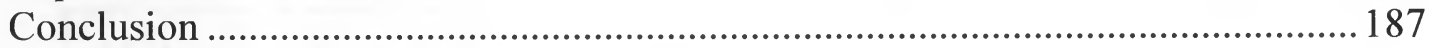

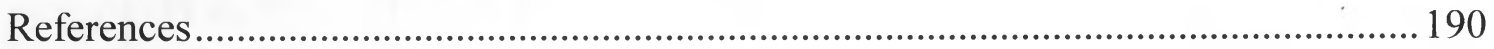

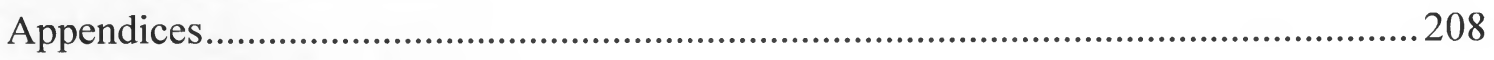




\section{LIST OF TABLES}

Table

Page

1. Demographic Data of Study Participants ....................................................... 58

2. Student Demographic Data of Schools Lead by Study Participants ....................... 58

3. Teacher Demographic Data of Schools Lead by Study Participants ...................... 59 


\section{LIST OF FIGURES}

Figure

Page

1. Interrelationship of Personal and Leadership Experiences

74

2. Pillars of Effective Support 188 


\section{LIST OF APPENDICES}

Appendix $\quad$ Page

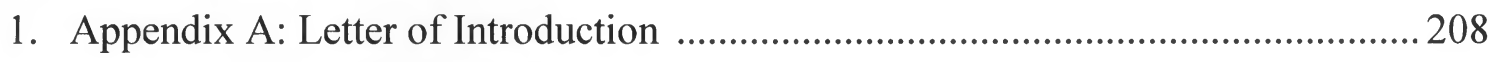

2. Appendix B: Consent Forms ......................................................................... 209

3. Appendix C: Demographic Questionnaire ...................................................... 212

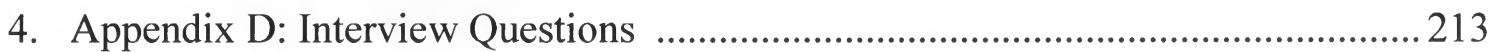




\section{Chapter One: Purpose of the Study}

\section{Introduction}

Demographic shifts among the nation's student population have changed the face of public education leading to more racial and ethnic diversity. White students are continually being replaced with students from various cultural, racial and linguistic backgrounds especially in the nation's urban centers. Current data supplied by the US Department of Education indicate that within the population of P-12 students, the percentage of students of color is increasing, and further indicate that by the year 2020 nearly half of all students in the P-12 education system will be of color (Gollnick \& Chinn, 2005). At the same time, demographic shifts among school site administrators are also occurring with more and more people of color taking on leadership roles. According to the National Center for Educational Statistics, $17 \%$ of public school site leaders at the elementary and secondary levels represent minority groups with African American women representing a significant portion of this group. National data also indicate that women constitute $47.6 \%$ of all P-12 school site administrators and hold the majority of positions at the elementary level at 52\%. Furthermore, African Americans represent $10.6 \%$ of all P-12 principals and $10.9 \%$ at the elementary school level.

While the number of African American women assuming leadership positions is on the rise, research that examines and documents their unique experiences as members of underrepresented groups is minimal. Much of the research on African American 
women and their underrepresentation in educational leadership focuses on administrators at the levels of the superintendency and above (Alston, 2005; Waring, 2003), career ascension (Brunner, 1999), leadership style (Bolman \& Deal, 1997; Brown, 2005); or the research examines this group of leaders solely in terms of their gender within the context of corporate and political settings (Bloom \& Erlandson, 2003). Few studies document the experiences of African American women at the elementary. According to Bloom (2003), the experiences of African American female educational leaders differ vastly from those of white males, a group who has dominated the field and research. For example, African American women typically hold positions in urban settings and lead schools with nearly insurmountable challenges and in disproportionate numbers (Bloom \& Erlandson, 2003; Tillman, 2004a). These leaders are generally placed in schools located in depressed neighborhoods with inadequate financial resources, insufficient instructional materials, inexperienced teachers and low student achievement (Bloom \& Erlandson, 2003). Bloom and Erlandson further attest that "school district superintendents and school boards tend to offer administrative opportunities to African American women to salvage their own people (p. 346)" essentially forcing them to "tak[e] on the role of a 'messiah' or eventually becoming a 'scapegoat' (p. 346). By offering African American women leadership positions in the most challenging urban schools while providing limited resources, and holding them solely liable for the failure of these schools, districts are contributing to the notion of a 
lack of skill and ability when it comes to the quality of Black female leadership at the elementary level.

As a growing number of African American women seek educational leadership opportunities, the examination of the experiences of African American female principals and their perspectives may provide a wealth of information in terms of what motivates and sustains this group of leaders.

\section{Statement of the Problem}

Although the face of the school site leader in the US is slowly changing, with an increased number of African American female principals heading the nation's public schools, a paucity of research exists that examines the experiences of African American female school site leaders. This group has been historically absent from research that has routinely documented the experiences of white males who have dominated leadership positions in public schools (Tillman, 2004a). Therefore, research is needed to document the experiences of African American female principals in the urban school setting, from the perspective of black women, giving voice to a group that has essentially been silenced. Because their experiences as members of two underrepresented communities are unique in comparison to those of the dominant culture, highlighting and describing the challenges these women encounter leading culturally and linguistically diverse school communities are critical in understanding the experiences of a growing population. 
Research is needed that seeks to illuminate and document the experiences and perspectives of African American female principals in the urban school setting.

Professional literature in this area will validate the experiences of an underrepresented group that played a key role in the education of a growing student population. This research will not only document the latest experiences of African American female school leaders, but will give voice to a group that is often overlooked. Furthermore, this study will add to the literature on the phenomenology of leading urban schools from the perspective of the African American female. This study will also draw attention to the unique experiences of African American female principals, describing in detail the challenges they face, ways in which they sustain themselves in their positions and what supports they perceive are needed to effectively lead urban schools. Lastly, this study seeks to provide an analysis of the lived experiences of African American females leading urban schools as a reference for other African American women who aspire to lead in such settings.

\section{Purpose of the Study}

The purpose of this study is to examine the lived experiences of six African American female administrators leading elementary schools in the San Francisco Bay Area. This study employed a phenomenogical approach in an attempt to highlight the experiences of African American female principals in urban school settings and to identify commonalities in their experiences. The findings of this study will serve to: (a) 
document the unique experiences of African American female administrators at the elementary school level; (b) examine the factors that contribute to their ability to persevere in their positions despite the presence of challenges associated with urban schools; (c) determine factors that challenge them in their roles as leaders; and (d) identify the supports they perceive are needed to assist them in their efforts to lead urban schools.

The results of the study also seek to fill the gap in the current body of knowledge about the experiences of African American female school site administrators and broaden the discourse in educational leadership by focusing on the perspectives of African American female principals at the elementary level. Although the focus of this study will be limited to principals in a specific geographic area, the results may be beneficial to the further study of the barriers and supports to successful leadership for African American women in urban elementary schools.

\section{Research Questions}

Changing demographics in the public education system reveal that more and more students of color are filling the nation's classrooms. Reflecting this change is the increasing number of people of color charged with leading these schools (Tillman, 2004a, Pollard, 1997; Bloom \& Erlandson, 2003). Murtadha and Larson (1999) assert that “... principals of color, especially African American women, typically emerge as the leaders of urban schools that are undersupported and economically depleted" (p. 6). 
Thus, supporting these leaders is a key component in the academic success of many of the nation's children coupled with the fact that research on this group of educators is sparse form a basis for deeper exploration. Therefore, my research question is as follows:

What are the personal and professional experiences of African American female elementary school principals?

From this central question, I formulated the following secondary research questions: What are challenges faced by African American women in their roles as elementary school leaders?

What supports do African American female elementary school leaders utilize and require to sustain in their positions as urban school leaders charged with improving teaching and learning?

\section{Significance of the Research}

African American school site leadership is an area of research that has not been heavily examined (Bloom \& Erlandson, 2003). As Bloom and Erlandson (2003) state, "An extensive search for dedicated qualitative or quantitative research on Black women principals in education produced limited results" (p. 343). They found that much of the information concerning African American women in leadership is positioned within the larger context of research on women in general. They further contest that studies on and conducted by African American women largely fail to be published in professional 
research journals and are often regarded as questionable and imprecise (Bloom \& Erlandson, 2003).

This paucity in the research is undoubtedly a cause for concern. However, it can also be looked upon as an opportunity to garner new information concerning African American female school site administrators, their voices, views, and values, and the challenges they encounter leading urban public schools. African American females have unique experiences that have yet to be examined on a large scale. As Banks (1995) states, "Despite the growing number of research on, and conducted by people of color in educational leadership, women and people of color are adding an exciting element to the study of leadership" (p. 66). She goes on to assert, "their work raises new questions ... challenges traditional leadership theory ... redefines old concepts and presents new language to describe leadership ... and is helping to create a new vision of leadership" (p. 66). By employing a research design that attempts to capture the participants' personal and professional stories as told in their own voices, the systems and structures that reinforce racial hegemony in the dominate discourse are challenged.

\section{Theoretical Framework}

School leadership has transformed greatly in recent years. Certain groups, in particular, face increasing challenges as they strive to improve student learning. Schools exist in a society plagued by gender discrimination and racism and it is within this context that female and minority administrators must navigate to achieve success within 
their roles as leaders. Gardiner et al. (2000) state, "Administrators who are women, white and of color, are struggling to find their own voices as they bring their unique heritages to the bureaucracy of schools" (p. 26). Because women are often seen as nurturing and concerned with relationships, they are typically not thought to hold the inherent characteristics seen as prerequisite to leadership (Harder \& Waldo, 1983).

For minority women, particularly African American women, navigating in a world dominated by white males presents challenges that are gender-based and that are also compounded by race. According to King (1995), African American women who hold leadership positions in education are often the victims of double jeopardy. Not only do they experience inequity and negative perceptions based on gender, they also experience oppression as a result of their race. Dardaine-Ragguet et al. (1994) state, "Black women face even more discrimination than Black men since either their gender or their race may evoke negative responses from employers" (p. 405). As African Americans and women, this group of leaders face unique challenges based on their race and gender and must find equally unique ways of meeting those challenges in an effort to successfully perform their duties as urban school leaders.

The lived experiences of African American female elementary school leaders are vast and complex. As a Black woman principal, my racial identity and gender influence my role as a leader in terms of how I perform my duties and how I am perceived by others. As a result of my experiences, I have chosen Black feminist theory 
and critical race theory as the theoretical lens through which to examine the lived experiences of African American female elementary school principals.

The experiences of African American women school leaders at the elementary level have largely gone unnoticed. A small number of research studies have examined the leadership functions of this group of leaders operating on the margins of society (Bloom \& Erlandson, 2003; Pollard, 1997). However, little is known about how this group of leaders contributes to the education of urban students. Identifying as both African American and female, locates these women in a unique space within American society. Black feminist theory recognizes the intersection of race, gender and class in the experiences and perceptions of African American women and how this intersection produces distinctive systems of oppression for Black women in the U.S. According to Collins (2009), Black feminist theory seeks to "empower African American women within the context of social injustice sustained by intersecting oppressions" (p. 25-26). One mechanism of empowerment proposed by Collins is self-definition and selfvaluation. Collins proposes that by defining one's image, African American women resist the perceptions of the dominate culture that has objectified Black women as "the other" (p. 110). In addition, Black feminist theory addresses the importance African American women as the voice of their own experiences, thoughts, ideas and perspectives. The lack of voice and exclusion of African American women as writers of their own stories relegates Black women to the margins of society. Using the Black 
female voice to redefine the images of African American women in America moves Black women from the margins to the center and begins to chip away at the walls of oppression and domination. As the voices of African American female elementary school principals continue to rise, their experiences may perhaps be validated as meaningful contributions to education research and practice.

This study is also examined through the lens of critical race theory. Critical race theory is a belief brought forth by a collection of activists and scholars who seek to explore and transform the relationship between race, racism and power (Crenshaw, 1988; Delgado, 1995; Solorzano, Ceja, \& Yosso, 2000). Crenshaw et al. (1995), asserts that critical race theory, "aims to examine the terms by which race and racism have been negotiated in American consciousness, and to recover and revitalize the radical tradition of race-consciousness among African Americans and other peoples of color ... " ( $p$. xiv). Critical race theory is essential in this study because racism exist as a permanent feature in American society and significantly affects the experiences of African American women in educational leadership positions. This normalcy contributes to the perpetuation of racist and oppressive practices within societal structures and institutions and serves to keep members of the dominate group in power and members of marginalized groups from accessing power. Critical race theory offers members of marginalized groups as a vehicle of resistance counterstorytelling which provides a space for these groups to articulate their lived experiences and perceptions through a 
racialized lens. These stories challenge the dominate discourse and provide a space for engaging and countering negative stereotyping (Taylor, 2004).

\section{Definitions of Key Terms}

Academic Performance Index - a measurement of academic performance and growth of individual schools in California.

African American - describes people of color who are of Black African descent. For the purposes of this study the terms African American and Black are used interchangeably.

Community - a group of individuals sharing a particular space or area, and taking common ownership for the wellness of that space.

Elementary School - a public institution of teaching and learning that includes prekindergarten through sixth grade students

High Performing School - a school that is successful as determined by the state Academic Performance Index standard of 800.

Principal - the instructional leader and director of a school who takes responsibility for the practices and procedures that contribute to teaching and learning. For the purposes 
of this study the terms principal, administrator and school leader are used interchangeably.

Public school - a school that is supported by public funding.

Spirituality - a belief in a power that is operating in the universe that is greater than oneself; a belief in God.

Urban School - public school within a district located in a metropolitan area where the schools are predominately comprised of students of color who are economically disadvantaged.

\section{Organization of the Study}

This dissertation is divided into five chapters. The remaining four chapters include:

Chapter Two begins with a summary of the literature on African American leaders in education field from the period before the landmark Brown v. Board of Education decision followed by an examination of the literature on African American female school leadership specifically. This chapter also reviews the theoretical discourses that position and define the African American female elementary school principal's struggle through the lens of black feminist thought and critical race theory. 
Chapter Three offers a rationale for using narrative inquiry to gain insight into the lived experiences of African American female elementary school principals. The chapter also provides a description of the participants, instrumentation, method for collecting data, and data analysis procedures.

Study findings are presented in Chapter Four. An analysis of the data collected along with narrative themes, relationships between findings and the literature, and a summary on the findings of the study are also offered.

Chapter Five presents a summary and interpretation of the findings as well as implications and recommendations for future practice and subsequent research. 
Chapter Two: Literature Review

Introduction

The purpose of the this study was to understand the perspectives and experiences of African American female elementary school principals and to explore how these leaders confront race, gender and class inequality as they work to successfully educate students in urban school environments. The review of the literature begins with an overview of African American education leaders from the pre-Brown era to the landmark legal decision followed by an examination of African American female leadership specifically. In this chapter, I also review the theoretical discourses that position and define the African American female elementary school principal's struggle through the lens of black feminist theory and critical race theory.

\section{History of African American Female Principals}

African Americans and schooling were once considered incompatible in the United States. Until the late $19^{\text {th }}$ century, learning to read, write or gain any knowledge outside of the scope of plantation field labor and house work was essentially forbidden for Blacks (Carruthers, 1994; Ladson-Billings, 1994). One of the earliest documented reports of state legislation prohibiting the education of African Americans dates back to 1740 when South Carolina enacted a law that forbid slaves to write (Franklin, 1990). Nearly 100 years later, several more states, including Mississippi, Delaware, Virginia and North Carolina passed laws that made it illegal to educate African Americans 
(Savage, 2001; Tillman, 2004a). This prohibition was, in large part, driven by the concern of slave uprising by White owners. The fears of slave rebellion and the proliferation of abolitionist materials and philosophy fueled restrictions on the assembling of slaves, their travel, and their education (Webber, 1978). In 1826, a school opened by Daniel Payne in Charleston, South Carolina fell victim to such fear. After eight years of educating African American children and adults, the school was forced to close its doors after the state banned schools from teaching slaves and free Blacks to read and write. The illiteracy and, consequently, ignorance of slaves was considered necessary to protect the status of White slaveholders and ensure the continued oppression of their Black servants (Albanese, 1976).

Emerging from the clutches of slavery in the late $19^{\text {th }}$ century, efforts were made to provide academic and other educational support to newly freed Blacks (Franklin, 1984; Savage, 2001; Siddle Walker, 1996; Tillman, 2004a). Institutions like the Freedmen's Schools were established and funded by African Americans, the Federal government and missionaries from northern states to develop educational and social systems that aimed to support former slaves in acquiring the skills needed to make them productive, contributing citizens in the absence of the structure of slavery (Giddings, 1984). In addition, public and private systems of education were established for and by African Americans during the post slavery years. Common schools, Sabbath schools and mission schools were founded to meet the growing need of former slaves 
demanding to be educated (Anderson, 1988; Fairclough, 2007; Tillman, 2004a). Zion school was the first all-Black school established in the South in 1865 and was operated with an all-Black teaching and administrative staff (Anderson, 1988; Tillman, 2004a). The establishment of these schools provided many African Americans with the opportunity to function as school administrators solidifying their status as community leaders.

The task of building and maintaining schools catering to Black students was undertaken by African American educators who were functioning as principals of common schools as well as other all-Black institutions (Butchart, 1988; Franklin, 1990; Tillman, 2004a). Not only did these educators assume the task of securing funding and other resources for schools, they bore the primary responsibility of educating the Black community. One such leader was Jeremiah Burke Sanderson who served as principal of the first school for African American children in Sacramento, California which he established in 1856 and went on to head San Francisco's first Black public school in 1864. In Vanessa Siddle Walker's (2000) study of single-race schools in the South during the period from 1935 to1969, she notes that Black male principals were central figures in the community. In this context, the principal served not only as the chief instructional leader, but community representative as well as the liaison to the White community. Rodgers (1967) summarizes that the role of the southern African American 
principal was that of superintendent, supervisor, family counselor, financial advisor, community leader, employer and politician (as cited in Tillman, 2004a).

One such principal who took on various roles was Booker T. Washington. After successfully completing his studies at Hampton Normal and Agricultural Institute, Washington who was interested in practical training and industrial education for southern blacks, was named principal in 1879. In 1881, Washington went on to head the Tuskegee Institute in Alabama where he supervised over 100 faculty members, and served more than 1,400 students. Although Washington abandoned the teaching of basic reading and writing skills for a more trade-based education, he was one of the earliest advocates for the advancement of the Black community through education (Tillman, 2004a).

The research conducted by Siddle Walker (2000) centered on states in the southern United States where African American men held the majority of school leadership positions. Keeping in line with patriarchal tradition, African American women in the south performed comparable duties, however, they were not given the status held by men at the time (Revere, 1985).

One of the earliest African American female school principals was Mary Ann Shadd. Educated early on by Quakers, Shadd went on to become one of a small number of African American women who had the privilege of being formally educated during the post-Civil War era (Beardon \& Butler, 1977). As a young woman, she established a 
school for Black children in West Chester, Pennsylvania in 1840 and taught throughout the northeastern United States before immigrating to Canada. There she became a prominent figure in the Black emigrations movement where she fought against oppressive slave laws like the Fugitive Slave Act, and practices that banned Blacks from attending school restricting them to the most menial jobs (Beardon \& Butler, 1977; Rhodes, 1998). Shadd believed that African Americans should be taught intellectual growth and self-reliance which was counter to the Black Southern ministry and other influential Black educators who touted a vocational and industrial education for African Americans as a way to move toward racial equality. In 1852, she wrote "Notes on Canada West" which attempted to draw African Americans to Canada's promise of freedom and opportunity. With the support of the American Missionary Association, Shadd founded a racially integrated school in Canada that served as a model for both Black and white education. After returning to the United States during the Civil War, Mary Ann Shadd went on to teach for several years in both public and private institutions. In addition, she became the first woman to enter Howard University's law school where she earned a law degree (Beardon \& Butler, 1977; Rhodes, 1998).

Sarah Smith and Fannie Jackson Coppin were two of the most important leaders in the Black community during the $19^{\text {th }}$ century. Their contributions to the progress of African Americans and their involvement in the education of Black children and adults 
are well documented (Franklin, 1990; Perkins, 1987; Tillman, 2004a). Born in 1831, Smith began her career in education as a teacher's assistant at the age of fourteen. In 1854, she went on to teach at the African Free School of Williamsburg. At a time when men dominated education leadership, Smith was appointed principal of Grammar School Number Four and Public School Number Eighty in 1863 becoming the first African American female principal in the New York public school system (Franklin, 1990; Logan \& Winston, 1982). Smith remained in that dual position until her retirement in 1900 when the state of New York abolished legislation permitting separate schools for Black and White students (Lawson \& Merrill, 1983).

Fannie Jackson, one of the most prominent African American educators of the late $19^{\text {th }}$ century, was the first African American woman to hold the official title of school principal. Born into slavery in 1837 , she gained her freedom after being purchased by her aunt at the age of twelve. In 1858, she began studying at Rhode Island State Normal School where she completed her coursework in less than two years. With the financial backing of her aunt and AME Bishop Daniel Payne, Jackson enrolled in Oberlin College in Ohio which was one of the first colleges in the United States to allow for the admission of African Americans and women (Lawson \& Merrill, 1983). While at Oberlin, Jackson enrolled and successfully completed the men's course of study which included Latin, Greek, French and mathematics. During her last two years, she was given the role of pupil-teacher in the college preparatory department. Upon her 
graduation in 1865, Jackson accepted a high school teaching position at the Institute for Colored Youth (ICY), a school for African American students in Philadelphia. In 1865, Fannie Jackson was promoted to principal of the Ladies Department and taught Greek, Latin, and Mathematics becoming the first African American woman to become a school principal. In her 37 years of service at the Institute, Fanny Jackson was responsible for educating more than 5,000 students. Under her tenure, the school produced significant numbers of physicians, lawyers, teachers and principals (Franklin, 1990). More importantly, the school continued to serve as a cultural center for the African American community by offering programs, conferences, and lectures aimed at increasing the social and intellectual position of African Americans (Logan \& Winston, 1982; Perkins, 1987).

In the late $19^{\text {th }}$ and early $20^{\text {th }}$ century, principals and leaders were instrumental in providing leadership to African American communities. Teaching and leading were intertwined with each other and were considered as part of social activism. During this time, African American women educators had a major role to play in these social activities (Siddle Walker, 2003; Tillman, 2004a). The women educators developed a number of self-help programs and women's clubs with the sole objective of improving the lives of Blacks in the United States and beyond (Loder, 2005). In addition, many African American women educators considered it their religious and spiritual mission to advance education and social causes. One such leader was Mary McLeod Bethune. As 
an educator, an organizer, and a political activist, Bethune used her skill and influence to promote education and self-reliance making many contributions to the African American community. In 1904, Bethune established one of the first schools for African American girls in Daytona Beach, Florida. The Daytona Educational and Industrial Training opened with five girls in meager conditions with no equipment and makeshift supplies. In an era when most Black children received little or no formal education, Mary McLeod Bethune worked to secure qualified staff and adequate financial backing to provide for a growing number of students despite seemingly insurmountable obstacles (Holt, 1964). In 1912, she gained the attention of James M. Gamble of the Proctor and Gamble Company, who contributed financially to the school and served as chairman of its board of trustees until his death (Fleming, 1995).

Far surpassing the standards of education for Black students, and rivaling institutions catering to whites, the school grew significantly and merged with the Cookman Institute of Jacksonville, Florida, a school serving African American boys, eventually becoming the Bethune-Cookman College. Bethune served as president of the college from 1923 until her retirement in 1942, a feat only few African America women claimed at the time (Johnson-Miller, 2006). By 1955, the year Mary McLeod Bethune passed, Bethune-Cookman College boasted a faculty of 100 and student enrollment of over 1,000 (Fleming, 1995). In addition to Bethune's success in the field of education, she also became increasingly involved in political matters and fought aggressively to 
end the segregation and oppression confronting African Americans. Her involvement in the White House, working under several presidents, and her affiliation with numerous local and national organizations solidifies her status as a pioneer in Black female educational leadership.

In the years following the Civil War, teachers were needed in high numbers to meet the demands of a growing population of newly freed slaves who were eager for the education they had been denied. Schools in the North and the South were established and operated by African American women who functioned as both teachers and principals (Tillman, 2004; Franklin, 1990; Siddle Walker, 2003; Savage, 2001). Funded by Philadelphia philanthropist Anna T. Jeanes, the Jeanes Supervisors were a group of African American women who served in this dual role as did many other Black women educators of the time. Working primarily in southern rural schools and communities between 1907 and 1967, these women provided educational assistance to black schools by presenting new curricula and instructional techniques, facilitating teacher training workshops, and serving as assistants to school superintendents and county officials (Smith, 1997; Tillman, 2004a). Jeanes Supervisors, like other women serving as school principals, were seen as leaders in their communities, however, their contributions to school leadership remain scarce as topics documented in current research literature (Tillman, 2004). Although the exact numbers of women who served as school leaders during the 19 th and early 20 th centuries remains a mystery, the work of African 
American female principals such as Maria L. Baldwin, Nannie Helen Burroughs, Anna Julia Cooper, Lucy Craft Laney and Virginia Randolph provide some measure of the contribution and knowledge of African American women who served as educators in the $19^{\text {th }}$ century. For instance, Maria L. Baldwin was named principal of the Agassiz School in Cambridge, Massachusetts in 1889. She was appointed master in 1916, one of only two women in the school system and the only African American in New England to hold such a position. As well, Lucy Craft Laney founded and led the Haines Institute in Augusta, Georgia from 1883 to 1933.

Anna Julia Cooper was one among few African American women to get a degree in the $19^{\text {th }}$ century. She was recruited to teach in the M Street School in Washington DC, which was the only Black school in the city. She was named the principal of the school in 1902 (Johnson, 2000; Tillman, 2004a). She accomplished a number of improvements in the field of Black education during her tenure as the principal. She promoted an agenda for Black education which was counter to the one proposed by Washington. As was mentioned earlier, the education program of Washington, consisting of vocational and industrial studies got the approval of influential Whites as the suitable one for educating African Americans. Since the Whites in charge of Blacks' education were convinced of the intellectual inferiority of Blacks, the philosophy of Washington that prevailed was the continuation of the inferior status of Blacks with respect to education. This policy proved as the model for 
educating Blacks (Tillman, 2004). Cooper tried to build and maintain a curriculum and school culture that prepared Black students for collegiate education and beyond. Cooper defied her White supervisor to prepare the students of the school to attend prestigious educational institutions like Harvard, Brown, Oberlin and Dartmouth. As Tillman (2004a) notes, "Her commitment to preparing Black children to attend postsecondary institutions and her refusal to yield to the White power structure and sexist atmosphere in the school and larger community were the factors that led to her dismissal as principal." Review of the tenure of Cooper as principal at the M Street School reveals that African American female educators like Anna Julia Cooper were forced to face many struggles in the form of gender discrimination with respect to their supervisory roles.

Although the contributions of African American female principals are not fully acknowledged in educational leadership literature, their impact on contemporary leaders is apparent. Their commitment to community, innovative spirit and efforts to counter White oppressive structures are characteristics found in today's Black female school leaders. During a time when educating African Americans was a difficult and dangerous endeavor, African American women assumed the task of ensuring that Black students gained the knowledge and experience denied them under the hegemonic structure of a racist American society. African American women were examples of educational excellence and pillars of the Black community for much of the period following slavery 
and into the $20^{\text {th }}$ century. However, with legislation promising to rectify the problems of the nation's system of public education, the leadership of African American females would experience unforeseen consequences.

\section{The Brown Decision and Its Impact on African American School Leaders}

In 1954, the United States Supreme Court handed down its landmark decision in the case of Brown v. Board of Education of Topeka, Kansas. The court unanimously declared that segregated schools were not and could not be made equal, and were therefore, unconstitutional. In previous years, single-raced school systems were the norm with African American students attending schools separate from White students. Many schools districts in the southern states operated under Jim Crow laws that authorized de jure racial segregation in all public facilities under the guise of "separate, but equal." Sanctioned by the United States Supreme Court in the previously litigated case, Plessy v. Ferguson in 1896, the principle of "separate but equal" was given credence and legitimacy. The case involved Homer Plessy, a Black man who brought suit against presiding Justice John $\mathrm{H}$. Ferguson after being arrested and cited for sitting in the White section of a railroad car in Louisiana which violated an 1890 state statute that provided for "separate but equal" railroad accommodations. Implemented for more than 50 years, the practices derived from this Supreme Court decision helped to solidify institutionalized racial segregation and inequality and set the stage for later challenges that demanded the rectification of injustices sanctioned under the law. 
Although the Supreme Court effectively ruled in the Plessy v. Ferguson case that public institutions and facilities were to be divided along racial lines while maintaining equal quality and services, it is well documented that this doctrine only set out to exacerbate the appalling conditions under which many public accommodations for Blacks, including public schools, were found. Schools that were charged with educating African American children often lacked proper supplies and materials, were overcrowded and held in dilapidated, substandard structures. The Brown ruling set out to reverse these conditions granting civil rights to those who had long been denied them. Brown v. Board of Education was a welcomed reprieve from the inequitable circumstances that had divided a nation among racial lines for decades and Black educators celebrated the promise of increased and equal opportunities for both Black students and educators. This anticipation was replaced with frustration and disillusionment as the decision arrived with unforeseen consequences.

One of the unforeseen consequences of desegregation experienced by many African Americans was the demotion and dismissal of hundreds of Black principals and teachers nationwide (Brown, 2005; Hawkins, 1994; Lyons \& Chesley, 2004; McCray, Wright, \& Beachum, 2007; Tillman, 2004a). In 1954, when the Brown v. Board of Education decision declared segregation unconstitutional, 82,000 Black teachers filled the nation's classrooms. Ten years later, the number of African American teachers and administrators dismissed from their positions reached 38,000 (Lyons \& Chesley, 2004; 
Hawkins, 1994). In the state of North Carolina during the period from 1967 to 1970 , the number of Black principals dwindled from 670 to 170 or $75 \%$. In Alabama, the numbers fell 84\% from 250 to 40. Principal positions for African Americans in Mississippi were nearly eliminated with 250 administrative jobs being reduced to practically zero (Brown, 2005; Lyons \& Chesley, 2004; McCray et al., 2007). Tillman (2004b) contends that, the "(un)intended and (un)anticipated consequences" of the Brown decision devastated and negatively impacted the lives on thousands of Black principals and even more African American students.

Although empirical research that address the impact of the Brown decision on Black educators and the motivation behind their displacement dismissed is insufficient, racism, undoubtedly, played a role in how decisions to remove or reassign African American school administrators were made (Lyons \& Chesley, 2004; Tillman, 2004b). After the Brown ruling, many schools catering to an all Black student body were closed and principals dismissed or placed in subordinate positions. It was not uncommon for these positions to be under those of White principals with less administrative experience (Lyons \& Chesley, 2004). Yeakey et al. purport,

Since racial patterns in most communities, especially those in the South[,] did not countenance blacks supervising whites in any capacity, much less teaching, principals of formerly black schools usually were reassigned as assistants to white principals or as central office supervisors. (p. 122) 
A commonly held belief by Whites during this period was that African American principals were not effective leaders of schools responsible for the education of Black students. As Tillman (2004b) points out, during a series of post-desegregation legal hearings, expert witnesses were brought in to testify to this ineffectiveness recommending that all-Black schools be closed and Black principals be replaced with Whites administrators. Additionally, many Black educators were integrated into White schools that retained the majority of their White teaching and administrative staff thus contributing to the diminution of African American leadership (Lyons \& Chesley, 2004; Tillman, 2004b).

African American Female Principals in the Years Beyond Browns

The dearth of African American leadership is not a matter restricted to the years immediately following the Brown ruling. Although the number of African Americans serving in school leadership positions has increased in recent times, their numbers are still relatively small compared to their White counterparts. For African American women in particular, the data show significantly decreased numbers in contrast to men and White women. Gathering data that may shed light on the causes contributing the lack of African American female leadership in the pre-K - 12 system and investigating their leadership practices is essential in resolving this long-standing problem.

Empirical literature that examines the lived experiences and leadership practices of African American female school site administrators, regrettably, is inadequate 
(Allen, Jacobson, \& Lomotey, 1995; Benham, 1997; Bloom \& Erlandson, 2003; Pollard, 1997). Scholars point to the limited number of Black women in school leadership positions as one of the factors contributing to the paucity of research focused on this group of professionals (Benham, 1997; Bloom \& Erlandson, 2003; Tillman, 2004a). In addition, the number of African American researchers exploring topics that affect Black school leaders is limited. The inclusion of African American women within research that merges the experiences of White females and minorities as a whole is also problematic. According to Bloom and Erlandson, posing questions to African American women from the perspective of White women yields unintended outcomes: (a) perpetuating the practice of intellectual and cultural exclusion by creating the appearance of acceptance in women's studies using an ethnic additive model and (b) failing to acknowledge that White women retain White privilege; women of color do not hold a color privilege, thereby making African American women's experiences similar in some ways to women in general but deviant from the White female norm ( $\mathrm{p}$. 344). As a result, the experiences and knowledge of African American female principals is devalued.

Despite the lack of research on African American female principals in the educational leadership discourse, many scholars have examined the lived experiences of African American female school leaders. In a national study of African American school administrators, Doughty (1980) found that women serving as school site 
administrators were more likely to lead elementary schools in challenging urban districts. In addition, Doughty's study identified barriers and challenges faced by African American women in their role as principals in terms of their race and gender. Doughty suggests that for African American women, navigating in a world dominated by Whites and males presents challenges that are gender-based and that are also compounded by race. According to Doughty:

The black female school administrator is in a double bind, perhaps even a triple bind. She embodies two negative statuses simultaneously. One is her color, black, and the other is her sex, female, neither of which society values very highly. (p. 165)

King (1995) also points out, African American women who hold leadership positions in education are often the victims of double jeopardy. Not only do they experience inequity and negative perceptions based on gender, they also experience white-collar oppression as a result of their race. Dardaine-Ragguet et al. (1994) state, "Black women face even more discrimination than Black men since either their gender or their race may evoke negative responses" (p. 405).

Doughty's findings are significant because they focus on the ways in which both race and gender affect the leadership of Black female administrators. Balancing their roles as both women and people of color forces African American women to experience conflict and confront challenges based on their association within each of the 
underrepresented groups. Data on equality of opportunity in educational administration reveals that gender, more than age, experience, background, or skillfulness impacts the position an individual will hold in education (Whitaker, 1990). As well, race more than gender is the major obstruction to professional advancement (Allen, et al., 1995; Singh, Robinson, \& Williams-Green, 1995). Possessing dual identity, Black female principals are largely found in elementary schools that serve low income, underrepresented minority student populations within large urban districts (Pollard, 1997). Their identification as African Americans characterizes them as "saviors" of urban, minority student populations, and their identification as women limits their professional growth into positions traditionally held by men (Bloom \& Erlandson, 2003; Doughty, 1980; Tillman, 2004a).

Other studies of African American female principals explore the impact of their race and gender statuses on their views of themselves in their administrative roles (Bloom \& Erlandson, 2003; Dillard, 1995; Doughty, 1980; Loder, 2005; Pollard, 1997; Reitzug \& Patterson, 1998). Several scholars characterize and define Black female principals as nurturing, thoughtful, compassionate, intuitive and caring (Case, 1997; Dillard, 1995; Loder, 2005; Pool, 1997; Sernak, 2001). Using their cultural consciousness and leadership abilities, African American female principals take on an "ethno-humanist role identity" in their efforts to educate the students they serve (Tillman, 2004a, p 184). Gloria Natham, an African American secondary school 
principal, was the subject of a case study conducted by Dillard (1995) that gave voice to a leadership style that redefines traditional views of effective urban school leadership. Like many other Black female principals, Natham had been given the task of improving a low-performing school that served a predominately minority student population stating that she had been "brought here to clean up this mess and relate to these kids" (Dillard, 1995, p. 545). Natham worked to foster a climate of heightened expectations and increased accountable for improving instruction and increasing student achievement. Low expectations and ineffective instructional practice can become a part of a schools values and norms and can become embedded within the culture, what develops is what Akom (2003) terms an organizational habitus, that is centered around educational oppression and inequality. Natham countered this by continuously nurturing, protecting, and encouraging students and holding herself responsible for their success. Researchers who study the leadership practices of African American school leaders term this "othermothering" (Case, 1997; Irvine, 1999; Loder, 2005). According to Collins (1991) "othermothers" are African American women "who work on behalf of the Black community by expressing ethics of caring and personal accountability, which embrace conceptions of transformative power and mutuality" (p. 132). Dillard's study is an example of African American principals who take on the role of othermothers to positively effect change in urban schools. Dillard labeled Natham's personal 
commitment to students as "authentic leadership": leadership rooted in nurturing and defending children who were not her own.

Loder (2005) utilized interviews to detail the narratives of three African American female principals in the Chicago public school system who came of age during the Civil Rights Movement. According to the author, these African American female principals viewed their role as school principals as being "community other mothers" who nurtured their school communities and felt a strong sense of personal responsibility in ensuring the academic, social and emotional success of their students. Each woman described her experiences with social change, her transformation as a leader and her will to serve her community in spite of the obstacles she confronted. Each served extended tenures in schools surrounded by or adjacent to inner-city public housing that were devastated by poverty, crime, unemployment, and illegal drugs. All of them had devoted their entire careers to working with African American students and families who lived and worked in these neighborhoods. Despite these challenges and others, the women in this study assumed additional roles unique to leading in urban environments adjusting to the needs of their school communities.

Loder maintained that African American female principals used their experiences as mothers to nurture and develop children within the context of school, community and system-wide change. Mrs. O’Neal, a principal who had spent nearly 40 years as a teacher and administrator of a school surrounded by public housing, was one 
of the subjects of Loder's research. Loder described the caring, maternal love and committed practice of Mrs. O'Neal primarily as she illustrated her interactions with students and their families. In her own words, Mrs. O’Neal expressed her commitment and her practice of "othermothering":

I think as a female [principal] I bring motherly love and concern. As a Black woman, I bring it to the Black community because I know that these are our children. I know that I'm connected to them; by the grace of God there go I. It could've been me there. So I bring that knowing that this is a part of me and we're all from one source and that's God (p. 310).

Loder also noted that all three principals views themselves as community othermothers "who were not merely hired to execute a job but rather 'called' to help rebuild [their] communities through acts of nurturing, teaching, and leading" (p. 312).

In a study of African American school administrators, Pollard (1997) investigated how the intersections of race and gender are connected to and play out in the perceptions of African American elementary school principals and their role as urban school leaders. Of the participants in Pollard's study, 12 were African American women whose experience in terms of race and gender differed significantly from Black men. The women served in their roles as principals an average of 5.5 years as opposed to an average of 12 years for male study participants. In addition, Pollard's results showed that although both African American men and women used race and gender in 
their perception of themselves in their roles as principal, Black women, in particular, deemed it necessary to overtly counter stereotypes of African American women as being incompetent leaders. In a discussion of her interactions with staff members at her school, one female participant recounts:

I think people sometimes want to do things differently if you are an African American female. It is difficult in a leadership role as an African American female because sometimes people feel, 'I don't have to listen to that person. I'm not going to take orders from anyone Black.' First, they don't want to take orders from anyone Black. Second, they definitely don't want to take any orders from anybody Black and female. And sometimes you can feel that (Pollard, 1997, p. $361)$.

Pollard contends that African American female principals construct perspectives of themselves in their leadership roles that counter the prevailing perception of race and gender images in the larger society. This form of countering is necessary for African American female school leaders as they continue to encounter and overcome challenges and barriers as they work to meet the needs of a marginalized student population. In addition, offering counter positions provide alternatives to the negative and stereotypical images of African Americans that are predominant in contemporary society. 
Although, African American women were not the specific focus of Pollard's study, the findings offer pertinent insight concerning the ways in which race and gender contribute to their self-perception of their roles as school leaders. Pollard offers three key conclusions that sum up her analysis of African American principals' social constructions of their roles as administrators and, in turn, how they view their work as school leaders: (a) race and gender are integrated rather separate or oppositional statuses, (b) race, gender and, in some cases, class statuses are important not only in terms of self-identity as principals, but also as integral to one's mission as educational leader, (c) although their race/gender status presents a variety of obstacles, taking a defensive perspective was limited. Like Loder, the Pollard study suggests that an African American female principal's ethnic and gender identity shapes the social constructs of her administrative role and defines her mission for schools. As a result, life experiences have a major impact on a person's leadership orientation and it is imperative that the perspectives of Black female school leaders be researched, documented, and included in efforts to improve student achievement.

Bloom and Erlandson (2003) conducted in-depth interviews with three African American female principals leading urban schools. Using narrative storytelling, each principal "recounted the realities (successes, failures, and limitations) of her actual work, the reconstructions of deeply held leadership belief systems, and the personal resolutions evolving from her leadership experiences within schools" (p. 340). The 
researchers chronicle the lived experiences of these leaders as they "struggle for equitable recognition." The authors point out that although there is a paucity of research literature on African American female principals, the emerging literature on this group of leaders suggests that their identification along racial and gender lines differentiate their leadership positions and experiences from their male and White female counterparts. Like Pollard (1997), the researchers attempted to listen to the voices of African American female principals as a way to allow them to construct their own definition of what it means to be a Black female urban school leader.

Each woman described her reality in terms of race and gender, and her resolve to thrive regardless of the challenges and obstacles she faced in an attempt "to unmask and scrutinize the power of racist and sexist practices operating within public school systems" (p. 352). Working in urban schools, all three principals were challenged to meet the need of low-income, minority student populations in the face of programs and policies that hindered their success. Having similar lived experiences to the students they serve and a cultural connection to the community, these women were able to draw upon their "cultural consciousness" to inform their leadership practice (Bloom \& Erlandson, 2003, p. 359). Possessing a strong self-image and cultural identity allowed participants in this study to challenge the commonly-held notion that urban schools, with all of the accompanying challenges, are destined to fail. The study also found that their identification as African American women also facilitated their ability to counter 
the hegemonic discourses and practices that typically oppress urban school communities. As student populations become more ethnically and economically diverse, and as social changes and technological advances make the task of leading urban schools progressively more complex, the authors maintain that drawing on the experiences of veteran school principals is essential in providing direction for future administrators (Bloom \& Erlandson, 2003; Pollard, 1997; Tillman, 2004a).

\section{Theoretical Framework}

Black feminist theory and critical race theory grounded this study and served as the frameworks for exploring the experiences and perspectives of African American women elementary school principals. The lived experiences of Black women in elementary leadership positions are unique and, therefore, it was important to identify a theory that reflects the social location of the participants in this study as Black and female.

Black Feminist Theory

The oppression of the thoughts, experiences and perspectives of African American women in research and education literature continues to serve as a mechanism that challenges their economic, educational, political, and social renewal. Those who choose to examine the lives of Black women in this country continue to search for methodological approaches that focus on countering traditional methods that maintain white and male-dominated power structures (hooks, 1984; Patton, 1990). One 
framework that is useful in examining the lived experiences of African American women is Black feminist theory. Black feminist theory seeks to lift African American women from their marginalized status to the center of all areas of society. This marginalization is regarded as what Collins (2002) deems the "outsider within" status, in which African American women have been considered worthy enough to hold leadership positions, but they remain outsiders because they are still seen as insignificant by the dominant group, having no voice outside of their affinity group. Collins posits that because a sense of equality cannot exist without a personal or cultural connection between the experiences of African American women and the dominant group, it is important for the ideas "produced by Black women that clarify a standpoint of and for Black women" be heard (p. 468).

Collins (2002) outlines three key themes in her theory of black feminist theory. The first theme of self-definition and self-valuation suggests that theoretical frameworks are shaped and produced by the lived experiences of African American women as told by African American women. In her second theme, Collins proposes that the individual stories and experiences of African American women are distinctive, but at the same time move between and among the experiences of other African American women. Lastly, Collins proposes that although there are commonalities among African American women, the intersectionality of age, religion, class, and sexual orientation add to the complexity of their collective experience and forms a basis for which the 
experiences of African American women can be uncovered and understood (Collins, 2002). The aspects of Black feminist theory that are most germane to this study are the relationship between race, gender and leadership and the use of voice in the construction of one's identity.

As the literature validates, the investigation of school leadership from the perspective of African American women has been limited at best. Collins (2000) asserts that, "the overarching theme of finding a voice to express a collective, self-defined Black women's standpoint remains a core theme in Black feminist theory" (p. 110). Proponents of Black feminism reaffirm Collins' assertion that the stories of African American women need to be told by Black female voices (Davis, 1981; hooks, 1981; Lorde, 1984). hooks (1981) also maintains:

No other group in America has so had their identity socialized out of existence as have black women. We are rarely recognized as a group separate and distinct from Black men, or as present part of the large group 'women' in this culture. When Black people are talked about, sexism militates against the acknowledgement of the interests of Black women; when women are talked about racism militates against a recognition of Black female interests. When black people are talked about the focus tends to be on black men; and when women are talked about the focus tends to be on white women (p. 20). 
Black feminist theory emphasizes the power of self-definition and addresses the importance African American women to be the voice of their own experiences, thoughts, ideas and perspectives. This self-definition leads to self-valuation which is key to moving Black women out of the clutches of subjugation into the realm of social justice and equality. Black feminist theory purports that domination functions not only through structures of power that operate from top down. However, systems of oppression also use the energy of those on the bottom to perpetuate continued oppression. Members of marginalized groups internalize negative stereotypes propagated by the master narrative in order to maintain White power and privilege. Thus, Black feminist theory encourages individual empowerment and social transformation as a means of countering hegemony and marginalization as one's definition and value of self determines how African American women, as a group, manage negative perceptions within the work environment and larger society (Collins, 2000). According to Collins, "Because self-definition is key to individual and group empowerment, ceding the power of self-definition to other groups, no matter how wellmeaning or supportive of Black women they may be, in essence replicates power hierarchies" (p. 36).

The individual stories and experiences of African American women are distinctive and provide Black women with a unique perspective on Black womanhood that is unavailable to other groups. It is impossible for those who are not Black women 
to fully understand and, therefore, interpret the experiences and perspectives of Black women as the intersection of race and gender place them in an exclusive position within society. Intersectionality was first purposed by Kimberle Crenshaw in 1989 when she described the various ways in which race and gender interact to shape the multiple dimensions of Black women's experiences. According to Crenshaw, the experiences of African American women intersect the boundaries of black/male and white/female positions of domination (Crenshaw, 1995). Intersectionality also provides a historical context for which African American women have struggled to resist negative stereotypes and racist practices. Collins (1998) explained, "Intersectionality thus highlights how African American women and other social groups are positioned within unjust power relations, but it does so in a way that introduces added complexity to formerly race-, class- and gender-only approaches to social phenomena" (p. 205).

The voice of Black women is many, and the call to raise those voices is counter to the master narrative that articulates one voice for Black women in America. To validate the various experiences and perspectives of African American women, Collins proposes a concerted focus on black women as agents of knowledge as they are solely authorized to inform theoretical knowledge based on their experiences (Collins, 1998). Self-definition, self-valuation and voice enables women to reject external control of their representation and creates self-empowerment, independence and confidence in their position as Black women in a White male-dominated society. 
The theoretical foundations of Black feminist theory focus on the interrelation of race, gender and class and their impact on the status of the African American woman as the "outsider within." The use of self-definition, self-valuation and voice creates a space that allows African American women to oppose structures that contribute to their oppression. Like Black feminist theory, critical race theory also seeks to counter the stories told by the dominant culture and give voice and credence to the experiences of African American women and other peoples of color.

\section{Critical Race Theory}

Critical race theory (CRT) focuses on the perspectives of those members of society who are often victims of oppression and racist practices. Derived from the works of Derrick Bell and Alan Freeman, critical race theory emerged from Critical Legal Studies (CLS) which sought to uncover and confront how American legal policies worked to sustain hierarchical relations of power and oppression in the midst of the post-Civil Rights era (Bell, 1992; Crenshaw, Gotanda, Peller, \& Thomas, 1995; DeCuir \& Dixson, 2004; Delgado \& Stefancic, 2001; Matsuda, 1991). Although CLS interrogated power structures and relations within the space of law, CRT focused the discussion of race from the margins to the center by challenging historical understandings of the law as racially unbiased, objective and neutral. Moreover, critical race theorists sought to critique the laws and policies that sustain white hegemony in the United States. Matsuda (1991) describes the initial function of CRT as: 
The work of progressive legal scholars of color who are attempting to develop a jurisprudence that accounts for the role of racism in American law and that works toward the elimination of racism as part of a larger goal of eliminating all forms of subordination. (p. 1331)

To this end, CRT scholarship focuses directly on race and racism by locating the interests of people of color at the center of examination to advance racial equality, in general, and equal treatment under the law, in particular (Cook, 1995; Crenshaw, 1995; Dalton, 1995). Crenshaw et al. (1995) proposed that critical race theory, "aims to examine the terms by which race and racism have been negotiated in American consciousness, and to recover and revitalize the radical tradition of race-consciousness among African Americans and other peoples of color ... " (p. xiv).

CRT scholars commonly operate under the following central tenets (Bell, 1992; Crenshaw, et al., 1995; Delgado \& Stefancic, 2001; Harris, 1995; Matsuda, 1991): (a) interest convergence, (b) the permanence of racism, (c) whiteness as property, (d) counter-storytelling, and (e) the critique of liberalism. Working from these tenets, CRT as theory provides a rich framework for understanding the lived experiences of people of color. Here, I use critical race theory as a theoretical framework through which to explore and examine the relative subordination of African American women in elementary school leadership positions and how racial inequality may be reproduced through common policies and practices within the pre- $\mathrm{K}-12$ education system. 
Although Ladson-Billings and Tate (1995) are credited with introducing CRT to education research as a powerful theoretical and analytical framework, researchers have yet to fully utilize CRT in this capacity (DeCuir \& Dixson, 2004; Ladson-Billings \& Tate, 1995). As DeCuir and Dixon point out, “[e]ducational researchers have commonly focused on counter-storytelling and the permanence of racism and have yet to focus on the other aspects of CRT" (p. 27). To add to the body of research that explores and documents the experiences of those whose stories are often told through privileged discourses, three central tenets will be used as an analytic lens through which to examine the experiences and perspectives of African American female elementary school principals.

My use of CRT acknowledges the existence of racism and racist practices in American society, whiteness as a means to garner and access privilege, and the use of counter-narratives to resist dominant ideology that perpetuates deficit theorizing. First, CRT is based on the notion that racism is a common component of American societal structure and that these structures govern all social, political and economic realms. Under this view, "liberal democracy and racism in the United States are historically, even inherently, reinforcing; American society as we know it exists only because of its foundation in racially based slavery, and it thrives only because racial discrimination continues" (Bell, 1992, p. 10). The way in which race and racism are inter-mingled within the U.S. social order highlights the complacency of American citizens when it 
comes to sustaining racist practices and inequality. Since racism is considered as a permanent fixture of American way of life, those who want to fight for racial equality and social justice, take serious efforts to expose the racism prevalent in all its dimensions (Crenshaw, 1988; Solorzano \& Yosso, 2001).

The notion of whiteness as property is based on the premise that simple being White affords one certain rights and privileges not offered to others. Cheryl Harris (1995) explores this phenomenon in her article "Whiteness as Property" where she states:

Whiteness defined the legal status of a person as slave or free. White identity conferred tangible and economically valuable benefits and was jealously guarded as a valued possession, allowed only to those who met a strict standard of proof. Whiteness - the right to white identity as embraced by the law - is property if by property one means all of a person's legal rights. (p. 280) Laws in the United States protect the property of whiteness and affirm White privilege throughout all aspects of society. The institution of slavery essentially established a racial hierarchy and the construction of racial identity. The property of whiteness guarantees a certain level of respect, the right to own property and not be owned as property, and the right to determine who can be property.

Lastly, the use of counter-storytelling allows for the challenging of dominant discourses which is a departure from the mainstream legal scholarship as it integrates 
the experiential knowledge of people of color. Counter-storytelling seeks to legitimize and validate those experiences in what Taylor (1998) describes as "a form of oppositional scholarship" which challenges the "experience of Whites as the normative standard and grounds its conceptual framework in the distinctive experiences of people of color" (p. 122). These counter-stories are also an integral part of analyzing and understanding racial inequality. Taylor (2004) states CRT is concerned with "issues of race, class and gender [and] are inextricably bound by economic, social and political hegemonic power structures" ( $\mathrm{p}$ 35). CRT thus is a means of communication available to people of color as a means of narrating their experiences and realities in the form of storytelling.

Use of CRT, with respect to African American school leaders in general, and African American female elementary school principals specifically, underpins their encounters with race and gender as the central focus. Such encounters represent a shift from the traditional leadership perspective of looking at masculine and feminine leadership from different angles. CRT makes use of the real life stories and experiences of African American women principals, which challenges the discourse and beliefs of the dominant viewpoints of white supremacy especially in the context of the education of poor and minority students. CRT focuses on the acknowledgement of the role that race has played in the schools and society and seeks to establish policies to ensure that 
individuals who have been historically sidelined, based on their racial identification, are provided with equal access to the available opportunities (Bell, 1992).

The Intersection of Black Feminist Theory and Critical Race Theory

Black feminist theory and critical race theory formed theoretical bases for investigating the lived experiences of African American female elementary school principals as a group operating on the margins of society. Marginalized groups and dominated groups have used narratives as a means of resisting discriminatory and exclusionary practices in society. According to Delgado (1989), storytelling is a powerful means for creating meaning as well as challenging myths. Both critical race theory and black feminist theory underscore the importance and significance of storytelling and narratives as a means of "contradicting the Othering process" and resisting subjugation (DeCuir \& Dixon, 2004, p. 27). Laurence Parker (2003) proposes that,

Critical race theory treats racism as a normal, ingrained element of political and legal structures rooted in historical and social circumstances, uses narratives and storytelling to highlight how persons of color experience the world and racial oppression, challenges assumptions that White European American experience is the norm, and questions the belief that law is intended to create an equitable, just society. (p. 152) 
Black feminist theory utilizes the stories of African American women specifically as told by these women as a vehicle of empowerment by giving the silenced voice. By engaging African American women in the production of narratives about their own lived experiences, they become active co-creators of knowledge. As Duren (2002) writes,

Breaking silence is the process by which African American women seek to reclaim their humanity, by giving new meaning to their own lived experiences, in a system that gains part of its strength by objectifying Black women. It represents a breaking through into the public arena of what African American women have talked about to each other in private... Giving voice serves as a metaphor for Black women's political activism. It references the collective quest for self-definition and self-determination. The term voice authenticates individual experiences and links these experiences to larger systems of social power (p. 3)

This reinterpretation and authentic description of the lived experiences of African American women and its impartation to the world broadens the knowledge base and serves to act as a critique of oppression.

\section{Conclusion}

School leadership has transformed greatly in recent years. Certain groups, in particular, face increasing challenges as they strive to improve student learning. Schools 
exist in a society plagued by gender discrimination and racism and it is within this context that female and minority administrators must navigate to achieve success within their roles as leaders. "Administrators who are women, white and of color, are struggling to find their own voices as they bring their unique heritages to the bureaucracy of schools" (Gardiner, Enomoto, \& Grogan, 2000). Because women are often seen as nurturing and concerned with relationships, they are typically not thought to hold the inherent characteristics seen as prerequisite to leadership (Harder \& Waldo, 1983). For minority women, particularly African American women, navigating in a world dominated by white males presents challenges that are gender-based and that are also compounded by race. According to King (1995), African American women who hold leadership positions in education are often the victims of double jeopardy. Not only do they experience inequity and negative perceptions based on gender, they also experience white-collar oppression as a result of their race.

The purpose of this literature review was to present the evolution of African American female leadership and the contributions of Black female school leaders to the fabric of the American educational institution. The first section provided a historical reference for the contributions of African American school leaders. As history reveals, African Americans have long-standing experience in the struggle for racial, political and economic justice. The dynamics of race, power and privilege continue to play a role in the lived experiences of African Americans in the education system. The second 
section uncovered how all three dynamics work individually and collectively to influence subjugation and exert domination. The review also examined the present experiences of African American women in school leadership and their efforts to educate the nation's marginalized groups in a system filled with practices and policies that counter their mission. A review of Black feminist theory and critical race theory represent perspectives that deviate from mainstream ideology in terms of school leadership and African American women. Essential to both of these theoretical thought is that the voice of the silenced must be self-defined and heard. 


\section{Chapter Three: Research Method}

\section{Introduction}

This study gives insight into the lives and experiences of a select group of African American female elementary school site leaders within an urban setting as they work to provide quality educational experiences to our nation's youth. The leadership experiences of Black women at the elementary level have the potential to be of great value to the field of education contributing to our understanding of the complex nature of leading some of our nation's most challenging institutions of learning. Until recently, these contributions have remained obscured amongst education research that focuses primarily on the experiences of White women and minorities in general (Tillman, 2004a). Although there are several studies that examine the principalship, the perspectives and experiences of African American female school site leaders in particular have not been thoroughly investigated (Bloom \& Erlandson, 2003; Quinn, 2002; Tillman, 2004a). Smith-Campbell (2002) maintains that "the dearth of research on Black principals weakens the body of research in educational administration because it thus fails to acknowledge the significance of gender and race in educational leadership" (p. 2).

This research bridges this gap in the literature by gaining a perspective on the lived professional and personal experiences of African American women school site leaders at the elementary level using a qualitative approach combined with the principle 
of counter narrative. A qualitative research method was chosen for this study because it allows for the discovery and understanding of complex phenomena within their natural setting, often told through the lens of those involved in the experiences (Bogdan \& Biklen, 2008). According to Bogdan and Biklen (2003), "qualitative research is an approach to social science research that emphasizes collecting descriptive data in natural settings, uses inductive thinking, and emphasizes understanding the subjects' point of view" (p. 261). In addition, the qualitative research method is also often utilized by researchers belonging to groups that have traditionally been marginalized by society, or who are examining the experiences of those who have been excluded from full participation in mainstream society because this method allows research participants to offer counter stories to the narratives that dominate research and diminish their value as authentic contributors of knowledge (Bogdan \& Biklen, 2008).

\section{Research Approach}

In designing this study, I borrowed from the tradition of narrative inquiry and method to aid me in understanding the lived experiences, personal meaning, and perspectives of a select group of Black female education leaders. Narratives are stories or accounts of events, experiences and encounters. They allow for the report and description of individual and collective experiences, and give the reader an open door to the lives of individuals through which to walk leading to increased understanding of motivation and feelings. In qualitative research, narrative inquiry is used to document 
the stories of individuals as a way of revealing, informing, and constructing meaning from lived experiences. According to Connelly and Clandinin (1990), "The main claim for the use of narrative in educational research is that humans are storytelling organisms who, individually and socially, lead storied lives. The study of narrative, therefore, is the study of the ways humans experience the world" (p. 2).

This study also employed the philosophical underpinnings of critical race theory and Black feminist theory within the use of biographical narrative inquiry to allow readers a window into the lives of African American female elementary school site administrators and make meaning of the stories. Critical race theorists promote the use of storytelling as an important element in qualitative research (Connelly \& Clandinin, 1990; DeCuir \& Dixson, 2004; Gloria Ladson-Billings, 2003; Solorzano \& Yosso, 2002). Using storytelling as a methodological tool allows researchers to "counter" the stories of deficiency often told for and about marginalized groups. Critical race theory posits that marginalized groups can narrate their own stories and that these stories can shift the definition of normalcy and what is true. Critical race theorists are also concerned with how society reproduces hegemonic systems and structures, and seeks to oppose these systems using counter-storytelling. In their article, Unwritten: young women faculty in educational leadership, Sherman et al. (2010) write, "What follows are our narratives. We offer our voices with the desire of uplifting ourselves, coming to know ourselves and one another better, and allowing others a window into who we are 
and what we have experienced as young women professors of educational leadership" (p. 744). Similarly, this study seeks to offer the voices of Black women elementary school leaders as contributing members to the education leadership knowledge base.

Black feminist theory is another philosophical foundation that promotes the use of storytelling on which this study was based. Black feminist theorists also use storytelling to promote self-authorship in an effort to shape Black female participation in and responsibility to the Black community within the context of White, mainstream America (Tillman, 2002). According to Collins (2002), “Our experiences as African American women provide us with a unique standpoint on Black womanhood unavailable to other groups" (p. 47) My desire to elevate the voices of African American female elementary school principals through the lens of Black feminist and critical race theories validates my choice to use the narrative inquiry method for conducting this study. As Bloom and Erlandson (2003) state, "Listening to the voices of African American women's lives in leadership may begin to change minds and social constructs about the 'Others' in America's public school districts” (p. 352).

\section{Procedures}

This qualitative study used a narrative inquiry approach to investigate and explore the perspectives, experiences, challenges and facilitators of African American female elementary school principals. This section includes a detailed description of the six participants in this study as well as the data collection process. 


\section{Participants}

Purposeful sampling was used to identify participants for this study because current data bases of school administrators are not disaggregated by race coupled with gender. As an African American principal in a large urban district, I had regular contact with other Black women working as school site administrators at the elementary level and informed them of my intentions to conduct the study. At the same time, I reached out to colleagues in other districts who recommended women for participation. Fourteen women in three districts were contacted by email and sent a letter of introduction (Appendix A) explaining the study and soliciting their participation. After one week, I contacted these women by phone as follow up and to answer any clarifying questions. This process took approximately two weeks as the women were busy in their roles as school site leaders. Eventually, six principals agreed to participate in the study and to which statement of consent forms (Appendix B) and demographic questionnaires (Appendix C) were sent via email.

The six participants included in the study were African American females serving as principals of elementary schools in two urban school districts in the greater San Francisco Bay Area. Inclusion criteria used to identify and invite subjects to participate in this study were as follows:

1. Participants must identify themselves as African American and female. 
2. Participants must currently hold a position as elementary school principal in an urban school district.

3. Participants must have held their position for at least one full year.

Participants must be available and willing to participate fully in the research study.

\section{Description of the Participants}

The principals selected for the study represented a purposeful sample of African American elementary school administrators in terms of location, setting and size of district. Six school site leaders from two districts in the San Francisco Bay Area participated in the study. Principals led schools in two districts reporting a minimum of 30,000 ADA. All participating principals held their positions for at least one full school year with total administrative experience ranging from 2 to 12 years. Participating principals all had at least 5 years of classroom teaching experience and were selected based on their identification as African American and female, and their positions as elementary school principals in urban settings.

Participants in this study ranged in age from 37 to 56 years of age. All of the principals were married at the time of the study with two of the women having two adult children each, three women each having two school-aged children and one participant with no children. All of the principals hold bachelor's degrees and five hold master's degrees in Educational Leadership. All of the participants lead schools with diverse student populations with two principals leading schools with dual language 
immersion programs. Table 1 presents a summary of participants' demographic data gathered from the questionnaire and interview discussions. Student demographic data describing the schools headed by each of the principals in this study are outlined in Table 2. Table 3 represents a summary of the ethnic makeup of teachers of the schools discussed in this study.

Table 1: Demographic Data of Study Participants

\begin{tabular}{lllllc}
\hline Participants & Age & $\begin{array}{l}\text { Educational } \\
\text { Background }\end{array}$ & $\begin{array}{l}\text { Marital } \\
\text { Status }\end{array}$ & $\begin{array}{l}\text { Socio-Economic } \\
\text { Background } \\
\text { (Growing Up) }\end{array}$ & $\begin{array}{c}\text { Administrative } \\
\text { Experience } \\
\text { (Years) }\end{array}$ \\
\hline Marsha & 3 & BA, Adm. Cred. & Married & Working Class & 5 \\
Christine & 9 & BA, MA & Married & Working Class & 12 \\
Michelle & 6 & BA, MA & Married & Middle Class & 12 \\
Lauryn & 4 & BA, MA & Married & Middle Class & 4 \\
Amel & 7 & BA, MA & Married & Working Class & 2 \\
Kelly & 8 & BA, MA & Married & Working Class & 6 \\
\hline
\end{tabular}

Chart adopted from Spicer, 2004

Table 2: Student Demographic Data of Schools Lead by Study Participants

\begin{tabular}{|c|c|c|c|c|c|c|c|c|c|}
\hline Principal & API & $\begin{array}{l}\text { African } \\
\text { Amer. } \\
\%\end{array}$ & $\begin{array}{l}\text { Latino } \\
\%\end{array}$ & $\begin{array}{l}\text { Asian } \\
\%\end{array}$ & $\begin{array}{l}\text { Pacific } \\
\text { Islander } \\
\%\end{array}$ & $\begin{array}{l}\text { Filipino } \\
\%\end{array}$ & $\begin{array}{l}\text { White } \\
\%\end{array}$ & $\begin{array}{l}\text { ELL } \\
\%\end{array}$ & $\begin{array}{l}\text { Free/ } \\
\text { Reduce } \\
\text { Lunch } \\
\%\end{array}$ \\
\hline Marsha & 811 & 19.9 & 15.0 & 45.2 & 1.1 & 6.4 & 10.5 & 20.2 & 58.8 \\
\hline Christine & 710 & 83.0 & 7.8 & 2.0 & 5.1 & 1.2 & 0.8 & 4.7 & 78.1 \\
\hline Michelle & 891 & 11.0 & 23.7 & 47.5 & 1.3 & 5.4 & 10.7 & 15.8 & 31.3 \\
\hline Lauryn & 753 & 27.5 & 28.1 & 15.7 & 1.7 & 3.5 & 23.5 & 26.4 & 63.2 \\
\hline Amel & 644 & 72.2 & 15.8 & 7.7 & 1.4 & 0.9 & 1.1 & 14.6 & 100 \\
\hline Kelly & 701 & 76.9 & & 1.1 & 15.7 & & 0.7 & 3.5 & 85.1 \\
\hline
\end{tabular}


Table 3: Teacher Demographic Data of Schools Lead by Study Participants

\begin{tabular}{lllllll}
\hline Principal & $\begin{array}{l}\text { African } \\
\text { American } \\
\%\end{array}$ & $\begin{array}{l}\text { Latino } \\
\%\end{array}$ & $\begin{array}{l}\text { Asian } \\
\%\end{array}$ & $\begin{array}{l}\text { Pacific } \\
\text { Islander } \\
\%\end{array}$ & $\begin{array}{l}\text { Filipino } \\
\%\end{array}$ & $\begin{array}{l}\text { White } \\
\%\end{array}$ \\
\hline Marsha & 10.5 & 10.5 & 31.6 & & & 47.4 \\
Christine & 5.9 & 5.9 & 5.9 & & & 82.3 \\
Michelle & 4.6 & 9.8 & 17.5 & & 2.8 & 65.3 \\
Lauryn & 6.3 & 6.3 & 12.3 & & 6.3 & 68.8 \\
Amel & 18.2 & 4.5 & 4.5 & & 4.5 & 68.2 \\
Kelly & 29.4 & & & & 5.9 & 64.7 \\
\hline
\end{tabular}

\section{Marsha Anthony}

Marsha, age 53, grew up in a working class family in the southeast section of San Francisco. She along with her five siblings attended Catholic school and acknowledges that her parents and grandparents placed a high level of importance on education. "My parents valued education, but my grandparents really valued education because they came from the Jim Crow days," she stated. Although education was a priority in her household, Marsha was the only one of her sisters and brothers to attend and graduate from college. Marsha went on to marry and has two adult children ages 19 and 22 .

Marsha began her career in education as a special education paraprofessional where she reported gaining valuable experience working with special needs children. Soon after, she obtained a position as an elementary advisor where she reports witnessing changes in family structure and providing non-traditional resources. She comments, "During that time, when a lot of crack babies were just coming into schools, 
a lot of grandparents were raising their grandchildren, and the grandparents were tired and didn't have any resources. We had to find what they needed. It was a learning experience." During this time, Marsha attended a local university where she worked on obtaining her teaching credential. After being certified, she became a classroom teacher and has been in her current position as principal of Fannie Jackson Coppin Elementary School for the past 5 years.

Coppin Elementary is located in working class neighborhood of a large urban center and one of many dual language programs in the district. Coppin's student enrollment is reportedly 267 students in grade kindergarten through fifth grades. Student demographics include 45.2\% Asian, 1.1\% Pacific Islander, 6.4\% Filipino, 15.0\% Latino, 19.9\% African American, and 10.5\% White; 20.2\% of students are classified as English learners and 58.8\% are designated as economically disadvantaged. Of the 19 staff members classified as teachers, demographic data show $31.6 \%$ Asian, 10.5\% Latino, 10.5\% African American, and 47.4\% White. Student achievement scores at Coppin have been steady over the years with the school reporting an Academic Performance Index (API) of 811.

\section{Christine Anderson}

A wife and mother of two school-aged children, Christine, 49, always knew she wanted to be an educator. After tutoring a young boy in her neighborhood, she worked to become a teacher. Christine grew up in a working class section of District 1 and 
attended its public schools from kindergarten through high school. The child of a teen mother, Christine explained how her family encouraged her and expected her to move on in her education. She comments, "I had to go to college. In our culture, when you go, you're going for everybody. My mom had me as a teen, so she couldn't go. So, I was the next one to carry the torch because she couldn't." She went on to earn a bachelor's degree and got a position with the school district in early childhood. Shortly after, she obtained her teaching credential and worked for 9 years as a kindergarten teacher. Christine went on to earn a master's degree in special education and worked as a teacher on special assignment for 3 years before being persuaded by her supervisor to pursue a position as project manager in the district's early childhood education department. Her position as a project manager landed her at Leola M. Harvard Elementary School, where after 8 years of working alongside the administrator, she became principal.

Harvard Elementary School is located in a predominately African American, working class neighborhood. Although the area has experienced some gentrification over the last 10 years, the schools in the area remain largely African American in terms of student population. Student demographics at Harvard Elementary include 2.0\% Asian, 5.1\% Pacific Islander, 1.2\% Filipino, 7.8\% Latino, 83.0\% African American, and $0.8 \%$ White; $4.7 \%$ of students are classified as English learners and $78.1 \%$ are designated as economically disadvantaged. Of the 17 teachers on staff, demographic 
data show 5.9\% Asian, 5.9\% Latino, 5.9\% African American, and 82.3\% White. Harvard's student enrollment is 256 students in grade kindergarten through fifth grades. Student achievement at Harvard has increased over the years with the school reporting an Academic Performance Index (API) of 710.

\section{Michelle Mwelwa}

Michelle, at age 56, is the only African American elementary school principal who leads a school without a significant Black student population. She is a wife of 30 years and mother of two adult children. She grew up in a middle class family in the city in which she works (District 1) and acknowledges that her mother being a teacher influenced her decision to pursue a career in education. Michelle obtained her bachelor's and master's degrees from local universities. She is one of three children and credits her family with encouraging her and her siblings to earn advanced degrees. Michelle began her professional career as a pre-k teacher. After earning her teaching credential, she spent 18 years as a classroom teacher and the last 12 years as principal of Anna Julia Cooper Elementary School.

Anna Julia Cooper Elementary is located in middle class neighborhood and is also a dual language program in the District 1. Cooper's student enrollment is reported at 501 students in grade kindergarten through fifth grades. Student demographics include 47.5\% Asian, 1.3\% Pacific Islander, 5.4\% Filipino, 23.7\% Latino, 11.0\% African American, and 10.7\% White; $15.8 \%$ of students are classified as English 
learners and $31.3 \%$ are designated as economically disadvantaged. Of the 28 staff members classified as teachers, demographic data indicate $17.5 \%$ Asian, $2.8 \%$ Filipino, 9.8\% Latino, 4.6\% African American, and 65.3\% White. Student achievement data at Cooper Elementary have grown with the school reporting an Academic Performance Index (API) of 891.

\section{Amel Lewis}

Amel, a 2nd year principal at Sara Smith Elementary School, is a 37 year old wife and a mother of two pre-teen boys. Although her parents divorced when she was young and her family struggled financially, Amel remembered her mother instilling in her the importance of getting an education. She comments, "My Mother has always been an inspiration to me. She would always tell us that our education is truly our own." She spent 8 years as a classroom teacher before becoming a school site leader. Amel was the first in her family to attend and complete college and she eventually earned two master's degrees, one of which led her to educational administration. Smith Elementary School is her first administrative position.

Smith Elementary School is located in a predominately low-income area surrounded by three federal housing units. The area experiences frequent bouts of crime and violence and efforts to combat unemployment have been futile. Student demographics at Smith include 7.7\% Asian, 1.4\% Pacific Islander, 0.9\% Filipino, 15.8\% Latino, $72.2 \%$ African American, and 1.1\% White; $14.6 \%$ of students are 
classified as English learners and 100\% are designated as economically disadvantaged. Of the 22 teachers on staff, demographic data show 4.5\% Asian, 4.5\% Filipino, $4.5 \%$ Latino, 18.2\% African American, and 68.2\% White. Smith Elementary's student enrollment is reportedly 349 students in grade kindergarten through sixth grades. Student achievement at Smith Elementary has been uneven and with the school Academic Performance Index (API) currently standing at 644.

\section{Lauryn Henderson}

Lauryn, age 44, is the principal at Mary Shadd Cary Elementary School and has been in this position for 2 years and is a wife and a mother of two young children. She was raised in a two parent household where both parents held professional jobs. With her mother being a teacher, Lauryn thought it only natural that she travel down the same path. While serving 12 years as a classroom teacher, she earned her master's degree in educational leadership. Lauryn held the credential for several years before her husband suffered a career altering injury which forced her into administration because of financial necessity. She reflects, "It was by circumstance that I found my way to administration." She spent a year as vice principal of an elementary school until funding strains eliminated the position. Categorical funding allowed her to be hired as an instructional coach, a position she held for one year before arriving at her current position. 
Mary Shadd Cary Elementary School is located in working class neighborhood and has a diverse student population. Shadd Cary Elementary School's student enrollment is reported at 345 students in grade kindergarten through sixth grades. Student demographics include 15.7\% Asian, 1.7\% Pacific Islander, 3.5\% Filipino, 28.1\% Latino, 27.5\% African American, and 23.5\% White; $26.4 \%$ of students are classified as English learners and $63.2 \%$ are designated as economically disadvantaged. Of the 16 staff members classified as teachers, demographic data show $12.3 \%$ Asian, 6.3\% Filipino, 6.3\% Latino, 6.3\% African American, and 68.8\% White. Data trends show declining student achievement with the school reporting an Academic Performance Index (API) of 753.

\section{Kelly Smith}

Kelly, 38, is the principal of Nannie Helen Burroughs Elementary School and has over 14 years of teaching and administrative experience. Raised in a two parent household to teen-aged parents, Kelly was always successful in school. She grew up and attended school in a working class neighborhood and attended neighborhood schools from kindergarten through twelfth grade. The older of two children, Kelly is the first to attend college and earn a degree. After undergraduate school, she tried a career in sales, but was laid off when the company lost an important account. Working in an after school program moved her to return to school in pursuit of a teaching credential. A classroom teacher for 7 years, Kelly expressed her desire to move into administration. 
She reflects, "After being in the classroom and having much success with my students and their families, I wanted to do more. I was giving workshops for teachers and administration just seemed like a natural progression.” Kelly entered a master's program and earned a degree in educational leadership. Three years later, was married and became an elementary school principal.

Nannie Helen Burroughs Elementary is located in a working class neighborhood and is bordered by low-income housing units. Student demographics at Burroughs Elementary include 1.1\% Asian, 14.9\% Pacific Islander, 0.4\% Filipino, 6.0\% Latino, 76.9\% African American, and 0.7\% White; 3.5\% of students are classified as English learners and $85.1 \%$ are designated as economically disadvantaged. Of the 17 teachers on staff, demographic data show 5.9\% Filipino, 29.4\% African American, and 64.7\% White. Burroughs Elementary's student enrollment is 282 students in grade kindergarten through fifth grades. Student achievement at Burroughs Elementary has increased over the years with the school reporting an Academic Performance Index (API) of 701.

\section{Data Collection}

In an effort to capture the authenticity of their voices, qualitative methods in combination with a demographic questionnaire and was used. The primary source of data collected in this study were comprehensive 60-90 minute interviews with six African American female elementary school principals regarding their personal and 
leadership experiences in terms of their race and gender identity (See appendix D for interview questions). Interviews were conducted in various locations. Three interviews took place at restaurants. Two interviews were conducted at the participants' office. One interview was done by telephone. All interviews were transcribed and forwarded to each participant for member checking. Each participant was asked to review the transcription data for accuracy, and allowed to modify, clarify or delete any information.

Confidentiality and privacy were maintained by storing digital recordings of interviews on a password-protected computer. Transcribed interview data was also stored in secure computer files. Each principal was assigned a pseudonym for the purposes of this study and the districts in which they work identified as District 1 and District 2. School names were also given fictitious names; however, school demographic and test score data remain authentic.

Other data sources used in this study included a questionnaire to gather demographic data and school demographic information. The research took place during the 2010-2011spring semester in selected San Francisco Bay Area school districts.

In an effort to evaluate the trustworthiness of the data, member checking was used as a tool to confirm the accuracy of the interview transcriptions. Participants were sent a copy of the transcripts and asked to verify its correctness. No changes or corrections were identified by the participants. Secondly, any researcher biases and 
assumptions that influenced the study were documented in a field notebook and identified in the study.

\section{Data Analysis}

As Bogdan and Biklen (2008) maintain, data analysis occurs before data is collected and continues throughout much of the qualitative research process. The analysis process largely involved coding and memoing whereby the data was coded, categorized and analyzed to arrive at an interpretation of the findings that articulates the experiences and views of African American female elementary school site leaders. According to Jorgensen (1989):

Analysis is a breaking up, separating, or disassembling of research materials into pieces, parts, elements, or units. With facts broken down into manageable pieces, the researcher sorts and sifts them, searching for types, classes, sequences, processes, patterns or wholes. The aim of this process is to assemble or reconstruct the data in a meaningful or comprehensible fashion (p. 107). My data analysis began with reviewing participants' responses to interview questions. As a novice researcher, I reviewed the transcripts several times to familiarize myself with the flow of text and recorded my initial impressions of the responses. I developed a matrix containing interview responses on which I wrote words and phrases that represented particular topics and patterns. These words and phrases were used in the development of an initial coding and indexing system. Charmaz (1983) states, 
"Researchers use codes to pull together and categorize a series of otherwise discrete events, statements, and observations which they identify in the data" (p. 112). These codes aided me in categorizing the data as patterns and themes began to emerge.

As the analysis continued, I reviewed the questionnaire data, field notes and observation data and emerging themes were modified accordingly. After identifying themes, the matrix previously developed was enhanced to include observation and questionnaire data. In addition, I identified segments of each source of data paragraphs, sentences and phrases - and they were color coded and assigned to a specific theme.

\section{Role of the Researcher}

As an African American female elementary school principal in District 1, I had pre-established collegial relationships with half of the research participants. Although I had no previous relationship with the remaining participants, I did feel a sense of kinship and connection with them. As a researcher, I attempted to limit my bias in execution of this study; however, having such close relationships and common identification with the participants, preconceived ideas and views did surface. When I first began my study, 1 took with me all of my biases and preconceptions of school leadership, the status of elementary school principals, and leading schools as a Black woman. I found it difficult to refrain from inserting myself into the discussions and to possess a sense of objectivity. During both the interviews and observations, there were 
times where I struggled with remaining solely in my role as researcher. Forcing myself to take a more reflective role, I provided a forum for these women to express the joys and frustrations of their lives as school leaders.

The participatory nature of the study, however, did allow me to gain greater trust and openness during the guided discussions. Thus, participants appeared to feel very comfortable expressing their thoughts, ideas and feelings in terms of race, gender, and class, and how they influence their leadership. As the primary researcher, I took on the exclusive responsibility of collecting both interview and observation data. My insider's perspective allowed me to capture the standpoint of Black female elementary school principals as they openly and honestly contributed their voices to field of education leadership.

In this chapter, I described the data collection process and method of analysis used in this study of African American female elementary school principals as well as my role as the researcher. This chapter also presented a detailed portrait of the participants in addition to demographic data describing their student and teacher populations. The chapter that follows presents the narratives of the six principals included in the study analyzed through the lens of Black feminist and critical race theories. 


\section{Chapter Four: Report of Findings}

\section{Overview}

The purpose of this chapter is to offer a valuable glimpse into the lives of six African American female elementary school principals who are charged with educating diverse student populations in urban settings. The women in this study perform various roles in their positions as school site administrators and community leaders. Being an African American elementary school principal, I was naturally interested in the experiences of my colleagues not only to validate my own success and struggles, but to collect and document these experiences as they may serve as foundation for increased understanding and support of a group of leaders who are often overlooked or misunderstood. Initially, participation in this study was limited to African American women who lead schools with predominately Black and Latino student populations. Upon further consideration, however, my choice to include African American women who lead schools in urban districts not considering student demographics or school performance was based on my belief that all of our experiences are valid and worthy of examination. As a result, participant responses were evaluated to satisfy my intellectual curiosity to the following questions:

What are the personal and professional experiences of African American female elementary school principals? 
What are challenges faced by African American women in their roles as elementary school leaders?

What supports do African American female elementary school leaders utilize and require in order to improve teaching and learning in urban schools? Each participant described her journey to the principalship as well as her lived experiences as a female elementary school site leader. Because of my relationship with most of the participants and my insider's perspective, the interviews were conducted as conversations rather than sterile and cold interrogations. My goal was to provide a space for these women to comfortably tell their stories - openly and honestly. These stories serve as a means of challenging the discourses of the majority and giving voice to a group occupying the margins of society. Critical race theorists and proponents of Black feminist theory use counterstorytelling to reveal and critique hegemonic dialogues that perpetuate and sustain racial stereotypes and racist practices. By engaging in counterstorytelling, the experiences of six African American female elementary school principals leading urban schools are documented and exposed as valid contributions to educational discourse. Furthermore, by voicing their counter-narratives, the dominate discourses that are often found in the education realm are confronted and the perspectives and experiences of Black female school leaders moves from the depths of subjugation to the light of equality and liberation. 
The chapter presents the counterstories of each African American female elementary school principal presented in Chapter three as they relate to the stated research question and secondary questions. The results highlight the experiences of these women and are organized six main sections according to the questions used to guide discussions during the data collection process. The first section describes how the participants began their careers in education and who encouraged them to further their own schooling. The next section presents the various roles of the principalship in the context of their race and gender as described by the participants in this study. The third section describes the principals' views of how their race and gender influence where they are assigned as school site leaders and their opportunities for promotion. The fourth section presents the participants' perceived challenges and barriers as they relate to race and gender. The following section details how these school leaders define success in their positions. Lastly, the final section describes coping and support mechanisms used by the women to persist in their roles as elementary school principals followed by a summary of the findings. Figure 1 shows the way in which the participants past experiences, personal practices and leadership experiences interrelate to tell a story of how these leaders function as African American women in their roles as elementary school principals. 


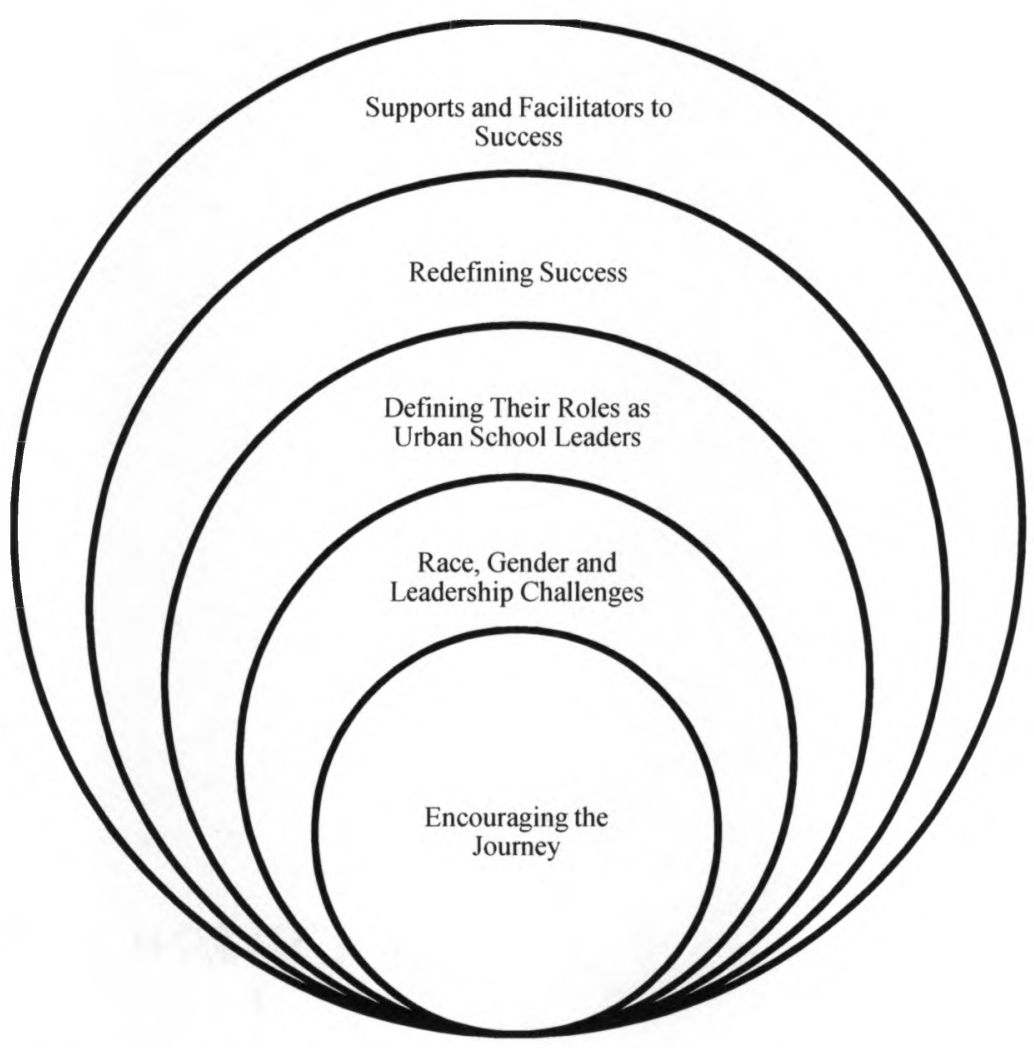

Figure 1. Interrelationship of Personal and Leadership Experiences

\section{Encouraging the Journey}

Each conversation began with participants being asked to describe their journey to the principalship and identifying the people in their lives who have had the greatest impact on their decision to pursue careers in education. Although the paths to educational leadership may have been different for each principal, the support from family to further their education was universal. Historically, African Americans have valued schooling and encouraged the pursuit of literacy among members of the Black community. According to Siddle Walker (1996) traditional expectations for acquiring 
knowledge for African Americans offered no choice between "'learning and not learning'; failure to learn was 'unacceptable to teachers, family, peers and community"' (p. 3). For the women in this study, the impact of family support and encouragement on their educational and professional success was significant.

Christine, the first in her family to complete college, drew attention to the centrality of family amongst African Americans and recognized the cultural value of achievement in the Black community. Her experience is one of feeling as if she had a responsibility to her family and her people to succeed and was supported in doing so. She stated:

So, from the beginning I always knew I wanted to be an educator, that was from eighth grade. I had an experience where I tutored a little boy and I knew right then that I wanted to be a teacher. I think the impact on my education was really that experience I had with that youngster when I was 13 years old. I got to see the power I had and how you can make a difference. My grandmother and my mom [encouraged me] to go to school. Just all of them saying, you're going to go to college. They hadn't gone, so it didn't go as far as what are you going to major in. But, as long as I can remember college was instilled in my mind - 'and then you'll go to college, and then you'll go to college.' When you go to $6^{\text {th }}$ grade, you go to $7^{\text {th }}$ grade. It was natural. When you left high school, you go to college. So, I think with both of them having not gone to college, it wasn't, 
'You'll major in this, 'it was, 'You'll go to college.' I was first generation. My mom and grandmother didn't have the experience to tell [me] how to navigate; they just wanted me to get there. I think culturally that's who we are and from day one it was never a question, you're going to go. It was a whole family mantra. So when I come to work, I come with all that. I have to do very, very well because everybody sacrificed. I don't know if it's all of our stories but for a lot of us, that's our story. I have to perform because I'm carrying a whole people and I have to represent. I think I feel more strongly about that doing the work that I do. I have to stand up tall every day - looking at all these little faces from the children to their parents and grandparents.

Marsha who was the only one of her siblings to attend college also benefited from the support of her family and the importance placed on achieving academic success. She described how her family's experiences with racism and prejudice shaped how they inspired her to further her education. She commented: My parents valued education but, my grandparents really valued education because they came from the Jim Crow days. My grandmother said she would get a book and she would open up her book, be interested, [and] the whole middle section of the book would be gone. That's how things were in school in the south. You know, it was separate and not equal, and so my grandmother always valued education. So did my grandfather. They basically helped our parents put 
all of us through school. I would say my grandparents, and my parents also, were really instrumental in making sure that we valued education.

Marsha's comments speak to the resilience and strength of African Americans in terms of their historical relationship with the nation's education system. Marsha's grandmother and her experience with the inequities of America's education system influenced the degree to which she encouraged Marsha to pursue her education. This value of education and the pursuit of knowledge is not often associated with African Americans, however, Marsha's story clearly shows the value that African Americans place on acquiring knowledge.

Amel's decision to become a teacher was also rooted in her experience growing up in a household where education was valued and the pursuit of education well supported. When answering the question, Who had the greatest impact on you to pursue a career in education?, Amel pointed to her mother as the central figure behind her academic and professional success. She stated:

My mother, my mother, my mother. My parents divorced when I was really young but it was always a part of my mom's upbringing. She went to Catholic school and you know, she came from a well to do family, but we struggled with her being a single parent. We had our trials and tribulations and we were just about homeless at one point, but the one thing she never ever strayed from was the significance and importance of an education. And no matter what, that was 
the key because that meant opportunity as opposed to being limited in your choices. That's what I want to provide for my students.

Unlike Amel, growing up in a two-parent, middle-class household provided Lauryn with knowledge and experiences that helped guide her on her educational and professional path. What remained constant, however, was the heavy reliance on family for support in achieving both academic and career goals. Lauryn explained how important family support and the privilege of access were to her and her efforts to become a teacher. Her comments are an example of how she not only benefited from the encouragement of her family, but how she and her family leveraged their social capital to ensure academic success:

My mother is an educator and it's interesting, growing up her career was not glamorous to me. Having a mother for a teacher is kind of like being a preachers kid, you know, it represented to me a lot of work, we were always stumbling over papers that she was correcting, but what I was most impressed by as I got older was that she had so much time for her family and she was able to advocate so well for us as students. My parents sort of provided this lifestyle that many people with professions can have access to certain things that really gives them a step ahead because with her being an educator, we knew other teachers and they were just always challenging me to see what I was doing academically and what I was producing. Stuff that students would have to pay 
for like seminars, the route to college and how to get there; it was just an everyday conversation for us. So, high expectations and academic achievement were just as common place as making sure that you had napkins at the dinner table or that you ate vegetables every night or that you brushed your teeth. Education was supported. My family really kind of put into perspective that whole thing about your education was something that was never... that no one can ever take from you. My mother, being a teacher, we knew her story - how she became an educator. So you just kind of had a life map on how you're supposed to go. If I hadn't become a teacher, I wouldn't be as successful at something else. I learned through conversations and my parents modeling for me what it is that you're supposed to do.

For these women, family served as motivators and supporters - encouraging them to attend college, pursue advanced degrees, and pursue careers in education. The importance of encouragement from others was again expressed by the women in this study in their discussion of what led them to their positions as school site administrators. Encouragement is defined as the act of inspiring, instilling confidence, promoting or advancing. These supportive relationships and the encouragement received by the principals in this study were particularly important because they influenced the participants' decisions to either become school leaders or remain in their positions as classroom teachers. Tharenou's (2001) study found that, unlike men, 
women advanced to supervisory positions when they reported having been encouraged by colleagues or supervisors. For African American women, the encouragement of others is particularly important because of their marginalized position in society which has influence on their confidence, self-esteem and self-worth. The fact that all of the women felt they needed encouragement from others in their profession to advance in their careers, speaks to the importance of community and supportive relationships to marginalized groups in American society. Christine's comments are an example of how career encouragement impacted her decision to pursue a career in educational administration:

It was an administrative position that became available in the early childhood department, and the director called me and said, 'I want you to apply. 'I was about 32 or 33. I was like, 'Oh, I'm too young. I can't do it. But, I did it and that's how I became an administrator.

Marsha came up through the teaching ranks as a paraprofessional. After entering a teacher credentialing program and serving as a classroom teacher and literacy coach, She explained how she was encouraged into administration by two female school leaders who served as mentors. For Marsha, without this support a career as a school leader would have not been considered. She commented:

I think that the person who had the biggest impact... When I was first hired at Coppin, I met Valerie Mims and we really hit it off. We really had a good 
relationship and she saw something in me that I didn't see in [myself], and she continuously pushed me to do more, to do better. She continuously recognized what I did and validated me. She always validated me and you know, that was just wonderful coming from another African American woman who I can look up as like a big sister. So, it was just really wonderful how she embraced me and really, really taught me a lot of things about being a good leader. The other person who really pushed me forward was Carol Porter (who was principal of the school at the time) because Carol saw something in me that I didn't see in myself, too. So, when she was going to go ahead and retire, she really started grooming me and getting me ready for the job.

Amel also benefitted from the encouragement of others in her quest to move into educational administration and have a greater impact on the lives of the students she served. Like Marsha and Christine, the persistent persuasion of others gave her the confidence to pursue an administrative career. She stated:

I think that for me, I actually had a couple of mentors who were principals who said to me probably about, maybe four or five years ago, you need to be looking at getting into administration and I blew it off. I loved being in the classroom, I loved teaching. I saw [being a principal] as definitely, you really have to have a lot of stamina and really have to... I felt like there had to be this great preparation to make that happen. So, I had just finished with my first masters 
and [someone from a principal preparation program] came and she said, 'Can I observe your class?' She said something to [my principal] about me entering the program and I was like, 'oh wow, uh uh.' Then another person said something to me about it who works also in the same district and this is probably about three years later, 'You should apply.' Then I actually started thinking about it, 'Ok, I'm going to apply. 'And I have to say, it took me 'til the $11^{\text {th }}$ hour to go, 'Ok, I'm going to do it and I made my teaching tape and went for it. But, I think as I was in the midst of this journey, I think I started looking at like, being a teacher I felt like I'm giving back to my community, I'm supporting and I'm taking what was given to me and I'm passing that torch on to my babies and I would tell them, steal all the knowledge that you can from me because now you're going to stand on my shoulders and build up from where I've stopped. This, where I am, you're going to go further than I am and I think I took that and thought about now I could take this to another level to affect change that's happening on campuses and that's one way that I was looking at administration. This is an opportunity for me and looking at how I then wanted to be great but, also be more effective than I probably could be just in the classroom. Michelle, too, enjoyed being in the classroom and was not looking to move up into administration when she was approached by colleagues who encouraged her enter a newly developed educational administrative program. She reported: 
Well, I really had no intentions of being a principal. I loved teaching. I was going to follow my mother's footsteps and just retire after teaching for 40 years like she did. Then I ended up where I was always mentoring other teachers, and they kept saying, 'You're a natural, you naturally mentor,' and I didn't see that as being something that meant I should go at a leadership position. So, I continued to do that and then an opportunity opened up where USF and the school district established a relationship that lasted for two cohorts and I was part of the first cohort where I actually went through the process just to satisfy the people who said that I should do it. I went to the information meeting and so, and then the principal at the time kind of initiated this. He was like, 'You need to do this. You always substitute for me. You're a natural and you need to go ahead and go for this.' And some of the other teachers said it, too. Although Michelle initially did not have much confidence in her leadership abilities, others did. For her and the other women in this study, the journey to school leadership was one that involved replacing self-doubt with self-assurance. As Lauryn stated:

A new principal came and he was very well trained and had a specific vision for the school and was really into like school reform and standard-based instruction and he was probably the first one that approached me and said, you know, you should consider being a principal. I guess it was based on his classroom visits 
and things that I said in the staff meetings, and how I got along with the community and other teachers.

In summary, the avenue by which the principals in this study took to educational leadership may have been different for each of them. However, each principal acknowledged the support they received from family to further their education as key in laying the foundation for their careers in educational leadership. Their success and level of support, as highlighted by their responses, was not contingent upon the educational history or lack of educational success of their families. Their stories serve to redefine the dominate view of the relationship between the Black family and education. These stories suggest that the African Americans family plays an integral role in the promotion of the educational success of its members. Also, of significance, is the encouragement these educators received from others professionals as it was key in promoting their advancement to school site leader. These stories, like so many other stories told by "silenced voices," are counter to the individualism of the dominant ideology that maintains that one's success is a result of their own individual initiative.

\section{Race, Gender and Leadership}

In recent years, there has been a gradual shift in the demographics of the principalship with more and more Black women heading schools particularly at the elementary level (Tillman, 2004a; Pollard, 1997; Bloom \& Erlandson, 2003). Despite this increase, little is known about the Black women in their roles as elementary school 
site leaders in urban districts. Given their positions, the African American women in this study experienced race and gender related leadership interactions that impacted how they navigate in their roles. When asked to reflect on the ways in which their race and gender influences their work and how others perceive them and their performance, these women spoke passionately about their membership as African American and female in relation to their position as leaders. As Christine offers, "I think that for the people in my community my race and gender say a lot. I think it says to them that I can do this as well. That's important considering how neglected our community is." Much of the discussion on this topic, however, centered primarily on placement and career advancement, and the need to prove their professional worth to others. Below are the participant's responses separated into two categories - Placement and Career Advancement, and Prove Yourself.

\section{Placement and Career Advancement}

Four of the six women in the study cited placement and career advancement as being heavily influenced by their race and gender. Several studies have found that Black women in the elementary principalship are more likely to head challenging schools in urban districts with predominantly Black student populations (Tillman, 2004a; Doughty, 1980; Bloom \& Erlandson, 2003; Pollard, 1997). Researchers have also found that women at the elementary school level are less likely to advance to higher positions such as superintendent. Their placement coupled with the lack of promotional 
opportunities highlights how racism is embedded within social structures of domination including educational institutions. Christine commented on what she described as "the hidden message" being communicated to not only African American female school leaders, but the district as a whole:

Ifeel like I have to go above and beyond to get everything right because sometimes the expectation is that I'm not going to do it or it's going to fall short. I don't know many African American principals, maybe one or two in elementary, that have a principalship outside of this community. So, I'm thinking, is the perception that I can only handle children who are in my community? Would you allow me to go to West Providence (an affluent school on the opposite side of the city)? Would you place me at Langley (an affluent school on the opposite side of the city)? Do you think that I'm only as good as here? Although it's not blatantly said, when I look around to see where are the other principals who look like me, where are they placed? The majority of them are placed in low performing schools. Do you think I'm only a good enough principal to operate in this setting? When I take inventory, I know of only one principal who's not in this community. All but one of the Black women [principals] in this district are at schools in this neighborhood. "Seven out of eight, right? So, I'm good enough to go here, but am I good enough to go anywhere in the district? It's like a hidden message, you haven't said it but, you 
haven't given me the opportunity. Nor have I seen it with my colleagues. People of other races are commonly moved into and out of schools in this community. People do it all the time, but we haven't been asked to move schools. I look at practices of my district. African American principals will stay in the African American community. I haven't seen any different. But I've seen other folks come into the schools, get their experience and move other places.

Lauryn also expressed what she perceives as a trend of men and Whites advancing in their careers from challenging urban elementary schools to central office positions or secondary school positions. She stated:

Men, for some reason, Black or white, tend to be promoted or moved to higherpaying positions in middle schools or high schools. White women don't stay in elementary schools, too long, at least not in the harder neighborhoods. I was just talking to a colleague of mine about possibly moving to a middle school position. If I did move, it would probably be in a similar neighborhood. I could to a central office position, too. I like curriculum and instruction, but how many of us have moved into central office positions? Not very many. I can't even tell you who from elementary school that was a Black women is in central office now. It seems like [elementary school] is our niche. It's in somebody's head that this is all we can do. 
Kelly, who articulated her desire to pursue a position as superintendent, offered her perspective on how race and gender has influenced her professionally and how others perceive her:

I think people see us as urban elementary school specialist. You know, once we 're here in this position. We can't do anything else. That's how I think race and gender has influenced me and how others see me in this position. Maybe they think our skill set doesn't translate to other areas. Problem-solving, team building, instructional knowledge, content knowledge, leadership skills, I mean, I guess those skills are only useful at inner-city elementary schools. When people think of elementary schools principals, they think of this motherly type, and to White folks motherly is not strong. Whereas if you're Black, mother runs the show. So, in this white and male world, it doesn't pay much to be a Black woman.

Amel, who like Kelly, has desires of advancing professionally, commented on the lack of career advancement for African American women at the elementary level in her district. Although she acknowledges that race and gender play a role in this trend, her commitment to the students at this level seems to outweigh her desire to be promoted. She commented:

I've heard that Black women don't go beyond elementary school principal in this district. So, I guess, race and gender, even class, has repercussions in terms 
of how you advance here. I mean, it's a shame. Why would you want to even start at this level, if you're a young Black woman. You know, I didn't have any intentions on being a principal before I started this job, but I can't see myself doing this until retirement. Because I look at what's going on and what's happening to these children in these schools and I want to do more. You only have so much power as an elementary school principal. I do know that.

\section{Prove Yourself}

Three of the African American principals expressed a concern for being perceived as incompetent by professional peers, classroom teachers and parents based on their racial and gender identity. Research has shown that African American women have felt as though they have had to prove themselves to be accepted by their white peers, and that their decisions are often second-guessed (Gates, 2004; Carver, 2002). This is an inherent result of racist stereotypes in American society which declare African Americans and women as less that capable. For African Americans, the term black tax has been used to describe the way in which Black people have had to perform at levels much higher than Whites to achieve acceptance (Gates, 2004). The women in this study experienced not only a black tax, but a female tax when interacting with their school communities. Lauryn discussed how her race and gender have hindered her progress as a leader: 
I think my race and gender have caused a longer period of getting to know you between my staff and myself. I think with any new principal there's sort of like a pledging period where the teachers are trying to figure out are you friend or foe and where your alliances are and I think for those of us who are African American, it just takes a lot longer. It's as if they're looking for you to match up with their own preconceived notion of who you are and so some of us might match up immediately and others of us might not be who they perceive [us] to be. So, the present fear lasts a lot longer and I know that sounds cryptic but, my colleagues who are not African American seem to not have the same struggles as some of us who are - like a longer period of time where you have to prove yourself or trying to get things implemented. Things will take longer because they had a longer period that they don't know you. It's the same conversations we've been having about student achievement where there's a theory that says that when the teachers, when we look at our white students, the teachers are predominantly white and students are predominantly white, they seem to get down to business of teaching and learning quicker because they have this cultural understanding with one another. So, they don't go around misunderstanding certain nuances or trying to figure out why did he say that or what does that mean. You know, there's not just physical... where when you mix the two, it's like this, it takes longer for you to get to the academic portion 
because you're still trying to figure out the cultural piece, and you don't have as much time with instruction and students don't do as well. So, it's kind of the same thing playing out. I might decide to say, 'We need to do..., we need to look at how..., we need to look at our parent communication, how we communicate with parents and I might go around and around the tree. We might go around and around and around and around where as somebody else who's white might say the same thing and they immediately have more buy in.

Marsha discussed how race and gender has affected her in her role as an elementary school principal and how she attempts to deal with negative behaviors: The first thing that people see is an African American. I decided that my black is beautiful and that I'm extremely strong and I can do what anyone else can do. So what seems to be the challenge to me is that people sometimes judge you, or they don't sometimes, a lot of times, people will judge you by the color of your skin and not the content of your character. That still bothers me. I think that one of the hardest things is just to get people to see you as a person but, you know, that's never going to happen when you're in African American skin. They're always going to look at you as being African American first. Ifeel with the children, the children are fine, the children are my least worry. But, when it comes to parents and when it comes to parents within certain socioeconomic groups, I think sometimes it can become a challenge. You're looked at in a 
different way and even though you're extremely knowledgeable, they think that they may know more than you know. They don't value you're expertise. You've got to feel like you're valued, feel like your expertise is valued. Don't get me wrong, it's not all parents but, the ones who don't value you are the ones who stay in your mind. You know, the ones that you're constantly thinking about, why? Why do I have to prove myself to this person, you know, when I know what I'm doing in this role. But I continuously have to prove myself and after a while, it just gets to be draining.

In her discussion of regularly held meetings for elementary school administrators, Michelle reflects on the contrasts between the dialogues of Black and non-Black administrators. She stated:

Their (non-Black principals) struggle is more logistics. Like they'll be mad about, 'Oh, you know, we don't have enough money and the state is not supporting our endeavors to do blah, blah, blah.' Where the African American ones are still fighting with people not respecting our authority or not respecting our intelligence or not respecting our number of years of experience or not being compliant with us just by virtue of the fact that we're black. We constantly have to prove ourselves. So it's like, it just takes longer to get things done. It's more stressful. 
In summary, when asked to reflect on the ways in which their race and gender impacts their work and how others perceive them and their performance, three of the principals reported that their performance was viewed as substandard as a result of their racial and gender identity. Four of the six women in the study pointed to their racial and gender identification as significant factors in where they are assigned as school site leaders and their prospects for promotion to more influential positions within the field of education. Although African American women hold school leadership positions in increasing numbers, their placement in elementary schools which have the lowest rates of advancement when examined through a critical race theory lens is an example of the persistence of racism and the ability of the dominate group to use their Whiteness as property in this society. Giving African American women the perceived power of elementary principalships, but relegating them to these positions with limited control and influence is another form of oppression and economic domination. Black feminist theory maintains that African American women must speak out against this oppression and name racist practices by being the authors of their stories. Injustices are allowed to take place because the master narrative conveys a distorted view of society and as a marginalize group, African American women need to be the voices of their own narratives and expose hidden injustices and covert racist practices. 


\section{Challenges and Barriers to Success}

Although each of the participants shared the view that several barriers existed within the context of their school settings that posed challenges to their ability to effectively educate students and support teachers, they pointed to negative stereotypes and racial identity as the most significant obstacle to their work as leaders. The women all shared stories of not being valued by their peers and teachers as competent leaders, and occupying an "outsider" status within their respective institutions. When asked to describe some of the barriers and challenges to their positions as African American female elementary school principals, each principal described a situation where race or gender was an obstacle to them in their positions as school leaders. Each woman's story suggests that racism, more than sexism, is perceived as a powerful means of discrimination in their professional lives. Describing how race influences her leadership functions as a result of how other perceive her Michelle stated, "It doesn't matter how educated you are. If you're Black, you are at the bottom of the bottom. There is no equal. There is no individuality. You are your color and Black is bottom." She goes on to comment:

When I send out a memo, you know, it's really not that deep. It might be a couple of sentences, but they're looking for syntactical errors. I'm like, 'Do you think I'm going to have drums playing in the background?' What's going on with that? It just wears you down. You look at another principal down the road 
who's not Black, and they're quiet when [they] talk about stuff. They don't have these little racist experiences that wear you down.

Marsha describes a situation that many principals in her district may face with the influx of language immersion programs. Heading a Mandarin -immersion program, she asserted:

I don't speak Mandarin and I'm not going to learn to speak Mandarin. I know some words and can learn some words but I'll be 50 years old next year and it's a language, it's not visual and it's very auditory and I'm just not an auditory learner, so it's not going to work but I do speak children and teachers and so that has been something that's been challenging because the people who are interested in Mandarin programs don't look like me so they want to know how am I able to be an administrator at a school with the Mandarin program. Parents aren't trusting my expertise because you don't speak their language and they don't speak mine. And I don't look like them either, you know, but I have a few students who look like me who are in Mandarin class and speak Mandarin but my job, it's not to speak Mandarin. My job is to produce some of the best teachers that I can produce, to basically introduce my teachers to some of the best teaching practices, find a way for my teachers to know the importance of forming relationships with children and you know, making sure that children are successful and that children, each and every child in that school is looked at as 
an individual and recognized as an individual and has a voice and so that's my job. My job is not to speak Mandarin, and I don't speak it, and I'm all right with that. The children speak it and they're fluent so that's what we want, right? I don't think, [Dave] had this problem with the Mandarin program at his school. Everyone talked about how wonderful he was. He didn't speak Mandarin, but he was a white man, so there you go. It's interesting how hard we work as Black women to get where we are, and then work hard in our positions, only to be looked down upon, not valued, and second-guessed.

Christine expressed having to constantly prove her professional value as being a barrier to her success and the success of her students. She described an incident where her expertise was second-guessed:

I remember when I led a workshop on guided reading. Now, I'd taught guided reading lessons every day when I was in the classroom and had prepared for this workshop and had my lesson plans together and I'd worked with a group of students beforehand. After leading the workshop I got a lot of push back from the teachers because they thought it was impossible to do three guided reading groups in an hour and so forth. Two weeks later, I brought in a district trainer, who happened to be White, for another workshop on the same topic and she said the same thing I said two weeks earlier. Of course, there was no pushback. 
Everyone thought it was such good information, and of course, no one said they couldn't do three groups in an hour.

Christine went on to describe how she feels the need to constantly increase her content and instructional knowledge so that she is not perceived as incompetent by teachers and staff. She stated, "Not knowing what I'm talking about or being able to practice what I preach is a sign of weakness, and as a Black woman in this position, I have to know more and do more than anyone else would or could."

Similarly, Kelly poignantly described her frustration with constantly having to prove her ability to other professionals. Her feelings are indicative of how African American women struggle in their positions as leader as they negotiate issues of race and gender:

My goal is to be an excellent leader by virtue of how well my students perform and enjoy their time in school. I mean I clearly realize that, you know, I'm privileged to be a part of their academic history because I remember every single last teacher and principal that I had. The fact that I am black and educated, and cute on some days if they let me get some rest, is secondary you know. But, I don't know if I'll be allowed to reach that goal or even come close. I just, I didn't become a principal by fluke, you know. I have studied hard. I have been strategic and smart, and I'm capable and I'm respectful and I think that given the opportunity that I'm also a person that can help people realize their 
dreams because that's what I think is part of being an educator given this opportunity. Black women in these positions, we're not an obscurity. We're not, you know, that one who made it. We work hard just like everyone else. So, I think, how I'm perceived by others and what they think they know about me is definitely a barrier.

Lauryn discusses her impatience with the current system that she views as counter to her goal of educating poor and minority children at high levels. Her words highlight her struggle with continuing in her position and her commitment to her community. This battle weighs heavily on many African American women as their culture posits a view of Black women that is steeped in the notion of strength in the face of insurmountable odds.

I don't see myself doing this for much longer. It's like where would be my next step, or I would move schools because it is... you know the racism partnered up with the ignorance that I deal with ... in an educational institute. That's the part that is so frustrating. Some teachers and staff just cannot be reformed. They just need to be removed from the building. In our district, in particular, the teachers' union is the strongest I've ever seen. You can't do a thing to them and it doesn't matter how much harm they do to Black children. I mean they would really have to do something egregious. They'd have to shoot a child, and you'd be like, 'Oh, Ok. Let me start the progressive disciple process. Here is your verbal warning, 
'You will not choke that child again.' You will refrain from putting your hands on a child between the hours of 8 and 3.' It's nuts. That wouldn't happen in a middle-class White school and a Black women, that's a slap in the face. I find myself negotiating constantly. And when you talk to people outside of your profession and tell them what you deal with they say, 'Oh, you need to call the police. You need to do A, B and C, and I'm like, 'No'. Then I'll be out. If you show the aggression, then people come and they escort you from your desk. It may not be that immediate, but when you're transferred somewhere, you're not behind that desk. It's like you have studied for years to get to this place and the people you have access to have just stumbled across the job. You don't get to pick them. They're not the best and the brightest. They're just there. So, you're just trying to train everybody... those with a minimal level of competency. And they have the nerve to question your expertise and your knowledge. This is crazy. There is no other structure of employment that exists like this. This is ridiculous.

Kelly expressed her frustration with the education system, and also sees the lack of support of African American students as a barrier. She asserted:

The 400 children I'm supposed to be leading, that fuels my ability to lead. The barriers have been that I take what I do personally, and I want everybody else to, too. It's hard for me to accept that not everybody cares about Black children 
like I do. I want what's best for all children and I can't imagine me wanting any different. So, a challenge for me is working in a system that doesn't support and value - truly value children of color, and if you're Black you're really in trouble. The system itself wasn't designed to educate everyone at high levels and that's a problem for me, you know, working in this system. If we know what children need, then there shouldn't be a problem providing it. It's like being pledged. If you've ever been in a sorority, it's like being hazed. We just happened to be gettin' paid for it.

Amel expressed the lack of support for schools located in blighted neighborhoods as a major hindrance to her success as a leader when charged with educating urban youth. She stated:

Ifeel there is a whole part of my job that has to do with social services. I feel like I serve the community but, some I have to serve a lot more than others and I don't get the resources I need to do that. I feel that the children who are in poverty are basically not valued as they should be valued. And, parents want the best for their kids, so we can't blame them. This job is so complicated and so complex that it's the type of job that keeps you awake at night. You know, just constantly thinking about what's the next thing that's going to happen. I think about my kids who come to school late because the parents can't put them on the school bus because there was a shooting in the neighborhood the night 
before. They don't feel safe with the kids going out because retaliation could be happening. You have to think about things like that. It's not that the parents want their kids to be truant. They're just trying to keep their kids safe, and so there are a lot of things we deal with in our schools that they don't in other schools. We need resources, like all schools need resources, ours just has to look different and no one's recognizing that. They just think because we 're Black and care about our kids, we can deal with it, we can make things happen and we do. But just imagine what could happen for our kids if everybody made things happen. Not just the Black principals, the women at that. We can only do so much. This job consumes you and at some point you ask, 'Who am I? What is my role? Who am I responsible for?' The fact is, we are responsible for our community, for our people. I'm getting tired just thinking about it. Next question. (Laughs)

Similarly, Christine discussed the lack of resources for school serving challenging schools serving poor and minority students and identified some of the ways in which she feels the education system has been a detriment to Black students and other underrepresented minority children. She maintained:

We don't have adequate resources. Our schools have different needs, and if the district truly wants to close the achievement gap then we would all have things like APs to help us support our new and underperforming teachers. We would 
get full-time counselors, nurses, librarians, and parent support clerks. We would have reading specialists to support our children who are reading below gradelevel and coaches for new teachers. The need for our schools is that great and if the district really wanted our students to achieve, then they would provide us with what was necessary to make that happen. This system is working for someone, and it's not us. So, that is a major barrier to what we 're trying to do. In summary, the participants identified negative stereotypes and racism as the most significant challenges to their work as school site administrators. Four principals cited having their professional expertise questioned as major barriers to their success. Systemic inequities and the devaluing of Black students were cited by four principals as significant challenges to their positions as African American female elementary school principals. As highlighted by the stories of the women in this study, the intersection of race and property have a profound influence of the education system from policies to individual perceptions. The stories of these women are an example of how race continues to be a significant factor in determining inequity in the U.S. The lack of resources, the negative perception of others, and the lack of respect for the educational experiences of Black students as gleaned from these stories suggest that racism in America is not a series of unrelated, isolated, and independent acts. Racism is instead engrained in the nation's institutions and structures as posited by critical race theorists. African American women school leaders and other communities of color lack the 
property rights associated with Whiteness. With Whiteness comes intelligence, access to resources and the right to use and enjoy those resources. The stories of these African American women principals communicate the experience and realities of an oppressed group as not having access to these same privileges and, are instead, the object of others' domination.

\section{Defining Their Roles as Urban School Leaders}

With nationwide calls for increased accountability and student learning, principals no longer have the responsibility of being merely site managers - maintaining the school's day-to-day operation. Principals are now required to seamlessly maintain high expectations for student learning, monitor and support teacher practice, evaluate programs and cater to the needs of parents, community leaders and district officials while ensuring safe and well-maintained facilities and balancing budgets. During the next phase of our discussions, principals were asked to define their roles as African American elementary school principals as well as describe experiences that they view as illustrations of their role as principals in urban school districts. Both their experiences and the roles that they perform in their positions as school site administrators are heavily influenced by their race and gender. According to veteran principal Kelly, who has been an administrator for nearly 5 years, "The principalship has changed. I remember when I first got the position I could focus on students and teachers. Now I feel like I'm responsible for an entire community of people." Much of the conversation 
centered around four roles that the women in this study highlighted as essential functions of their positions-role model and ambassador, community partner and resource, advocate for Black children, and savior.

\section{Role Model}

All six administrators stated that being a role model for their students and community was an important component of their responsibilities as school leaders. "I want my students to see me as reflections of themselves," says Amel in describing her interactions with students. "I want them to look in my face every day and say, 'This can be me." Research on African American culture documents the importance of reciprocity in the Black community (Fairclough, 2007; Williams, 2007). For these women, attaining their positions as principals allowed them to reciprocate the support and encouragement given to them by being role models to their students and community. Christine's comments highlight this cyclical relationship and are an example of how, for the women in this study, their roles as principals are not distinctive from their roles as members of the Black community:

There are children at the school who look like me. So I think my role is to show the children that you can do this, too. Here is a teacher or a principal who looks like me and yes, I can do this, too. And to the larger community, that I have somebody in the community that has elevated and is in the position to really push our community forward. I think even more for my role is defined by that 
because I grew up Oceanside and now I'm the principal. And my role is not just to educate the students, but to be a hope. People can see that even with life's adversity, you can still rise above, and still come back and represent your community.

Kelly described her childhood and growing up with role models that helped motivate her to further her education and give back to her community. She recalls, "There were people I looked up to as a child. People who help inspired me to do good things with my life." Kelly uses her position as school principal to combat the negative images of African Americans perpetuated by a racist society. Being a role model allows her and the other women in this study to resist stereotypical views and oppressive actions by offering an alternative voice and image that empowers their students and community. She stated:

First and foremost, I am a model for my students. That is an alternative to what they normally see for Black women, and African Americans in general in the community. Unfortunately, they live in a blighted area, and sex and violence are glorified. For a boy in this neighborhood, I could easily see how they would think their only options are to become gang members, drug dealers, or rappers. And, for girls, what are their options? Teenage mother, video vixen, hair braider, or a drug dealer's girlfriend. I am here as an example of what you can become as an African American and as a Black woman. But, unfortunately, 
there are so few of us and the need for our students and our families to see more of us is so great.

Also commenting on the role models available to Black students at her school and using her position to inspire those in her community, Marsha offered:

Our children need to know that they can be something other than a secretary or a custodian. It's my job to show them that. It's my responsibility to let them know that they can have jobs where that requires them to wear a suit and tie or a nice pencil shirt, a blouse and blazer. I want them to know that Black people can have a nice corner office, too. I want to show them that a Black person can be in charge of things, and be professional. So, yes, I am a role model. That's my job and I'm happy to be that for my students.

Lauryn and Michelle both discussed being role models for some in their school communities and ambassadors of the Black race and African American culture for others. Lauryn, whose school population was predominately white until recently, discussed her role:

I am a beacon of light because the school that I am presently in has not ever had an African American principal and probably never had a principal my age - and I'm 20 years old (joke) - but, I think I'm a little bit younger than some of the other people that they had before and I'm probably the least traditional. Well, my school had been a relatively high performing school. The demographics have 
been one particular ethnicity and the teachers have all matched that ethnicity

for a number of years, however, in the last, I would say three to four years, the demographics have changed substantially.

Role Model and Ambassador

Leading a school with a student population of less than 5\% African American, Michelle finds herself continually balancing between role model for students and families that reflect her racial background and being a positive representative of the African American community for others who often harbor negative perceptions of Black people and culture. Despite the attainment of their positions, these women continue to face challenges in the workplace that are race- and cultural-based. Their experiences being competent leaders and being stereotyped and marginalized reveal that they are in a continual process of overcoming daily struggles because of their racial and cultural identification. Michelle's story highlights this dual role principal and ambassador of the Black community:

When we were first becoming the feeder, the identified school for Russian speaking families and Vietnamese speaking families, representatives that were Russian speaking and Vietnamese speaking would show us that in the newspapers that it's written, when you come to the United States, beware of the blacks. We always wonder why, yes there are immigrants from everywhere but it seems a lot of the time when the immigrants come here, that they're very 
disrespectful to us as people and so I was like, what is that about. But, it's like they've already been forewarned about a group that should be looked out for, be careful of your involvement, be careful of you know, if they're in your surroundings. So, I felt that ok, that alone to me had to show that ok, you have to see that there are people of all cultures that are doing a fantastic job and there are people of all cultures that are breaking the law and it's like the whole group is not breaking the law. Some of us are striving for something better for themselves and for their families. I think when I was starting to get the changeover of the more affluent families, they did not see a person that identifies with making sure that students from all cultures are showing growth and success, and being honored and acknowledged and accepted as part of their school family. All of a sudden they felt that they needed someone who looked more like them to represent them as having the leader of the school. So, along with that I'm the only African American principal that is not working in an area working with predominately African American students. It's hard to gain respect from people of other cultures.

Functioning as role models for their students and community was an important role identified by all six principals in the study. These principals perceived their duty as Black female school leaders to ensure that their parents, students and other members of their communities have positive images of African Americans women and are inspired 
to achieve and excel. This act of reciprocity has traditionally been a significant component of the Black community and continues to play a role in how these African American women perform their duties as school leaders. Undoubtedly, their stories indicate that race is central to their execution of their positions whether their living examples of educational and professional success or working to dispel negative impressions of others who subscribe to the dominate view of Blacks in America. For the women in this study, their roles as pillars of their communities and ambassadors of their culture were key functions of their duties as elementary school leaders.

\section{Instructional Leader}

Although the various roles of the principalship permeated interview discussions, one role that was of particular significance to all participants was that of instructional leader. Instructional leadership is an essential factor in facilitating, improving and supporting the academic achievement of students. Research in the area of school improvement and effective instructional leadership has yielded many behaviors exhibited by successful school leaders including having high expectations for students and teachers, an emphasis on instruction, focused and ongoing professional development, and the use of data to evaluate students' progress and monitor and adjust programs. Although this list of characteristics may seem short and uncomplicated, carrying out these tasks is a tremendous undertaking when compounded by race and gender. For the women in this study, providing effective instruction to the students they 
serve is critical in countering hegemonic structures. Being an instructional leader puts them at the forefront of social change and improving the Black community through the education of its children. Amel, who relies heavily on her success as a classroom teacher, was "excited about using my skills to improve teaching and learning. The only way we are going to move our people out of poverty and social strife is through education." Like Amel, the principals in this study all identified being an instructional leader as key to their positions as school leaders and their roles as members of the Black community.

Instructional leadership was a vehicle to address the issue of low student achievement for Black and other underrepresented minority students at their school sites. Ensuring success in the classroom for these principals meant ensuring their success by building their capacity as instructional leaders. Kelly described her need to be an effective instructional leader and remain current in her practice. She stated:

I have to stay on top of all of the relevant research and teaching practices as far as what works best for our children. I can't expect teachers to make these vast instructional changes to support our student population if I don't know what I'm talking about.

Similarly, Marsha described the importance of increasing her capacity as an instructional leader stating: 
I can't do my job as principal if I don't know curriculum and instruction. I feel like I have to attend trainings and get into classrooms, as an observer and a participant, if I'm going to be an effective leader. Knowing instructional practices and content is how I reach my students at the classroom learning level. Michelle also expressed her need to make sure students have access to quality instruction. Her comments reveal how she sees her role as a support for students through her support of teachers. Her need to stay informed of teaching and learning is an essential function of her role as a leader:

I have to make sure that students are getting what they need, so that means making sure teachers have what they need. I visit classrooms every day so that I know what students are learning and what teachers need to learn in order to be more successful. I'm not only the principal. I have to know what students need to learn and what needs to be taught at every grade level in every subject. Lauryn also expressed the importance of being a competent instructional leader. In her description of interactions with teachers, she maintained:

First and foremost, we as educators are here to educate children. You have to, as a leader, know how to teach and manage a classroom. I just can't tell teachers to do something without me knowing that it works. You have to be able to answer questions when they get posed by teachers who are looking to you for answers. You especially have to know curriculum and instruction when you 
work in the schools we work in because all of the teachers, or the majority of them, are new. So, you have to stay fresh.

For these women, the need to maintain high levels of knowledge and proficiency is a result of their commitment to their cultural and school communities, as well as a mechanism for coping with the negative perceptions of White teachers and peers. In addition to being a knowledgeable instructional leader, Amel discussed having to combat negative perceptions when it came to her ability to offer credible instructional advice. In her description of how she supports classroom teachers, she declared: My job is to be an instructional leader but, then being very transparent and saying, 'here is what I'm looking for, here are the strategies that are research based. I've used them myself. I didn't just pull these out of the air. There was resistance from individuals in the beginning. I had to physically go into classroom saying, what do you want me to do to help you, well I'm not quite sure how TPS looks or checking for understanding or wait time. Want me to come up with a lesson and then me putting myself out there to say, I'll come do it and going into five different classrooms modeling the lesson and showing the strategies and leaving them in and out just like that. Also, modeling practices for classroom management. That was a piece that was very negative. Just push out, kick out, get out where the office was supposed to be this space and they still try at this point to make the office space to babysit the kids that they don't want in 
there and with me pushing it back, going problem here because they're not calling the parents.

Putting systems and structures in place that capitalize on the brilliance and eagerness of students is a difficult task for many school leaders. For the participants in this study, combatting low expectations and ensuring that teachers have the proper tools to provide effective instruction was an important role for these principals. My discussions with all six principals suggested a need for each of them to create experiences that positively impact teaching and learning, and eradicate the complacency that plagues so many urban public schools. As African American females, race and gender are at the heart of how they provide support to their school communities. Taking responsibility for the education of children was universal among all of the participants in the study and reflects traditional role African American females perform within the larger community. As Christine expressed, "It's my job to make sure that everyone learns and grows, including me." Ensuring that students are afforded the opportunity to benefit from rigorous instruction while combating racist practices and negative perceptions make the role of instructional leadership increasingly complex, but does not deter them from their mission of improving their communities.

\section{Community Partner and Resource}

Many of the services required by schools to help them in supporting students, families and teachers are not provided by districts or funded with school budgets. For 
the six principals in this study, garnering community resources was essential in providing the support necessary to positively impact the lives and learning of students and their families. Having their schools utilized as community resources was a goal of each of the participants and their seeking out organizations and partnerships that helped them in that mission was another role identified by principals in this study. Siddle Walker $(1996,2003)$ in her exploration of segregated African American schools in the South in the mid- $20^{\text {th }}$ century, found that the relationship between these schools and the Black community was one of mutual support and caring. According to Siddle Walker (2003), African American educators believed the scope of their work extended beyond the walls of the classroom and school into the larger community. Educators were not only concerned with providing students with a sound academic foundation, but they also fostered for students and their families "caring" learning environments that supported their social, emotional and cultural needs. This counter's the dominate belief that schools serving predominately African American student populations are inferior or otherwise deficient. Siddle Walker's research gives credence to the work of African American educators in contemporary society who place value on developing positive relationships with the wider community. For the principals in this study, "caring" is an essential component of the roles as leaders as they work improve the lives of students and their communities. 
Christine discussed her role as a "caring" leader and the importance of building community relationships:

So I think my role, first and foremost, is to educate children, but when I move beyond that then you really see that there's a relationship with the parents and the school. I mean true, if the community needs something, the community sees my role as the principal as I can help get that something. They can say, "This is what I need. This is what I'm struggling with. This is what would help me." And the community waits for it to happen because they see me as somebody that can make something happen. In the schools in this area, we have to seek out the support of [community-based organizations] to supplement what we can't provide as a school. If I'm expected to run the school, then let me do that. Why should I have to raise money for the basic needs of my children and focus on teaching and learning to raise test scores with limited resources? Where's the equity in that? We should have what we need, right? That's how it should be, but it's not. So, I do what my school community requires. So, I think the obvious role is to educate because that's what we're supposed to do. But when the larger community and families see you as a real partner, and that comes from how you demonstrate, how you care, how you treat people, and how you provide for them and then when it's time to take care of business, how you take care of your business, what's your track record? Then they'll come to you for larger things 
and in turn, you can go to them. It's that family thing, but on a much larger scale.

At Fannie Jackson Coppin Elementary school, Marsha discussed her reliance on the community to help fill in gaps left when district resources are inadequate. Marsha felt that it was her duty as a leader to build and maintain relationships with community organizations in an effort to provide the services that her students and families needed. She maintained:

When the district doesn't provide whatever it is our students need, then it up to us (principals) to provide that. Now, we can't do it all, but we can find people who can do what it is we need them to do. I think, especially for Black principals, we're usually working with our students who don't come with the same background knowledge that other students do, so, we have to make sure we provide them with that context. That means going outside of the school to find them what they need.

One of the resources Marsha found was an organization that paired retired educators serving as mentors and teachers' aides with classrooms. Coppin Elementary benefited from the expertise of former education professionals, decreased its adult-tostudent ratio, and increased student learning with the help of the community. 
Like Marsha, Amel harnessed community resources in an effort to better support students and families. In recalling her attempts to provide students with an after school program, Amel stated:

We are right in the middle of three housing projects. You know, our kids see a lot of violence. If they leave the school too early and there's still some daylight left, we can expect trouble. I didn't want my students seeing or being involved in anything that wasn't right. I said to the district, 'We need an after school program,' and I was told that there was no money. You know, it was me either accepting that or doing my own thing and find my own resources. So, you know, that's what I did. I call up [a community-based organization] and agreed to provide the supplies and materials that we already have, and they provided the personnel. My kids got an after school program and are off the streets.

Faith-based organizations have also played a significant role in supporting urban schools. In recent years, as the economy has declined along with school funding, principals of urban schools have called upon local churches to fill the void left by years of financial neglect and scarce resources. Michelle stated, "I meet with the local churches quite often. They fill where we come up short in our school budget." Like Michelle, Kelly worked to foster relationships with the churches near Nannie Helen Burroughs School to support her school's learning programs: 
I remember going to church on Sundays and going to Sunday school. That was a big part of our lives. The women there would make sure our printing was just so and that we knew how to read those scriptures in the Bible. They cared, and I believe they (the church) still do. So, when we needed readers for our reading intervention program, and when we needed volunteers for our classrooms, I called the church. They were like an untapped resource.

Lauryn also used the church as a resource to support not only her students, but the larger community. She described some of the programs that have resulted from these partnerships:

We rely heavily on the Black churches in our area. One church mentors our Black boys and girls, and another has a food program that's open to all of our families. We just had one church wrap up their job training class that some of our parents attended, and I'm working with [the churches] now to form some kind of drug treatment program.

Although most of the principals in this study lead schools in economically depressed neighborhoods, they had an impressive ability to ascertain the needs of their school community, and recognize and leverage the resources available to them. For these principals, the concept of "caring" is one that drives how they interact with members of their school communities, and also how they provide support and encouragement. Addressing the emotional, social, academic and cultural needs of their 
students and families is illustrative of how and how much these women "care" for their communities. In doing so, these principals made efforts to ensure that students had what they needed to be successful learners, and parents and families had what was necessary to support students in their learning.

\section{Advocate for Black Children}

Another role three of the six participants in the study viewed as important aspects of their jobs as school site leaders is advocate for and defender of children particularly Black students. According to Lomotey (1993), critical to the successful schooling of African American students is the leadership of the principal. His research suggests that school leaders need to be committed to the education of African American students and have concern for their communities to order to positively affect their learning. For the women in this study, their racial identification and experiences as members of an oppressed group, shaped how they advocated for and supported Black students. Kelly communicated her frustration with what she views as a lack of support for Black students in her district and the education system as a whole. She commented, "With all of the educated people in this field, we know exactly what to do for our children. All of our students need to be a priority, not just the rich and White ones. Everyone needs to care." Amel spoke of her strong commitment to families and acknowledged how systems and structures are often not set up to benefit students in low socio-economic areas, and how a lack of committed adults contributes to the problem. 
She described one situation in which an African American student was transferred to her school from a school in a middle-class neighborhood and how she felt that he was not advocated for by the adults charged with serving him. Amel stated:

Inherently, I hope that people are coming to the table wanting to do what they would do at my campus that's in the middle of three projects exactly what they would do for my sister school that's up in the hills in the affluent community where there are million dollar homes. But in reality that's not what is always happening. I mean, most recently I had a student who wasn't working out, an African American student up in the hills, and he got [transferred] to my school. The parent comes in defeated as a single mom, actually the mom was going through a divorce and you could see the hurt on her face. She knows her child was pushed out and now [they're] down here, you know, with [their] people. Even though I don't necessarily feel like the practice was, 'let's look at what's best [for the student],' this student is yours. But, that's not what the parent felt when she came to me.

Amel went on to recall a situation in which a school psychologist tried to use a shortcut when assessing this student. Describing her perception of how students in lowincome areas are treated in contrast to students in more affluent areas, Amel recounted: There are individuals sitting at this table who simply don't care about our Black children. This person can put together a report with one student's name on it 
but, another student from across town, the facts about that student, write the report and not proofread it enough to see, 'Ooh, wait a minute. I can't send this out with two different school's names on it.' And nobody caught that. Then not thinking about it because this parent is poor and they're living in the projects over here. They're not going to be literate enough or intelligent enough to catch this. They're just going to take the paper work and put it away. Just to see the look on that parent's face. She was like basically, you didn't care enough to check and see that this isn't even my child that you're talking about. And then the parent questioning the validity then of this assessment - Do I really know if they assessed my child? Did they throw something together to shut me up and then to have this person who did the assessment (the school psychologist) tell the parent, 'Well, actually, I have 60 days to assess your child. I don't have to do it right away. 'Would you say that to the parents on the hill? You would use your best manners, curtsy and bow and everything else that has been taught to you. You wouldn't even make that statement. So, it's that piece of again, what are we bringing to the table when we're working in the urban space in the middle of three projects versus if we're in the million dollar community? This site, it's been ignored. I don't really feel like people have dug deep to hold everybody accountable. So, that's my job. This is our family, this is our community and we all need to do our part when we're sitting at this table. 
Michelle also sees her role as principal as a supporter of the interests of Black children. Serving in a school where there are significantly small numbers of African American children, Michelle found the task of constantly shielding her African American students from the inherent racism of district structures and the surrounding community arduous and taxing. She described a situation in which she had to advocate for an African American student who did not, according to some parents at the school, "fit in with the school's culture." She recalled:

Well, last year I started getting a few more African American students that were coming from, moving from other areas of the city to over on this side and I think one of the students wasn't quite up to par with some of his skills, wasn't that far behind but then when it came to taking care of his needs he kind of came in like gangbusters like, he would go out to the yard and was like ok, I'm here, he'd knock kids down as he's on his way letting you know, ok, you're not going to mess with me so we had to talk with him about, I appreciate that you know how to take care of yourself, but we're going to learn how to take care of ourselves a little bit differently. If something happens, we're going to talk to kids using words that are more appropriate. There's school language and I said, even when you become an adult, there's language that you don't have to use when you're older but you do need to speak up for yourself and so we had to work with that but I think probably the most hurtful part of that was when parents 
wanted to meet with me because they felt that he didn't fit in this school and that he should go to back to Oceanside. And so I had to have, I said, you know I have to have, they wanted to meet with me not about their child but about this child and I said I don't have meetings about other people's children because when the two mothers were standing there and I said right now you want to talk to me about this child but next time you two are friends right now but you'll want to have a meeting about your friend's daughter so I said so the meeting that I'm having to support what other children I work with those children's parents and then they said, ok, well then we want to have a meeting with you with why he's taking up so much time that the teacher doesn't have enough time to give my child what they need. I said, well I'll have to have a meeting with the teacher about that because the teacher has not expressed to me that she is having difficulty with the needs of the other students, so the teacher from then talked to those parents and they kind of backed off but then if I had been one that listened to them, now he still has some ways to go because people come from different experiences, his household experience is different where his mother is trying to make a change, braking away from how things usually worked in her family so she kind of moved away from where her family usually is but he's a totally different child now that he's in another grade and he's still here and I said everybody that comes to this school, no matter what they bring with them, are 
part of Cooper school family and that we need to work with them to make them feel accepted and so what was really hurtful was when they called mom in because we're like, ok maybe he needs to go through the student's success team process so that we can put an action plan in place so she kept missing the meeting or rescheduling or just not showing up and so finally when we cornered her, she came in and kind of in tears and really nervous and so we said we're just trying to see how we can work together as a team to make him be more successful at school and so she burst out into tears and said, I thought you were calling me to tell me that my child needed to go to a different school, and so I said, that's unfortunate, I said, I'm glad I don't have that type of power but even if I did, that's not the reason why I called you in to this meeting. He's a part of our school, he's a part of our family and so we need to make sure that you feel that you're part of this family and make sure he feels it.

Like Amel and Michelle, Christine expressed the importance of her role as advocate for the students she served. She discussed knowing how the needs of African American students are often overlooked and even neglected in schools outside of their communities. Her experience led her back to her neighborhood where she reports working to improve schools so that African American children could "learn at home:" We stay for the children. We're here, you're with us, and we know what you need. If I send you over to [a school in a more affluent area], then what's going 
to happen to you? You don't even know what you're fighting against. I worked two years at [a school in a more affluent area] as a kindergarten teacher, and I got out because I was like, 'Wooh, where is the love? Where is the caring for our babies? Show us that same love. That was different. So, as an administrator now, I speak up when I hear or see what happening at other sites that's not ok. And, you can't ignore me because I have my credentials, too.

The principals in this study extend themselves to foster growth in and development of the students they serve. They are keenly aware that not everyone subscribes to this sentiment when it comes to educating students who come from cultural backgrounds that are different from their own. Societal assessments of Black students are tainted with views of inferiority and deficiency. Despite these views, this study's participants challenge practices that perpetuate oppressive structures as a means of resisting the status quo. Advocating for the interests of African American children in the face of racial bias is yet another role identified by these principals as part of their positions as school leaders.

\section{School Savior}

School savior was a role half of the women in the study expressed as components of their positions as leaders of urban schools. Unlike the previously highlighted roles, this role is not one that is willingly accepted by Principals Lauryn, Kelly, Amel and Christine. Bloom and Erlandson (2003) suggest that administrative 
opportunities are often offered by district superintendents and school boards to African American women so that these leaders can "salvage their own people" (p. 346). Amel's comments illustrate what she believed is the perception of those who subscribe to the dominate view in education leadership. She stated, "After Black women, there is nothing else. If we can't turn things around for our children, then who can? That is a huge burden to bear, but we do it every day." This places the Black female school principal in a precarious position because when success as determined the dominate culture is not obtained, these leaders are often blamed and dismissed from their positions (Bloom \& Erlandson, 2003; Hill \& Ragland, 1995). Undoubtedly, racial and gender bias play a role in this phenomenon. These leaders are given a leadership title and position, but often lack the authority and resources to make substantial change. Already at a disadvantage in terms of the number of African American female school administrators, being labeled as failures only perpetuates the view that women of color lack leadership ability. Lauryn offered this view on the role of African American female principals and this overwhelming expectation:

I think in urban schools the push is that you're always discussing or working on school reform. As an African American female principal in an urban setting, the push is for you to come in and, operation wise, you are expected to come into a crisis situation and by virtue of your presence makes things better. In a nonurban setting, we don't discuss that as much. You really do a lot of observation. 
Where as in an urban setting, you roll up your sleeves and you jump in. You're like, ok, here is what we're going to do.

Kelly commented on the traditional perception of Black females in American society. Although African American women are known for their resiliency and resourcefulness, in the context of educational leadership, the expectation to produce results with minimal resources is a disadvantage. She lamented:

We are put in these schools to work miracles. They, meaning the district, figure we can make something out of nothing. That's their perspective. When all else fails, send in a Black person ... better yet, a Black woman. It's that slave mammy and single mother image of Black women that is so pervasive. It says, '[Black women] don't need much to make it. They can make things happen with little to nothing.' They put us in these challenging situations because they know we'll work ourselves literally to death for our children. They know we won't turn down an opportunity to serve our people. That's how [Black women] are used in this system.

Although the African American women in this study readily accepted their leadership positions, Christine spoke about the consequences of being an African American female school principal in a challenging urban school:

What happens when we don't make the grade? After the long hours, community partnerships, parent relationships, after being sometimes the only voice for our 
children, what happens when we can't do the impossible? We get axed. We get pulled from our sites, labeled as failures, placed with another Black woman, and the cycle continues. We 're like sacrificial lamb. When does it end? I don't know. Hill and Ragland (as cited in Bloom \& Erlandson, 2003) articulated the danger women of color face in their roles as education leaders:

Default situations are often offered to women. Many school boards, usually in inner city schools, face school leadership ... where a number of men have failed as leaders. With their backs to a wall, hiring a woman is the only remaining choice. This situation is especially common in the too rare instances when minority women are given administrative positions. (p. 346)

The role of school savior is one wrought with racial and gender-based subjugation. While African American women are given leadership positions, the extent to which they are supported in their efforts to educate students is questionable. Nevertheless, these women accept positions in the most challenging schools and work diligently to serve urban student populations. This commitment to students and their communities is often exploited as districts continue to place African American women in under-resourced schools with the expectation of significant improvement.

In summary, all six administrators stated that being a role model for their students and community was an important component of their responsibilities as school leaders in addition to being an instructional leader for teachers, and a partner for 
community and parents. Three principals reported being an advocate for Black students as a critical feature of their role as urban school leaders. In addition, half of the participants identified being viewed as a rescuer of their schools as a role placed on them by district officials. The role of the school site leader is vast and complex. The role of principal is further complicated for the women in this study when examined through the lens of race and gender. Despite their numerous and difficult functions as elementary school principals, these women managed to draw upon their cultural assets to help them in their work as leaders. Clearly, the common thread among all of these roles is the idea of communal support and collective concern. Much of their duty as school leaders involves interaction with, support of and support from the community. The narratives of these women tell a different story in terms of how one strives for and achieves success. For the women in this study, success for one is success for all which is in opposition to the master narrative that has, in essence, promoted a colorblind individualistic ideology. The voices of these women speak, not only to how race and gender complicates their roles as principals, but how important it is for them to foster shared, cooperative and communal spaces of teaching and learning.

\section{Redefining Success}

For schools in the public education system, success is often measured by test scores and state school rankings. Urban schools that serve predominately minority student populations are often plagued with external challenges that include poverty, 
racism, and violence, and internal barriers from low teacher expectations to the lack of appropriate resources. With high numbers of African American women placed in schools that face seemingly insurmountable odds, reaching traditional levels success may seem like a distant dream. My discussions with the participants in this study revealed that a contributing factor to their ability to sustain in their positions as urban elementary school leaders in the context of their race and gender, these women celebrated accomplishments not typically associated with school success. I posed the question, as an African American female school leader, how do you measure success, to determine what these principals valued and to give credence to their work with students, families, teachers, and community.

Like principals in other studies (Lomotey 1993; Tillman, 2004a), these six women placed students' academic success as their first priority. As Lauryn stated: Success for me means that I have fully trained teachers who are well versed in the standards, can execute and write rigorous instructions to all my students and all my students have access to my teachers and this is evident by improved test scores, low classroom management issues, and good parent relations.

However, the scope of what participants deemed as measures of success included increased parent participation, improved teacher practice, the fostering of positive community relationships, and their ability to support students and families socially and emotionally. Christine offered: 
Social success as well as academic success, I can't separate them. I can't say my kids are as smart all get up, but they don't know socially how to get along and interact. So I look at how kids problem solve, talk and get along with others. Yes, I want to see them achieve academically. You know, watching the progression of them academically, but seeing how they progress socially too getting along with others, talking, figuring stuff out because for some of my kids, they don't come with that. The [neighborhoods] that they come from and the things they have to do, being able to kind of separate home and school is hard. So, being successful is parents staying at the school and believing in it. Not saying that, 'I want to take my child out, I want to go to this other school because I think that I will be treated better. 'And, success means having the right teachers stay. Success for me would be not having a lot of turnover especially the people I really want to stay. Some turnover is fine, it's not for everybody. But success would be having teachers make a commitment to stay at this school.

Although Marsha leads a school that is considered high performing, she discussed how she chooses to measure success at her school and takes into consideration the economic and social obstacles her children face on a daily basis:

There are so many things as far as measure of success, when parents are happy, when children are happy, when teachers are happy, but one thing that often 
makes me feel so happy and makes me know that school is successful and a safe and happy place for children is when I see children skipping. To me, skipping means the best and lately I've been seeing parents skipping with their children out in the hallways so I'm like, we must be doing something very successful and just seeing how the whole school community has started to work together it makes me feel like we've been successful, plus our API has been going up so, and our achievement gap has been narrowing so that's a good thing too. When a school community works together for the good of all children, that's when you know you're headed in the right direction.

Like Christine and Marsha, Kelly also described multiple measures of success that involve building positive relationships with the community and her ability to meet the social needs of her students and families. This assessment is not viewed as a viable gauge of accomplishment according to dominate measures of success. The stories of these women will, however, help produce counter-hegemonic discourse that will serve to expand on the experiences of urban school leaders from the perspectives of marginalized groups. By adding to the discourse, these women are redefining what it means to be successful which has a profound effect on how African American women are viewed as leaders. Kelly stated:

For African American women in this role, success has to be looked at in multiple measures. It's easy for us to attach our self-worth to test scores. Our 
school is far from earning a blue ribbon or a distinguished school label. But, there are wonderful and exciting things happening at schools with brown and Black children. If it doesn't come from the state or the district, then it has to come from within and from the community because if we always rely on the news reports of test scores as validation of what we do then we'd go crazy. Success for me is having put into place systems and structures that support my students and families so that they can come to school ready to learn... things like food, clean clothes, medical and dental care, mental health services, housing... things like that. Yes, test scores and achievement are important, but we're fighting an uphill battle, and if I waited for someone to pat me on the back for [test scores] or validate me for [test scores], then I'd be depressed and under a rock somewhere. We have made major improvements at this school. Parents are involved, children like coming to school and teachers are staying for more than one year. That's success to me.

Christine's assessment of her success led her to the conclusion that the real measure of success, for her, lies in people as opposed to numbers and percentages. Her successes in terms of how she "cares" for her community is ultimately what keeps her coming back to work each day:

The scores may never tell how you enable kids to come to school clean. How you made sure that they had breakfast. You need all those things to make learning 
happen. The scores don't measure that. It just says how academically sound they are, if that. But it's all those relationships, so a parent can say to you, "Can I bring my clothes to school and wash them?" Sure you can and nobody will ever have to know. That keeps Johnny coming to school every day. How do I measure that?

The pressure to increase student achievement scores is tremendous. Test scores are often the sole measure of success for schools and their leaders. For principals working in schools plagued by obstacles such as limited resources, high teacher turn over, poverty, neighborhood violence and student trauma, high test scores may be a goal that is never reached. Despite this, principals in this study recognized and celebrated the achievements that are taking place at their schools that impact student learning. Having trained teachers, building relationships with community, harnessing resources and providing for students' and families' basic needs were all areas that these women pinpointed as successes. As in previous responses, the focus on the community is essential for these leaders. Preparing students for learning in these schools requires an unconventional set of tools that involves connecting with and including others in the process of positively impacting students' learning. As such, the principals in this study have redefined what it means to be a school leader and what it means to be a successful school leader. Traditional measures of success render some triumphant and others not. 
To give value to themselves and the work of their school communities, these African American women found additional and more meaning ways of gauging their success.

\section{Supports and Facilitators to Success}

Each of the women in this study set up and utilized support structures to facilitate their actions as elementary school site leaders. In recent years, researchers have shifted emphasis from explaining the causes for the underrepresentation of women in educational administration to a need to provide them with better support systems (Gupton \& Slick, 1996; Johnson, 1991). Particularly for African American women, the implications for sustainability in their positions as urban school leaders are considerable. When asked to describe the factors that facilitate their roles as elementary school principals in urban districts, two major themes emerged: supportive social networks, and God and family. The women in this study developed professional relationships that were of critical importance in developing these leaders and contributing to their sustaining in their positions. Also, of great importance in facilitating African American female elementary school principals in their positions was their spirituality. For these principals, spirituality is an integral part of their identities as educational leaders and a heavily relied upon support mechanism.

Supportive Social Networks

All of the participants in the study cited supportive, professional relationships as key to their sustaining in their positions as elementary school leaders. Three of the 
women in the study described their relationships with individuals serving as mentors while all six principals viewed informal gatherings with other African American female school site administrators as essential in encouraging them in their positions. Literature on mentoring and sponsorship suggests that supportive relationships are important in the development of African American women in educational leadership and their career advancement (Allen, et al., 1995; Gupton \& Slick, 1996). By participating in supportive relationships, these women engage in communal processes of healing and empowerment. According to Allen et al. (1995), these relationships serve as barriers to isolation and as a source of motivation, and women who have the benefit working with a mentor "found the experience so valuable that they tended to become mentors for other women in order to pass along the positive experience" (p. 412). Lauryn shared her experience working with retired principals in designing school programs that contributed to the success of her students:

I rely heavily on successful principals who are retired, who have implemented programs and practices where their schools were highly successful. When I have questions or need some advice, I call these women who guide me and encourage me. You know, they've been there.

Kelly also relies on the support of a mentor who provides a model for effective leadership practice, provides constructive feedback and encourages her to be selfreliant. She stated: 
I meet with [name] at least once a month. She led a school similar in population to mine. She really helps me be a better leader. She shadows me sometimes and gives me feedback on how I interact with people and the decisions that I make. You know, little pointers here and there, to make me more effective... a more effective leader. One time she ran a workshop and really gleaned a lot from her facilitation skills and the way she engaged the staff. It's nice to have someone give you feedback that you know it's tainted with some kind of superiority thing. I think as Black women, we already have an inferiority complex, even if it's subconscious. So, you know, getting constructive feedback from someone who has your best interest at heart is something that is so wonderful. It forces me to have confidence in what I do and the decisions that I make. As Black women, we need to support each other and have the support of other Black women who have had similar experiences or who can understand and guide us through our circumstances.

In addition to benefiting from a mentoring relationship, Kelly expressed how she is open to being a support to other African American women in the role of principal. This reciprocity is indicative of the African American culture and the need to give back to the community for the benefit of the whole:

And so along with that I've tried to make sure that I'm open to anyone that needs support. I think that as soon as anybody new comes along, I'm always saying, 
"Call me for anything, you know, if you need help with anything, if you're not sure about this, just give me a call." And sometimes when I don't hear from them, I'll give them a call and say, "How are things going? Do you need help with something?" And usually when you make that call, it's like you happened to call at the right time, this has been the worst day. And so I think just being a support to others, letting them know that I may not know everything but, just from the years that I have been here, I'll know at least those things that are helpful to you in the beginning. Because even though we may talk in meetings, there's hardly any time that you are able to get off the track of what the agenda is and a lot of times we just need to talk with one another to find out how things are and, oh, that's how you did that! Ok, I'm going to try that. So making the time to do that, to help another principal, especially a Black principal because I know how hard it is, I think is really valuable.

All of the women in the study discussed supportive social networks of other African American female elementary school administrators as an important component of their support structure. Principals reported that these networks, although informal, promoted solidarity and camaraderie among the group and diminished feelings of isolation or alienated brought up by the position. Christine described her experience meeting with other African American female principals for the first time and feeling comfortable in her space as a Black female school leader: 
I think you know honestly, like the group that we have, working with other African American principals. Being able to say, 'Ok, I just have to let loose,' and knowing it's not just me. Even those meetings that we had last year. I know people really wanted to get to business. I remember the first couple of minutes it felt like the first time we could just be Black. You know, this is a day in the lffe. I remember how [a person] kept wanting give our input, and we kept saying that in order for us give our input, we have to release something because we carry this all day. You can't call downtown to tell them anything. You can't talk to your assistant superintendent and say this just happened to me. It felt like such a release to tell people your story about the craziness that just happened to you today. We've never had that opportunity. It was the first time someone said, "Ok, tell me about the life of a Black principal and your experiences on the job." It's nice to have that release with just us and not have to refrain from saying certain things or be too guarded. "Ok, let me figure out a way to say this so I'm not perceived as being weak, I can't do it, it's too challenging. So, I have to say it a certain way and it takes more energy to think about it because I'm not just being totally real, this is what I really believe, right? But I would be reprimanded for asking for what you really need.

She went on to describe her participation in a district-sponsored professional learning community of African American female elementary school principals: 
I think when I got the chance to meet when we had the PLC (professional learning community). That felt like, OK it's not just me, you know, I have other people who experience this, too. It felt liberating, like I'm not alone. I can still continue with the struggle. I'm doing this. I'm doing that. Ok, let me get back on my bandwagon. When I hear different things that everyone is doing and I say, "OK, I'm going to go a little bit further." We need the experiences so we can be sure - we need the camaraderie, we need the support, and we need the good ideas so we can say, "What else can I do?, What can I do differently to make it happen? But to be honest, we, as Black women, don't want people to know what's really happening, so we sugar coat it and we don't say, "I'm drowning, I don't have my paperwork done, I need some help. "I think sometimes we take on the superwoman image and we don't want to be real with ourselves. In this group, we were able to keep it real.

Like Lauryn, Kelly and Christine, the Marsha recognized the significance of establishing supportive relationships with other African American female leaders. Marsha believes that mentors help legitimize her work and validate her as a leader. She reported her social network as the only time she collaborates with Black leaders in her district:

I think that one thing that I need is the support of my colleagues. I mean, as African American principals, us getting together, you know, once a month to me 
is really powerful and a blessing. And being able to reflect on the things that have happened during the month is very, you know, supportive to me. Outside of the group, there are certain ones that I talk to every week. I mean, we try to get together once a month, which I think is really good and we just really need to continue to do that. It's informal and we just talk about our situations at our school and if I have an idea, I could share and if that person has an idea, she could share. Basically that's when we talk. It's when I'm on my way home, going across the bridge, talking on the phone. Then when we all get together and have our conversations. Unfortunately, in our professional development groups, our principal groups, we are all in different groups so we don't get to see one another which I find to be absurd but, you know. So, we don't get to see each other at that time and you know, have conversations and talk and a lot of these principals have been principals longer than I have so I really respect them and you know, take their advice to heart and really try to do whatever they tell me that I should do.

Because the experiences of African American women leaders are often within the context of their race and gender, the value of expressing one's feelings, concerns or and successes without judgment is valuable both on a professional and psychosocial level. Marsha spoke on the value of meeting in affinity groups: 
I think it's very valuable because I think we all go through the same stresses. I think we all go through, I don't know, I think we all have the same problems and the same challenges and the same situations. I just think it's extremely valuable that we meet either to vent or to try to come up with a solution for whatever it may be.

Michelle expressed a need for African American principals to formalize these affinity group meetings into a more structured gathering, as do other ethnic groups, where principals can support each other in completing their daily responsibilities as school site leaders. She revealed:

I think it definitely helps to have relationships with other principals and I think sometimes you feel like you're the only one. I think to have the trust in your colleagues and have those kind of relationships, I think our meetings have been helpful. I think along with that then, we should be able to support each other to work on whatever those next deadlines are together and find that, ok, with both of your ideas sharing, you're able to accomplish the task quicker and I think it would help to solidify our group and help us grow as leaders. Not that groups should always be segregated, but my Asian principal friends have said they meet as colleagues in their Asian groups. The Hispanic principals meet because there's something about same cultures that support that you and your specific needs, not that they're leaving other people out but we know that there are 
certain things that are unique to cultures. So, I think it's been a benefit that we've attempted, finally, to do that ourselves this year to be of support. You know, it's not you just going out and eating dinner together, but you need to be there in case the other person needs something. It's always worked out where we don't have needs at the same time but your experiences that you share, things that you've gone through helps somebody else and vice versa. Although Kelly and the principals in her district do not meet in formal or informally structured social networking groups, she spoke of getting support from other African American principals in her district. She reported: I rely heavily on my colleagues, my sistahs. We all have the same issues and the same perspective on things, it's just nice to be able to bounce ideas off of them and just vent about our common experiences. I call them on the phone quite often, mostly on my way home or if I'm in my office late. This job is so isolating. We need each other, you know. When we do get a chance to meet at a restaurant or whatever, I like how we can talk about religion. We can talk about spirituality. It's really important for me to talk to people who have that same spiritual connection and not everybody believes in God, but most people have some sort of spiritual being that they believe in, and when we do get together, we aren't ashamed to pray. We can't do that in a district meeting, but I 
guarantee you, if it were just us and we started talking about testing, we would all turn into prayer warriors. That's the power of a sistahhood.

Lauryn also spoke of her informal social network as having a positive impact on her ability function in her role as an urban school leader. She maintained:

I stay on the phone trying to get home. Right, everybody is on the phone and nobody's listening because we're all telling the same story. I probably say I have two or three super good friends that are principals and we probably talk daily about you know, what someone said that was crazy, or how this teacher questioned our instructional knowledge. We talk about some of the things that we are challenged by all the time and there are principal meetings once a month but, it's mostly an opportunity for us to get information. There's not a lot of time for us to talk so we just kind of have to create our own situations for communicating with each other.

Like Lauryn, Amel finds meeting in affinity groups helpful in her practice as a school leader, but recognizes the need to expand these interactions. Here she describes a similar group in which she was involved. She stated:

I talk to other principals sometimes. The only way that that happens is that we seek out each other as an affinity group. We have our management meetings but, it's just, you know, once a month, but it's just a casual thing where we're checking in. We're talking but, there is no, you know, talking about stuff you 
really want to talk about. It's all work related, of course, but it's the way it's discussed at district meetings and who we're talking to. We aren't free to really get down to what we need to talk about. You know, I can't ask sistah to sistah questions. Oh yeah, I would love to do that. I mean, because that was one highlight that I appreciated in my graduate program that we could check in as African Americans. Because there were things in our graduate program we agreed with and things we didn't agree with, at least we could bounce it off of each other and share our different perspectives on it and it was a piece that got us through the program. Similar to that, there are things as principals, in our meetings and in our daily lives at our sites, that we experience as African Americans that we need to express or vent or get advice on. Supportive professional networks both mentoring and affinity groups play important roles in the success of the African American women in this study. These relationships provided principals with the encouragement and moral support necessary to sustain them in their positions as school site leaders. Research indicates that having a mentor leads to greater job satisfaction and sustainability (Allen, et al., 1995). Women, in particular, report increased self-confidence, improved opportunities for creativity and skill development. For African American women, it is critical that this avenue is explored and exploited as a means of support considering the challenges these women face in the workplace. 
Spirituality and Prayer

Spiritual practices appeared to be a fundamental component of how all six principals sustain in their daily lives as educational leaders. For all of the principals, their faith and belief in God was a significant support allowing them to face challenges and obstacles presented to them in their roles as Black women leading urban schools. Traditionally, the Black church and the belief in a higher power have been a structure of support for both African American men and women. As the women in this study revealed, spiritual support is central to their lived experiences as school leaders. The importance of spirituality in their professional work is expressed in the following stories.

Christine acknowledged the spiritual foundation that keeps her strong and allows her to continually confront the challenges of her job:

Praying is a support. I don't know how many times I've had to close my door for a prayer session. When things get too rough and I'm overwhelmed, I can't let people see me not in control of things, so I go into my office and give it to the Lord. When things get too hectic and it feels like things aren't working in my favor, I just close my eyes and say to myself. 'No weapon formed against me shall prosper.' That's my mantra. 
Despite work commitments and responsibilities, these women find the time to gain strength from their spiritual practices. Like Christine, Lauryn, too, relies on her faith for support.

And I have tremendous, unlimited faith. So, I go to church on Wednesdays and Sundays and I just give it up there. I bring all this stuff for Jesus.

Marsha also pointed to her faith in God as a critical component of her ability to perform in her role as school site leader. She asserted:

Just having a good sense of my spirituality and I don't go to church every Sunday but, I do go to church a lot and just when I go to church, just you know, giving things to God and not trying to take it back, especially when things get too difficult. Just give it to God and leave it there and he'll figure it out for you. Amen.

Kelly explained how her faith allows her to sustain in her role as school principal. She stated:

I don't know what I'd do without God. This job can be so hard. It can take a toll on your relationships, your health and your happiness. At some point, you just have to release it to the Lord. You know, I don't know how else to say it. Sometimes the only thing that can help me is deep prayer. No matter where I am, when I feel that anxiety bubbling up inside me, I take a moment and pray. I even have sermons on podcast on my iPod handy for when I need my spirit 
uplifted. Now, I've started listening to it as a prevention measure. God is so good. It's hard remembering that he has equipped me with everything I need. So, yes. I pray and pray often. I couldn't do this job without God. Amel also credited her relationship with God and her spiritual foundation for her ability to sustain in her leadership position. She provided a glimpse into how important prayer and spirituality are to African American women and how their spiritual beliefs provide extended opportunities for support:

I go to church twice a week. I've tried different ones. I was in between church homes, but I think I've finally found one that fits my spiritual needs. This job can take a lot out of you, you know. I mean, it's like a hammer and chisel, just chipping away, little by little. You don't feel it at first, but all of a sudden-bam. I think, as Black women doing this job, we need to pray. When I talk to my colleagues who are Black, sometimes, that's all we do. I'll call someone on the phone in the middle of the day or they'll call me, and all we say is, "Girl, pray for me."

Michelle recalled what led her to rely on faith to support her in her role as principal and how she has maintained the practice of prayer. She recounted: I really didn't pray much or go to church before I took this job. I remember it was my second year and I was dealing with so much negativity from the community because I didn't look like them, because I was Black. That year was 
so difficult that the only thing that saved me from going insane was God. I remember just getting an urge or desire to pray. It wasn't something that I normally did, I mean, I grew up in the church, but as an adult that kind of faded. But, that day when I got on my knees in my office and prayed, I've never stopped.

The centrality of God, spirituality and prayer in the lives of these women informs how they maintain in their roles as school leaders. Clearly, these women view their spiritual practices as an essential component of their work as leaders. In her study of twenty five African American women in leadership positions, Murtadha-Watts (1999) found that women often "refer to spirituality as their source of strength and guidance" (p. 156). Like these women, the principals in this study rely heavily on a higher power as mechanism to increase their resiliency as they work to educate urban school children.

Family Ties

Support from family was also essential in how these principals maintained in their roles as leaders. Three of the principals reported that they relied heavily on family for support as they performed their day to day leadership functions. For African Americans in the United States, family has always been a structure of encouragement and strength. The importance of family and community in relation to their work was clearly conveyed by Christine, Lauryn and Marsha. 
In addition to prayer, Christine reported that her family was a pillar of strength when facing the challenges of school site leadership. She stated, "My husband is like my sounding board. After I pray at work, I go home and unload on my husband." Like Christine, Lauryn views her family as a significant contributor to her ability to maintain in her position. She described seeking comfort from her family whenever she felt overwhelmed or discouraged. She commented:

I have a delightful family. My husband has angel wings and I know he was sent from heaven to me specifically. Some days it's extremely overwhelming but, I have to say that the backbone to my success has been my husband, my immediate family, and God.

Marsha also spoke about the importance of her family in supporting her in her role as school principal:

Family has also been supportive, you know. I think that if I didn't have the support of my husband and my children, it would be very difficult to do this job and I really do have the support from them. They don't want me to talk about school when I get home. I try not to talk about school. I just take my mind off of things by just doing things like looking at television and having conversations with my husband. I mean, that really helps me because once I start thinking about school, I just get stressed. My stress level goes up and in the age of iPads and computers and emails and Facebook and all that stuff, it's like you're 
forever working. My family is my backbone. They understand me and support me when it seems like no one else does. When all else fails, I can rely on my family.

Being able to depend on the support and encouragement of family was described as significant by half the women in the study as they perform in their roles as school leaders. Studies have shown that the availability of family support for African American women principals is essential in their sustaining in their roles (Loder-Jackson, 2009). These participants acknowledged the importance of family as a coping mechanism in their lived experiences as school leaders. These strong family ties enabled these women to confront the obstacles that surfaced in their work educating students in urban school settings.

To summarize, all of the principals in this study created and utilized support systems to sustain them in their roles as elementary school site leaders. Because African American women are typically assigned the most challenging urban elementary schools, their ability to sustain in their positions has far-reaching implications. The influence and centrality of family and spirituality was strongly denoted as an essential facilitator of their ability to survive and thrive in their positions as school principals. These women revealed the impact that their families had on their academic achievements as well as their success in their professions. The women unanimously reported that their feelings of increased self-worth were a result of the support they received from family. 
Additionally, their reliance on their faith and strong spiritual orientation as a support structure was reported. Billingsley (1992) in his examination of the Black family, maintains that spirituality and family connection are major aspects of African American resiliency. Therefore, it is not surprising that the participants in this study also point to supportive professional relationships as being critical in their development as leaders and sustaining in their positions.

\section{Conclusion}

As African American women, the elementary school principals in this study described how their race and gender influenced their roles as school site leaders. Encouragement and support from colleagues and mentors were essential in providing these women with the platform on which to step into the realm of educational administration. Role model to and ambassador for the African American community, instructional leader, community partner, child advocate and savior were all roles identified all roles performed by participants in this study as in their positions as school site administrators. Placement in challenging, urban school environments, career advancement and the negative perceptions of others based on race and gender were key barriers to their success as school leaders. Despite the obstacles imposed on their leadership capability, the women in this study, sustain in their positions by redefining what it means to be a success leaders and by relying on support structures that include social networks, a strong spiritual foundation and family. 
Chapter Five: Discussion and Recommendations

\section{Overview}

This study was guided by three research questions aimed to explore and better understand the lived experiences and perspectives of six African American female elementary school principals leading urban schools. I began this study as a means of (a) documenting the unique experiences of African American female principals at the elementary level, (b) describing in detail the challenges they encounter in their role as school leaders, and (c) investigating the ways in which African American female elementary school principals sustain themselves in their positions and what supports they perceive are needed to effectively lead urban schools. Lastly, this study sought to provide an analysis of the lived experiences of African American females leading urban elementary schools to fill the gap in the current body of knowledge and broaden the discourse in educational leadership.

The central research question and sub-questions that guided this study were: (a) What are the experiences of African American female elementary school principals?, (b) What are the challenges faced by African American women in their roles as elementary school leaders?, and (c) What supports do African American female elementary school leaders utilize and require to sustain in their positions as urban school leaders charged with improving teaching and learning? 
The study's qualitative methodology in the context of critical race theory and Black feminist theory allowed for the retelling of stories in the participant's own voices. With the use of narrative inquiry and qualitative analysis this study illustrated the experiences and perspectives of groups and individuals, and assign meaning to their experiences. Connelly and Clandinin (1990) wrote, "The principal attraction of narrative as method is its capacity to render life experiences, both personal and social, in relevant and meaningful ways" (p.10). In the context of African American female school leadership, narratives give voice to a group that has been traditionally marginalized and essentially removed from educational leadership discourse.

Using counter-narratives, the study found that African American female elementary school principals perform unique roles in their positions as urban school leaders. These roles include role models for Black students and the African American community, ambassadors of the Black race and African American culture, advocates for Black students in a system designed to fail them, and saviors of underperforming schools. Findings also reveal that these leaders experience distinct challenges and structural barriers that are centered around their race and gender that include how they are negatively perceived by others, their placement in the most challenging schools, and their lack of career advancement. Despite these challenges and their varied roles as leaders, the findings further indicate that African American female elementary school 
principals draw upon spiritual connections, family support and social networks to facilitate their success and sustain them in their positions.

\section{Interpretation of Findings}

I had always viewed African American school site administrators as warriors and was introduced, as a result of this research study, to women who work above and beyond, despite tremendous challenges, for children. Through my discussions with the six women in this study, I have an expanded appreciation for the work that they do and have validated my own experiences as an African American female in a leadership position. This study only touches the surface in terms of the degree in which these women and other African American female elementary school principals can add to educational leadership discourse. However, the analysis of coded data, which developed into the categories presented in Chapter 4, allowed me to group related categories based on the central question: What are the personal and professional experiences of African American female elementary school principals? As a result, three themes emerged The Role of African American Female School Leaders, The Challenges Faced by African American Female School Leaders, The Supports Utilized by African American Female School Leaders - all of which speak to the experiences of these women as they remain focused on the goal of providing quality education to all students. 
The Role of African American Female School Leaders

In recent years, the American education system has been at the forefront of political and economic debate. School leadership has undergone significant shifts in function and requires and ever-changing skill set, however, the experiences of African American leaders, particularly, women, have not been largely explored. Research question number one asks, "What are the experiences of African American female elementary school principals?" Study participants described their experiences in terms of the varied roles they perform in their duty as elementary school administrators. The role of the elementary school principal has expanded to encompass an increasingly diverse student population. Not only do principals play a vital role in the daily operation of schools working to foster positive and productive places of work for teachers and stimulating learning environments for students, in a climate of heightened expectations, today's school leaders are expected to be "educational visionaries, instructional and curriculum leaders, assessment experts, disciplinarians, community builders, public relations experts, budget analysts, facility managers, special programs administrators, and expert overseers of legal, contractual, and policy mandates and initiatives" (Davis, Darling-Hammond, LaPointe, \& Meyerson, 2005). In addition to these responsibilities that are critical in operating effective schools, this study found that African American women who lead urban elementary schools take on roles that are defined by their race, gender and class. 
The principals in this study served as role models to their African American students individually and the Black community as a whole. These women understood that their positions as school administrators served as an example for what other African Americans in the community could aspire to. Research on African American women in educational leadership suggests that Black women often function as role models for students, community and aspiring leaders (Allen, et al., 1995; Alston, 2000; Tillman, 2004a). According to Henig, Hula, Orr, and Pedescleaux (1999), "By the second half of the twentieth century, black teachers and principals were important role models and respected leaders in their communities" (as cited in Tillman, 2004a, p. 174). Just as the principals in this study were encouraged to attend college and pursue leadership careers, they, in turn, share the collective responsibility of inspiring a community from students and parents to teachers and other members of the community. This practice of "giving back" is tradition in the African American community and one that is valued heavily by the women in this study.

In addition to being role models for other African Americans in their communities, participants in this study also had a keen understanding of how race and gender negatively impacted their work as school leaders. Principals experienced being ambassadors of the Black race and having to advocate for African American children in the face of racial inequity. The traditional view of the role of ambassador involves building relationships. Politically, an ambassador visits countries to foster relations and 
strengthen political bonds. In the economic realm, a company might employ an ambassador to promote it's values and ideas. For some of the women in this study, being the voice of African American students and building relationships between the African American community and those occupying power positions was critical to their work in educating students. Because traditionally African American women bear the responsibility for "holding family together," the need to counter the negative perceptions and expectations of others was critical to these women in their positions as school leaders and galvanizing their communities to work for all children including Black children. However, in the larger society, White privilege and those in control of power structures force certain groups to the margins. Michelle experienced this first hand in her interactions with members of the Russian community. She discovered, "It doesn't matter how educated you are. If you're Black, you are at the bottom of the bottom. There is no equal. There is no individuality. You are your color and Black is bottom." For those in power or on the privileged side of the power continuum, race serves as a ticket to access and favor. For the principals in this study, however, not only building relationships with dominate groups, but representing the talent and intelligence of their people, and standing up for Black children were significant roles in countering hegemonic pre-assessments of an entire group of people.

Instructional leadership was also a role that the participants in this study reported as being a major component of their experience as school leaders. Facilitating, 
improving and supporting the academic achievement of students were reported by all six participants as their primary focus in their jobs as leaders. Research in the area of school improvement and effective instructional leadership has yielded many behaviors exhibited by successful school leaders including having high expectations for students and teachers, an emphasis on instruction, focused and ongoing professional development, and the use of data to evaluate students' progress and monitor and adjust programs (Jackson \& Kelley, 2002; Knapp, Copland, Plecki, \& Portin, 2006; Knapp, Copland, \& Talbert, 2003; Leithwood, Seashore-Louis, Anderson, \& Wahlstrom, 2004; Waters \& Grubb, 2004; Waters, Marzano, \& McNulty, 2003). Although this list of characteristics may seem short and uncomplicated, carrying out these tasks is a tremendous undertaking that requires knowledge, skill and support. For the participants in this study, serving as instructional leaders was key to their ability to support teaching and learning. Central to the experiences of all six principals regarding instructional leadership was building their capacity as leaders and their knowledge of teaching practice, curriculum and subject content. Marsha described the importance of increasing her competence as an instructional leader stating, "I can't do my job as principal if I don't know curriculum and instruction. I feel like I have to attend trainings and get into classrooms, as an observer and a participant, if I'm going to be an effective leader." Literature on how working class and minority women use educational success to resist societal structures that work to subjugate and oppress them in comparison to males, 
speaks to the need of these African American women to continuously develop as instructional leaders (Cammarota, 2004; Fordham, 1996). Christine, who has received extensive training in culturally relevant pedagogy, comments, "Not knowing what I'm talking about or being able to practice what I preach is a sign of weakness, and as a Black woman in this position, I have to know more and do more than anyone else would or could."

Another role participants highlighted as a component of their positions as elementary school principals was community partner. Ensuring that their schools were sources of community development and growth was an important undertaking for all of the principals in this study. For many of these principals, school budgets often fall short of what is required to meet the needs of their students and their families. According to Rubenstein and Miller (2005), schools serve students with different levels of need and the resources these schools receive must be appropriate for the particular populations of students they serve. Although, garnering resources and providing services like after school programs, medical and dental assistance, mental health services and parent education classes presents one of the most troubling challenges for these principals, as Kelly described, the role of community partner as essential in not only providing resources for students and families, but in helping build relationships that are at the center of African American tradition. She as well as the other women in the study 
recalled experiences where they used her role as community partner to foster such positive community relationships.

Listening to the narratives of the women in this study, it was obvious to me that these African American female principals took pride in their duty as leaders of urban elementary schools. This sense of pride could be seen in how these women discussed their tireless efforts to improve the lives of their students and their families. The ways in which the principals described their challenges and their experiences in meeting those challenges was consistent with the limited amount of research on African American school principals (Jones \& Montenegro, 1985; Pollard, 1997). Literature on African American women in school leadership positions has generally emphasized barriers such as isolation and marginalization, and facilitators such as their commitment to the education of Black children (Pollard, 1997; Tillman, 2004a; Lomotey, 1993). An area that has not been largely researched, however, is the notion of African American female school leaders as the savior of urban public schools. According to Bloom and Erlandson (2003), African American women often take on the role of "messiah" in urban public schools and are frequently charged with "salvag[ing] their own people" (p. 346). This role of school savior was expressed by half of the women in the study as a component of their positions as leaders of urban schools. Discussing how she feels as a leader, Amel poignantly stated, "After Black women, there is nothing else. If we can't turn things around for our children, then who can? That is a huge burden to bear, but we do 
it every day." Although Amel and other principals work diligently to foster supportive and academically stimulating learning environments for their students, limited resources in urban schools and other challenges impact what can be realistically accomplished (Bloom \& Erlandson, 2003; Cistone \& Stevenson, 2000; Tillman, 2004a).

The various roles of the principalship found in this study- role model, child advocate, ambassador, instructional leader, community resource, and savior - illustrate the unique experiences of African American female elementary school administrators. Although these women carry out many responsibilities, all six principals took their roles as leaders very seriously and had high expectations for all members of their school communities. The principals were able to identify the functions of their positions and the experiences that most succinctly demonstrate their positions as urban school leaders. These African American female elementary school principals experienced leadership situations that stretched the scope of their leadership positions and ultimately improved and increased their capacity as urban school leaders.

The Challenges Faced by African American Female School Leaders

Non-traditional school leaders - those who are female and/or of color - face many challenges on the journey to school success and increased student achievement. For African American female school leaders, these challenges are compounded by their dual identity as Black and female. Research question number two asks, "What are the challenges faced by African American women in their roles as elementary school 
leaders? "As the study suggests, principals' perceptions of their obstacles and barriers center on three key areas - placement in challenging schools, lack of career advancement, the negative perceptions of others, and the lack of adequate resources. Research studies have documented the challenges faced by African American female school administrators. The literature, however, on African American female principals at the elementary school level is less robust. According to King (1995), African American women who hold leadership positions in education are often the victims of double jeopardy. Not only do they experience inequity and negative perceptions based on gender, they also experience oppression as a result of their race.

The women in this study acknowledged that their race and gender factored into their leadership assignments and access to higher leadership positions. Placement in the most challenging urban schools and the lack of career advancement were cited by four principals as major barriers to their roles as school leaders. The placement of African Americans in urban schools with high populations of low-income students of color has been well documented (Bloom \& Erlandson, 2003; McCray, et al., 2007; Tillman, 2004a). Research has continually shown that Black principals overwhelmingly head schools that have a predominately low-income and African American student population. As Christine noticed, "All but one of the Black women [principals] in this district are at schools in this (African American) neighborhood. "Although the literature on African American women school leaders, specifically, is sparse, the research that 
does exist points to racism and gender bias as the primary culprits for the practice of assigning Black women to head the most challenging schools with the least amount of resources (Tillman, 2004a). Research on the placement of African American women indicate that these women are offered the most difficult assignments in higher numbers than Black men, white men and white women, and are their primary entre into school leadership (McCray, et al., 2007).

For these African American women, what is at issue is not who they serve, but how they are held accountable for maximum results with minimal resources, and how who they serve limits their ability to advance forward in their careers. In addition to placement, the lack of career advancement was also cited by the principals in this study as a significant obstacle to their leadership positions. Like the placement of African American female school leaders, racism and gender bias must be acknowledged as contributing factors to the disproportionate number of Black women who obtain positions and remain at the elementary school level in urban districts. Literature on African American women and their placement suggests that the historical legacy of American society reinforces practices that benefit certain groups while oppressing others. Currently, African American women are offered positions almost exclusively at the elementary level while Black men and Whites are offered secondary positions. This is problematic because individuals advancing to higher paying and more influential positions such as superintendent and central office management typically have 
secondary school administrative experience. Collins (1990) Black women occupy marginal positions in academic settings. hooks (2000), "being oppressed means the absence of choice" (p. 5)

In addition to their placement and lack of opportunities for promotion, nearly all of the principals in this study experienced the result of negative racial and gender-based stereotypes. Five principals expressed that their race and gender often hindered their ability to effectively engage their school communities. These women described experiences where they felt their authority and expertise were questioned despite having acquired their positions with the proper training, education and credentials. Marsha summarized, "It's interesting how hard we work as Black women to get where we are, and then work hard in our positions, only to be looked down upon, not valued, and second-guessed." Collins (2002) posits that African American women face opposition in their capacities as leaders because they are seen as "the outsider within." In a profession dominated by White women, in general, and White men at the administrative level, African American women often find themselves working to remedy the effects that their race and gender on have on their functions as school leaders. The principals' concern for being perceived as incompetent by both professional peers and classroom teachers based on their racial and gender identity is also addressed by critical race theory. Their references to having to "prove" themselves is their acknowledgement of societal structures that exist to protect and maintain inequities in the education system. 
Critical race theory challenges these hegemonic structures that marginalize oppressed groups and focuses attention of the structure of white privilege and power. The notion of whiteness as property introduced by CRT scholar Cheryl Harris (1995) describes how White racial identity has value and shares the same rights of property including transferability rights, the right to use and enjoy, reputation rights and the right to exclude others (DeCuir \& Dixson, 2004; Harris, 1995). The African American women in this study were excluded from possessing status as competent and knowledgeable leaders. The right to automatically benefit from such status is denied them as they lack the privilege associated with the dominate culture, thus feeding their need to continually exert effort to resist negative labels and categorizations as inferior leaders.

As the principals shared their experiences as leaders whose goal it was to educate students at high levels, another challenge that surfaced in our discussions was the persistent shortage of resources and support provided their schools. Three of the principals pointed to the lack of adequate resources and support as a significant obstacle in their roles as leaders. As their narratives imply, these African American principals were not presented the same support and resources to be successful in their positions as were their White counterparts. Kelly movingly stated, "With all of the educated people in this field, we know exactly what to do for our children. All of our students need to be a priority, not just the rich and White ones. Everyone needs to care." Although the principals in this study worked diligently to provide safe, caring and supportive learning 
environments for students and staff, limited resources and insufficient support impacted what they could accomplish as school leaders. These women reported often feeling isolated in their positions, being left to fill in financial and personnel gaps, and singlehandedly resolving some of the most difficult problems and issues. If these African American principals did ask for assistance from their superiors, it may be interpreted as complaining and as an inability to meet the demands of the position. Christine expressed, "In the schools in this area, we have to seek out the support of [community based organizations] to supplement what we can't provide as a school. If I'm expected to run the school, then let me do that." She added, "Why should I have to raise money for the basic needs of my children and focus on teaching and learning to raise test scores with limited resources. Where's the equity in that?"

African American female school principals face leadership barriers and challenges on two fronts. First, traditional practices have afforded whites access to certain privileges not presented to other racial minority groups, and the privilege of being placed in positions that facilitate professional promotion can be considered such a privilege. This privilege afforded to whites is what CRT scholar Cheryl Harris (1995) identifies as Whiteness as property. Through practices that relegate Black women to elementary school positions in largely African American communities and restrict their access to promotion, school districts have served to reinforce this notion of Whiteness as property giving credence to a system that provides material and symbolic privileges 
and rewards possessed, used and enjoyed exclusively by Whites. Their placement at their school sites and the lack of opportunities for promotion, negative stereotypes and the shortage of resources and support confirm the existence of hegemonic structures that serve to limit their position while maintaining control for those in power. These six African American women principals acknowledged that racism exists and as African American women in leadership positions they experienced overt and surreptitious acts of racism in their school districts which were controlled by the institutionalized racist structure of White privilege.

The Supports Utilized by African American Female School Leaders

In an effort to meet the challenges of developing practices and systems that effectively support teaching and learning, the participants in this study have had to utilize support structures to sustain them in their positions as school site leaders. Research question number three asks, "What supports do African American female elementary school leaders utilize and require in order to improve teaching and learning in urban schools?" Participants in this study identified four key support structures that help them navigate in their roles as urban elementary school principals: Spirituality and prayer, family, mentors and affinity groups, and redefining success. The findings of this study and others suggest that family, community, and spirituality are essential components to the persistence of Black women in their roles as leaders (Bloom \& Erlandson, 2003; Murtadha \& Watts, 2005). 
Spiritual practices were a vital element of support for all six principals in the study. For these principals, their faith and spirituality served to guide them through difficult situations with the women unanimously reporting stealing moments of prayer during the day when the duties of their jobs seemed overwhelming. This reliance on a God and faith is consistent with literature on African American women and how they use their spiritual practices to help them confront challenges faced in their daily lives. For the women in this study, prayer and unrelenting faith was a significant source of empowerment and strength when dealing with the obstacles they often encounter in their roles as African American female school leaders. Jones and Shorter-Gooden (2003) assert that for Black women, "Seeking spiritual and emotional support can be a way of shifting away from feelings connected to bias and prejudice, exploring alternative problem-solving strategies, and garnering a new perspective.” The authors also contend that, "This spiritual shift enables many Black women to forge ahead valiantly no matter how trying life becomes (p. 81)."

Other studies have documented the importance of spirituality in the lives of African American women as school leaders (Bloom \& Erlandson, 2003; Creighton, 1999; Vaill, 1998). In a study of seven Black females in higher education administration, Webb (2000) found that spirituality offers reassurance, guidance and support to African American women in leadership positions as they face challenges and obstacles in their work environment. Christine, who described having private "prayer 
sessions" in her office, as well as the other participants in the study, confirm what the literature suggests about Black women and their use of spiritual practice as a support in their professional lives. Christine offered, "When things get too hectic and it feels like things aren't working in my favor, I just close my eyes and say to myself. 'No weapon formed against me shall prosper.' That's my mantra."

In addition to spirituality, all of the principals in the study were influenced by a strong, supportive family structure. Research on the experiences of African Americans and centrality of the Black family suggests that family plays a key role in the lives of African Americans and how they sustain themselves in the wider society. McAdoo (2007) suggests that the African American family has operated as a refuge that protects individuals from frequent acts of racism and has provided much needed support structures that are unavailable in institutions dominated by Whites. In the context of this study, all six women revealed the impact of their families on their professional day-today lives and how they navigate within their organizations. Like the solace they gain from their faith and spiritual practices, the women presented in this study gain strength and encouragement from their family bonds. They described their families as consistent pillars of strength that allowed them to maintain their emotional well-being in spite the demands of their jobs. This finding is consistent with other studies that focused on Black female school leaders (Loder-Jackson, 2009). As Marsha candidly offered, "My 
family is my backbone. They understand me and support me when it seems like no one else does. When all else fails, I can rely on my family.”

Another facilitator of the African American women in their roles as principals highlighted in this study was their use of social networks. Social networks, for these principals, manifested as structured mentoring relationships and organically-formed groups of other Black female elementary school principals. Mentoring relationships were utilized as a method of support for two of the women in this study. Both women reported regular meetings with retired African American principals as beneficial in increasing their capacity to be more effective school leaders. Research on the experiences of African American women in mentoring relationships suggests that these women benefit from the opportunity to discuss ideas, solicit advice and get feedback in a non-judgmental and encouraging space. Howard-Vital and Morgan's (1993) study of African American women and mentoring suggested that psychosocial benefits, such as increased self-esteem, inspiration, and self-assurance were apparent functions of mentoring relationships. Kelly, described meeting with her mentor monthly, expressed, "As Black women, we need to support each other and have the support of other Black women who have had similar experiences or who can understand and guide us through our circumstances." Furthermore, literature on Black women and mentoring also implies that systems of support are essential in helping African American women as they struggle with the dual challenge and existence of race and gender, especially when 
they attempt to navigate in White male dominated professional structures (Allen, et al., 1995).

In addition to mentoring relationships, the women in this study created social networks out of a need to connect to like individuals with similar experiences in terms of race and gender. Universally, the women reported gravitating to other African American female elementary school principals to share experiences, knowledge and best practices. Welch (1996) affirmed, "Individuals tend to identify with persons who are like themselves on salient identity group characteristics" (p. 10). When discussing the benefits of meeting with other African American female elementary school principals, Amel offered, "Having people that you can talk to and bounce ideas off of with no judgment is like a breath of fresh air in this job." She goes on to state, "As Black women, we are always so guarded, so it's nice to be surrounded by people who understand and respect you and what you bring to the table." The way in which the principals in this study described the importance of connecting with other African American female school leaders is confirmed in the literature. Helgesen (1990) and Gupton and Slick (1996), reported that for women, networking with other female school administrators builds their capacity as leaders because it provides them the space to express their thoughts and concerns to others with whom they identify, respect and trust. 
Redefining measures of success was also recognized by study participants as a structure of support in their efforts to sustain in their positions as school leaders. Student learning and performance on state-mandated assessments are the typical measures of success for public schools and their administrators. Because African American women are placed in high numbers in low-performing schools in struggling communities, determining success based solely on student test performance is often an exercise in self-defeat. Like many school leaders, the principals in this study pointed to increasing student learning as their primary objective. Lauryn stated, "First and foremost, we as educators are here to educate children." However, for these principals, the acknowledgement of other achievements serves to redefine what it means to be a successful urban school leader. Research suggests that in order to create the most accurate and reliable representation of a school, multiple measures of data collection must be utilized (Bernhardt, 1998). Building positive relationships with parents and teachers, and fostering the development of positive relationships between members of their school communities was identified by all of the principals as a gauge of the effectiveness of their leadership. In addition, principals offered parent and student satisfaction, teacher retention and parent involvement as measures of their success as leaders. As Michelle stated, "When a school community works together for the good of all children, that's when you know you're headed in the right direction." 
For African American women in leadership positions in urban public schools, redefining success is key to their sustaining in their roles. As a support structure, the ability of the principals in this study to redefine their success was consistent with the literature on Black women and self-identity. According to Collins (1990), the oppression of African American women as a marginalized group originates at a personal level. The awareness of one's value and self-worth encourages personal growth and confidence or diminishes the spirit. By redefining their success and acknowledging their accomplishments, these principals gave themselves the permission to recognize their work and value their contributions to their school communities and their districts as a whole. Kelly offered, "It's easy for us to attach our self-worth to test scores. Our school is far from earning a blue ribbon or a distinguished school label. But, there are wonderful and exciting things happening at schools with brown and Black children."

The voices expressed in this study provided insight into the lived experiences of African American female urban elementary school leaders. Few students have examined the perspectives and experiences of this group of leaders and this study addresses that gap. The findings place African American women at the center of their authentic experiences as urban school leaders at the elementary level. Their counterstories revealed their unique positions within the American education system and the challenges and supports associated with occupying that space as a marginalized, 
but resilient group. Their comments supported critical race theory's notion of whiteness as property and the permanence of racism as well as Black feminist theorists' call for African American women to write their own stories and raise their collective and individual voice against oppression. Collectively, the participants acknowledged the dominant structure through which they navigate to perform their roles as leaders. This structure not only determines the roles performed by these women, but the obstacles and challenges they face in their roles. In the face of these challenges, the findings also revealed that the African American women in this study created a counterspace of spirituality, relationships, and self-definition to facilitate their success and sustain them in their positions as elementary school leaders.

\section{Limitations}

This study was limited to female elementary school administrators who were serving in urban public schools in the San Francisco Bay Area during the 2010-2011 school year. Therefore, any generalizations made should be applied to the scope in which this study was conducted. Because the study was limited to two urban districts and six schools, this study may not necessarily represent other urban schools and districts within the state and across the nation. Additionally, the results are not meant to be generalized to the leadership functions and perspectives of African American women in non-urban schools or non-traditional schools. Another limitation of the study is the researcher's presence during the data gathering process. The effect of the observer in 
qualitative research in unavoidable. As Bogdan and Biklen (2007) state, "Researchers can never eliminate all of their own effects on subjects or obtain a perfect correspondence between what that wish to study... and what they actually study..." (p. 39). Thus, the mere presence of the researcher could have had an effect on participants' responses to interview questions or behaviors during observations.

\section{Pillars of Effective Support of African American Female Elementary Principals}

Our education system and society as a whole continues to struggle with issues of race and gender and the impact that racist and sexist practices have on the subjugation of women and people of color. African American women, with their dual identities, face tremendous challenges in as school leaders. Urban schools have changed drastically since the Civil Rights movement of the 1950s and 1960s when the call for educational equality was thrust into American society. Today, schools are more racially, linguistically and economically diverse, and the challenges urban school principals face are equally complex. Since the landmark Brown v. Board of Education ruling, schools in large urban districts continue to experience social and fiscal crises. Decreased financial support, shrinking student enrollment, violence and poverty plague urban centers and their schools (Loder, 2005).

In the face of these difficulties, an increasing number of African American women are leading the nation's most challenging urban schools. However, the voice of Black women is essentially absent from the research on the barriers leaders confront in 
the context of the contemporary urban environment. As a result, the constructions of knowledge within academe are limited to the master narrative and exclude the unique leadership experiences of African American female school leaders (Allen, et al., 1995; Bloom \& Erlandson, 2003; Tillman, 2004a). Developing literature on Black female principals indicates that their race and gender identifications differentiate their leadership locations and experiences from their White female and male counterparts (Bloom \& Erlandson, 2003; Case, 1997; Dillard, 1995; Pollard, 1997; Yeakey, Johnston, \& Adkison, 1986). This research positions the experiences of African American women principals at the center of the analysis rather than at the margins. The perspectives and experiences of African American female school leaders at all levels of the education system must be explored to give credence to the field as a whole.

The six African American female elementary school principals who participated in this study revealed that they encountered a multitude of challenges and heightened resistance in their school environments. Universally, they agreed that the bulk of the challenges they confronted were blanketed with race- and gender-related misconceptions and misunderstandings. These challenges not only limited their effectiveness as leaders, but also jeopardized their overall psychological and emotional well-being. The women in this study mediated these challenges by creating counterspaces through which to manage the distinct demands of their positions as elementary school leaders in urban settings. Findings from this study demonstrate a 
critical need to acknowledge, document and present the voices of African American female elementary school principals in education leadership literature, examine placement practices and improve support structures for this group of leaders. Recommendations for research and practice that emerged from the findings of this study will be presented in three pillars that propose a theory of effective support for African American female elementary school principals.

\section{Pillar Number One: It Takes a Village}

It takes a village to raise a child is a popular African proverb with an obvious message - the whole community has an essential role to play in the growth and development of its young people. In addition to the vital role that parents and family members play in a child's development, this ancient proverb suggests that the broader community too has a responsibility in how children are supported and encouraged. Taking collective responsibility and ensuring the success of its members is a long-held African American tradition. The dynamic processes of community and kinship developed as mechanisms of support and encouragement as Blacks in America confronted racism and inequality in their struggle for civil rights and liberties. Today, the notion of collective accountability, support and inspiration is still relevant in how African Americans interact with a society that seeks to diminish their worth in order to maintain the power of the dominate culture. For African American elementary school principals, community and kinship draws upon the traditions of the Black family 
bridging the gap between the isolation of their professional careers and the inclusiveness of compassionate relationships and supportive bonds.

The African American women in this study highlighted supportive relationships with other African Americans as key to their persistence in their school leadership positions. These school leaders understood that working in isolation to meet the academic and social needs of the children they serve was an endeavor destined to fail. Instead, these women worked to build trusting relationships with colleagues, garnered support from family members and gathered strength from their spiritual communities. In dealing with the daily challenges of their professional lives, drawing upon external supports such as family and spirituality was an instinctive process for the women in this study. This intuitive understanding of how supportive relationships influence their capacity to lead created a space that allowed these women to form professional cultural networks that served to empower and encourage them in their roles as African American female school leaders.

Recognizing intimate personal and professional connections amongst African Americans female elementary school principals as viable mechanisms of support, school district leaders should establish cultural networking groups that allow Black female school leaders in similar settings to share their experiences, challenges and best practices. Having this opportunity would provide a much needed resource as these women mediate the challenges of leading in cultural isolation within a White and male 
dominated system. African American women in school leadership positions, however, should not rely solely on public school institutions to provide them with such structures of support. Black female principals must seek out other Black female school leaders and create networks of support that align with their unique cultural and professional needs. Once this network of culturally-congruent education professionals is given priority, the obscurity that plagues African American females at the elementary school level will be confronted. According to Collins (2000), for African American women, developing support networks provides "significant resources for coping with the challenges of being Black and female - for managing the myths, negative stereotypes, and discrimination of the outside world (p. 259)."

\section{Pillar Number Two: Each One, Teach One; Each One, Reach One}

The phrase Each One, Teach One can be traced back to the early 1800 s when the United States was in the midst of slavery. For slaves and their teachers, the exercise of reading and writing was a dangerous and illegal one. Denying Blacks, both enslaved and free, an education and keeping them in a constant state of ignorance was a means of maintaining power and control used by White owners and law makers. In most southern states, anyone caught teaching a slave to read was fined or imprisoned. Slaves themselves often suffered severe physical punishment for the crime of literacy. Despite these atrocities, for many slaves, the ability to read and write meant freedom - not actual, physical freedom, but intellectual freedom. This intellectual freedom allowed 
African Americans to maintain relationships amongst family members separated by the slave trade and removed the veil of ignorance that maintained their oppressed condition. Consequently, the motivation of many slaves to be educated outweighed the hostility and aggression expressed by their white owners. Understanding the value of an education, African Americans who were taught to read and write were expected to reciprocate or give back to the community by teaching other African Americans to read coining the phrase Each One, Teach One (Williams, 2007).

This phrase continues to symbolize the sacrifice and commitment of the African American community to the empowerment of its members. Today, the phrase has been modified and adopted by many individuals and organizations dedicated to improving the lives of African Americans in this country. Each One, Teach One; Each One, Reach One reflects the commitment of those who seek to empower groups that have traditionally occupied the economic and political margins of society. For African American elementary school principals, learning from the expertise of others and benefiting from professional relationships is essential to their sustaining within and advancement beyond their positions.

For the six elementary school principals in this study, this notion of Each One, Teach One; Each One, Reach One and access to "freedom" is critical in their support of students and their achievement. A consistent pattern among all of the women in this study is that professional relationships matter. A key relationship that education 
literature continually cites as beneficial is that of the African American woman leader and mentor (Allen, et al., 1995; Crawford \& Smith, 2005; Patton, 1990). Mentors advise, coach, and encourage, and are valuable resources in terms of the support they provide to African American women in the field of education. Although only half of the participants in this study identified having a mentor as a significant means of support, all of the principals acknowledged at least one person that supported them in their positions as school leaders. Amel commented, "I have a mentor who guides me in my life as a principal even though we may not use that word to describe our relationship." Gupton and Slick (1996) define a mentor as "one with whom you have formed a professional, interpersonal relationship and who provides beneficial career and psychosocial support to you" (p. 92). Because African American women are placed in some of the most challenging schools, education institutions and professional organizations must take a closer look at how they provide support services to this group of leaders. Districts, universities and professional associations should create structures that facilitate the formation and maintenance of supportive relationships among African American female school site leaders and African American female mentors. Research on the experiences of African American women in educational leadership positions conclude that mentoring relationships are imperative because their influence and impact tend to weigh heavily on the leadership work of Black female school administrators (Allen, et al., 1995). Thus, efforts to recruit and retain African American female 
principals should include support systems that help them manage the duality of race and gender as they work to improve teaching and learning.

In addition to providing motivation, increasing self-confidence and facilitating professional growth, mentoring relationships have also been shown to have positive effects on career advancement. In their research study of thirty-eight African American female administrative certification and doctoral students working in or applying for administrative positions, Allen, Jacobson and Lomotey (1995) identify supportive relationships that go beyond typical mentoring relationships as sponsorships. The authors make a distinction between mentor and sponsor stating that a mentor is "someone who provides counsel and moral support" and define a sponsor as "a person who can actually open the doors of opportunity and employment" (p. 410-411). Having a sponsor to steer African American female principals down a path toward increased career opportunity and connect them to vital professional networks is a significant factor in improving the status and influence of Black women at the elementary level. Through mentoring and sponsorship, in particular, the location of African American females who serve at the elementary level can shift from one of concentrated influence to one that allows the knowledge and experiences of this group of administrators to reach levels of educational leadership that have largely been denied them. 
Pillar Number Three: Lift Every Voice

The last pillar of effective support for African American female elementary school principals is taken from a song that represents the struggle and hope of the African American people. Written by poet, author and educator James Weldon Johnson, "Lift Every Voice and Sing" is recited and sung by African Americans throughout the United States as a celebration of strength and heritage. The poem was first performed in 1900 by 500 school children at a segregated school to celebrate Abraham Lincoln's birthday and almost forty years of freedom for African Americans. Set to music five years later, the song "Lift Every Voice and Sing" soon became popular throughout the South eventually becoming known as the "Negro National Anthem."

Today, the singing of "Lift Every Voice and Sing" has become tradition in the Black community and is sung with pride by African Americans in churches, at community events and special galas. The call to lift Black voices in the struggle for freedom and equality is a sentiment still relevant in contemporary society. For African American women in educational leadership, whose voices have in effect been ignored by scholars and researchers, lifting one's voice means carving out a space for the lived experiences of a group of leaders of which little is known (Allen, et al., 1995; Benham, 1997; Bloom \& Erlandson, 2003; Pollard, 1997). The lifting the voices of African American women in education becomes "both a way to engage in active selftransformation and a rite of passage through which one moves from being object to 
being subject. As objects, [they] remain voiceless - [their] beings defined and interpreted by others" (Lorde, p. 2).

But, as Black women lift their voices, education scholars must be willing to listen. Listen not only to gain perspective, but listen to validate the experiences of a group of leaders that have contributed greatly to the field. Collins (2000) asserts that having a voice requires that there is an audience. Since the number of African American women attaining leadership positions is increasing and because these women are continually placed in urban settings, education scholars and practitioners must be that audience. Further research is needed that examines the lived experiences of African American women school leaders, particularly at the elementary level. The findings from this study and others indicate a strong influence of race and gender on the leadership functions of African American women and thus warrants further exploration. In addition, the hiring practices, assignment patterns and career mobility trends of African American female elementary administrators must be examined to ensure that these leaders have equal access to various placement and promotion opportunities.

\section{Implications}

Although this dissertation focused on the leadership experiences and perspectives of African American female school site administrators at the elementary school level, the study has implications for the larger field of educational leadership. The number of African American women taking the helm at urban elementary schools 
is increasing. The challenges they face in their efforts to educate students are unique and require the supports necessary to sustain them in their positions as leaders of the most under-resourced public schools. Findings from this study demonstrate an urgent need to provide support structures for African American female elementary school principals that facilitate their professional growth as well as their advancement to positions with greater influence. Districts and institutions of higher education must implement systems and programs that include opportunities for African American women to benefit from professional mentorships and cultural relationships. In addition, these institutions must seek out ways to foster the career advancement of African American women leading urban elementary schools as their unique leadership experiences and skill set can, unquestionably, positively influence the broader field of education leadership.

My research examined a group of African American women elementary school principals and attempted to capture their distinct and authentic views of the impact of race and gender on their leadership practice. To gain further insight into the lives of this particular group of leaders and to fill the gap in the literature on educational leadership, researchers must continue to investigate experiences and perspectives of African American women leading urban elementary schools, the challenges they encounter and how they successfully sustain in their roles as leaders. 


\section{Conclusion}

Despite the gains African American women have made in public school administration, their presence still remains a rarity in a male dominated field, and little is known about their experiences as documented in education research. This dissertation set forth to make visible the hidden experiences of six African American female elementary school principals in urban districts. Through narrative expression, these principals revealed their personal and professional lived experiences as they face various challenges on their quests to transform schools and increase student learning. Their experiences with racism, gender bias and negative stereotyping were documented as well as the structures they used to counter the challenges they confront in their roles as school site leaders. The figure below offers a representation of the pillars of effective support for African American female elementary school principals presented in this dissertation as recommendations for research and practice that developed from the findings of this study (see Figure 2). 


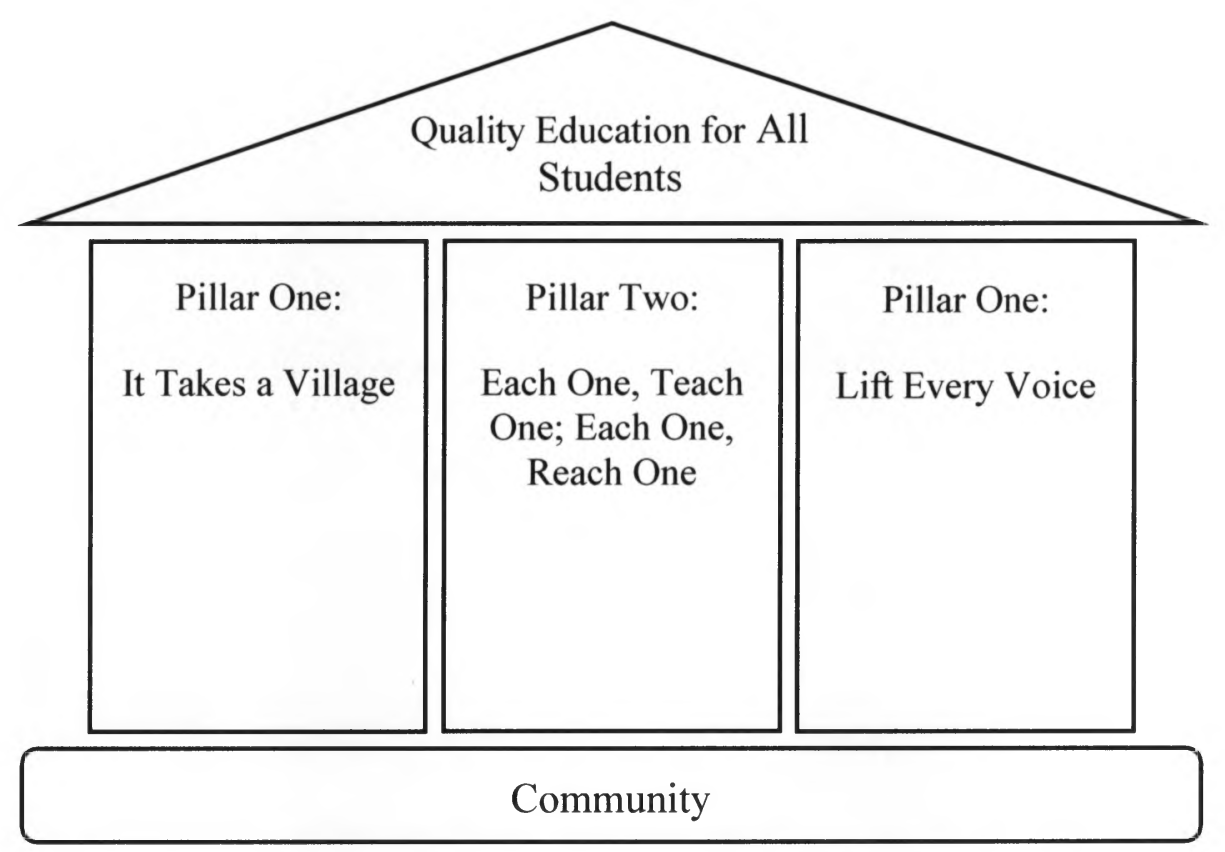

Figure 2: Pillars of Effective Support

As a profoundly personal endeavor, I wanted to document the challenges faced by Black women in their roles as elementary school principals despite their professional and personal isolation. I, too, sought to share the outstanding ability of Black women to persevere in the face of challenge and record the ways in which these women sustain in their positions and the structures they rely on for support. My hope is that this study be used as a catalyst for continued exploration of and examination into the lives of African American female elementary school principals. Literature that examines all areas of educational leadership must include the voices of African American women as they are changing the racial landscape of American school leadership. African American women must move from the "margins to the center" of dialogue in educational leadership 
(hooks, 1984). Their stories must be told and those charged with shaping antioppressive educational experiences for our nation's children must listen. 


\section{References}

Akom, A. A. (2003). Reexaming resistance as oppositional behavior: The Nation of Islam and the creation of a Black achievement ideology. Sociology of Education, 76(4), 305-325.

Albanese, A. (1976). The Plantation School. New York: Vantage Books.

Allen, K., Jacobson, S., \& Lomotey, K. (1995). African American Women in Educational Administration: The Importance of Mentors and Sponsors. The Journal of Negro Education, 64(4), 409-422.

Alston, J. A. (2000). Missing from action: Where are the Black female school superintendents? Urban Education, 35(5), 525.

Alston, J. A. (2005). Tempered Radicals and Servant Leaders: Black Females Persevering in the Superintendency. Educational Administration Quarterly, 41(4), 675.

Anderson, J. D. (1988). The Education of Blacks in the South, 1860-1935. Chapel Hill: University of North Carolina Press. 
Banks, C. A. M. (1995). Gender and race as factors in educational leadership. In A. Banks \& C. A. M. Banks (Eds.), Handbook of research on multicultural education (pp. 65-80). New York: Macmillan Publishers.

Beardon, J., \& Butler, L. J. (1977). Shadd: the Life and times of Mary Shadd Cary. Toronto: NC Press.

Bell, D. (1992). And we are not saved: the elusive quest for racial justice. New York: Basic Books.

Benham, M. K. P. (1997). Silences and Serenades: The Journeys of Three Ethnic Minority Women School Leaders. Anthropology \& Education Quarterly, 28(2), 280-307.

Bernhardt, V. L. (1998). Data analysis for comprehensive schoolwide improvement. Larchmont, NY: Eye on Education, Inc.

Bloom, C. M., \& Erlandson, D. A. (2003). African American women principals in urban schools: Realities, (re)constructions, and resolutions. Educational Administration Quarterly, 39(3), 339.

Bogdan, R. C., \& Biklen, S. K. (2003). Qualitative Research for Education: An introduction to Theories and Methods (4th ed.). New York: Pearson Education Group. 
Bogdan, R. C., \& Biklen, S. K. (2007). Qualitative research for education: An introduction to theories and methods (5th ed.). Boston: Allyn and Bacon.

Bogdan, R. C., \& Biklen, S. K. (2008). Qualitative research for education: An introduction to theories and methods (5 ed.). Boston: Allyn and Bacon.

Bolman, L. G., \& Deal, T. E. (1997). Reframing organizations: artistry, choice, and leadership (2nd ed.). San Francisco: Jossey-Bass Publishers.

Brown, F. (2005). African Americans and School Leadership: An Introduction. Educational Administration Quarterly, 4l(4), 585.

Brunner, C. C. (1999). Sacred Dreams: Women and the Superintendency.

Butchart, R. E. (1988). "Outthinking and outflanking the owners of the world": A historiography of the African American struggle for education. History of Education Quarterly, 28, 333-366.

Cammarota, J. (2004). The gendered and racialized pathways of Latina and Latino youth: Different struggles, different resistances in the urban context. Anthropology \& Education Quarterly, 35(1), 53-74. 
Carruthers, J. H. (1994). Black intellectuals and the crisis in Black Education. In M. J. Shujaa (Ed.), Too much schooling too little education: A paradox of black life in white societies (pp. 35-55). Trenton, New Jersey: Africa World Press, Inc.

Case, K. I. (1997). African American Othermothering in the Urban Elementary School. Urban Review, 29(1), 25-39.

Charmaz, K. (1983). The grounded theory method: An explication and interpretation. In R. M. Emerson (Ed.), Contemporary field Research: A Collection of Readings (pp. 109-128). Boston: Little, Brown and Company.

Cistone, P. J., \& Stevenson, J. M. (2000). Perspectives on the urban principalship. Education and Urban Society, 32(4).

Collins, P. H. (1998). Fighting words: Black women and the search for justice. Minneapolis: University of Minnesota Press.

Collins, P. H. (2000). Black feminist thought: knowledge, consciousness and the politics of empowerment. New York: Routledge.

Collins, P. H. (2002). Defining Black Feminist Thought. In P. Essed \& D. T. Goldberg (Eds.), Race Critical Theories (pp. 152-175). Malden, MA: Blackwell Publishing. 
Connelly, F. M., \& Clandinin, D. J. (1990). Stories of experience and narrative inquiry. Educational Researcher, 19(5), 2-14.

Cook, A. E. (1995). Beyond critical legal studies: The reconstructive theology of Dr. Martin Luther King. In K. Crenshaw, N. Gotanda, G. Peller \& K. Thomas (Eds.), Critical race theory: The key writings that formed the movement (pp. 85102). New York: The New Press.

Crawford, K., \& Smith, D. (2005). The We and the Us: Mentoring African American Women. Journal of Black Studies, 36(1), 52-67.

Creighton, T. (1999). Spirituality and the Principalship: Leadership for the New Millennium, 2011, from http://iejll.synergiesprairies.ca/iejll/index.php/iejll/article/viewFile/457/119

Crenshaw, K. (1988). Race, Reform and rentrenchment: Transformation and Legitimation n Anti-discrimination Law. Harvard Law Review, 101(7), 13311387.

Crenshaw, K. (1995). Mapping the margins: Intersectionality, identity politics, and violence against women of color. In K. Crenshaw, N. Gotanda, G. Peller \& K. Thomas (Eds.), Critical race theory: The key writings that formed the movement (pp. 357-383). New York: The New Press. 
Crenshaw, K., Gotanda, N., Peller, G., \& Thomas, K. (1995). Critical race theory: The key writings that formed the movement. New York: New Press.

Dalton, H. L. (1995). The clouded prism: Minority critique of the critical legal studies movement. In K. Crenshaw, N. Gotanda, G. Peller \& K. Thomas (Eds.), Critical race theory: The key writings that formed the movement (pp. 80-84). New York: The New Press.

Dardaine-Ragguet, P., \& et al. (1994). Female Administrators in Urban Settings: Legal Implications for Policy and Practice. Urban Education, 28(4), 398-411.

Davis, A. (1981). Women, race, and class. New York: Random House.

Davis, S., Darling-Hammond, L., LaPointe, M., \& Meyerson, D. (2005). School leadership study: Developing successful principals (Review of Research). Stanford, CA: Stanford University, Stanford Educational Leadership Institute.

DeCuir, J., T., \& Dixson, A. D. (2004). "So When It Comes Out, They Aren't That Surprised That It Is There": Using Critical Race Theory as a Tool of Analysis of Race and Racism in Education. Educational Researcher, 33(5), 26.

Delgado, R. (1989). Storytelling for Oppositionists and Others: A Plea for Narrative. Michigan Law Review, 87(8), 2411-2441. 
Delgado, R. (1995). Critical race theory: The cutting edge. Philadelphia, PA: Temple University Press.

Delgado, R., \& Stefancic, J. (2001). Critical Race theory: An Introduction: New York University Press.

Dillard, C. (1995). Leading with her life: An African American feminist (re) interpretation of leadership for an urban high school principal. Educational Administration Quarterly, 31, 539-563.

Doughty, R. (1980). The Black female administrator: Woman in a double bind. Lexington, MA: Lexington Books.

Duren, E. B. (2002). Voices from the margins: The oral histories of seventeen African American women teachers in K--12 public schools. Unpublished Ed.D., University of St. Thomas (Minnesota), United States -- Minnesota.

Fairclough, A. (2007). A Class of Their Own: Black Teachers in the Segregated South. Cambridge, MA: Belknap Press of Harvard University Press.

Fleming, S. Y. (1995). Bethune-Cookman College, 1904-1994: The answered prayer to a dream. Virginia Beach, VA: The Donring Company.

Fordham, S. (1996). Blacked Out: The University of Chicago Press. 
Franklin, V. P. (1984). Black self-determination: A cultural history of the faith of our fathers. Westport, CT.: Lawrence Hill.

Franklin, V. P. (1990). They rose and fell together: African American educators and community leadership. Journal of Educational Administration, 172(3), 39-64.

Gardiner, M. E., Enomoto, E., \& Grogan, M. (2000). Coloring outside the lines: Mentoring women into school leadership. Albany: State University of New York Press.

Giddings, P. (1984). When and Where I Enter: The Impact of Black Women on Race and Sex in America. New York: William Morrow.

Gollnick, D., \& Chinn, P. (2005). Multicultural education in a pluralistic society (7 ed.). Columbus: Upper Saddle River.

Gupton, S., \& Slick, G. (1996). Highly successful women administrators: The inside stories of how they got there. Thousand Oaks, CA: Corwin.

Harder, M., \& Waldo, K. (1983). Women as educational leaders: the theories behind the facts. Action in Teacher Education, 5, 35-40. 
Harris, C. I. (1995). Whiteness as property. In K. Crenshaw, N. Gotanda, G. Peller \& K. Thomas (Eds.), Critical race theory: The key writings that formed the movement. New York: The New Press.

Hawkins, B. D. (1994). Casualties: Losses among Black educators were high after Brown. Black Issues in Higher Education, 10, 34-35.

Helgesen, S. (1990). The Female Advantage: Women's Ways of Leadership: Doubleday.

Hill, M. S., \& Ragland, J. C. (1995). Women as educational leaders: Opening windows, pushing ceilings. Thousand Oaks, CA: Corwin Press.

Holt, R. (1964). Mary McLeod Bethune: A biography. New York: Doubleday \& Co.

hooks, b. (1981). Ain't I a woman: Black women and feminism. Boston: South End Press.

hooks, b. (1984). Feminist theory: From margin to center. Boston: South End Press.

Howard-Vital, M., \& Morgan, R. (1993). African American women and mentoring. East Lansing, MI: National Center for Research on Teacher Learning.

Irvine, J. J. (1999). The education of children whose nightmares come both day and night. Journal of Negro Education, 68, 224-253. 
Jackson, B. L., \& Kelley, C. (2002). Exceptional and innovative programs in educational leadership. Educational Administration Quarterly, 38(2), 192-212.

Johnson-Miller, B. C. (2006). Mary McLeod Bethune: Black educational ministry leader of the early 20th century. Christian Education Journal, 3(2), 330-342.

Johnson, K. A. (2000). Uplifting the Women and the Race: The Educational Philosophies and Social Activism of Anna Julia Cooper and Nannie Helen Burroughs. New York: Garland Publishing.

Jones, C., \& Shorter-Gooden, K. (2003). Shifting: The double lives of Black women in American. New York: HarperCollins.

Jones, E., \& Montenegro, X. (1985). Women and minorities in school administration. Washington, DC: Office of Minority Affairs, American Association of School Administrators.

Jorgensen, D. L. (1989). Participant observation: Methodology for human studies. Newbury, CA: Sage.

King, D. (1995). Multiple jeopardy, multiple consciousness: the context of a black feminist ideology Words of fire: an anthology of African American feminist thought. New York: The New Press Publishing. 
Knapp, M. S., Copland, M. A., Plecki, M. L., \& Portin, B. S. (2006). Leading, learning, and leadership support. Seattle, WA: Center for the Study of Teaching and Policy, University of Washington.

Knapp, M. S., Copland, M. A., \& Talbert, J. E. (2003). Leading for learning: Reflective tools for school and district leaders. Seattle, WA: Center for the Study of Teaching and Policy.

Ladson-Billings, G. (1994). The dreamkeepers. San Francisco: Jossey-Bass Publishing Co.

Ladson-Billings, G. (2003). It's Your World, I'm Just Trying to Explain It: Understanding Our Epistemological and Methodological Challenges. Qualitative Inquiry, 9(1), 5-12.

Ladson-Billings, G., \& Tate, W. F. (1995). Toward a critical theory of education. Teachers College Record, 97, 47-68.

Lawson, E. N., \& Merrill, M. (1983). The Antebellum 'Talented Thousandth': Black College Students at Oberlin Before the Civil War. The Journal of Negro Education, 87, 390-402.

Leithwood, K., Seashore-Louis, K., Anderson, S., \& Wahlstrom, K. (2004). How leadership influences student learning. New York: The Wallace Foundation. 
Loder-Jackson, T. (2009). The confluence of Race, Gender, and Generation in the Lives of African American Women Principals: Sage Publications.

Loder, T. L. (2005). African American Women Principals' Reflections on Social Change, Community Othermothering, and Chicago Public School Reform. Urban Education, 40(3), 298-320.

Logan, R. W., \& Winston, M. R. (1982). Dictionary of American Negro Biography. New York: W.W. Norton.

Lomotey, K. (1993). African American principals: Bureaucrat/administrators and ethnohumanists. Urban Education, 27, 394-412.

Lorde, A. (1984). Sister outsider: Essays and speeches. Trumansburg, NY: Crossing Press.

Lyons, J. E., \& Chesley, J. (2004). Fifty Years after Brown: The Benefits and Tradeoffs for African American Educators and Students. The Journal of Negro Education, 73(3), 298-313.

Matsuda, M. (1991). Voices of America: Accent, antidiscrimination law, and a jurisprudence for the last reconstruction. Yale Law Journal, 100, 1329-1407.

McAdoo, H. P. (2007). Black Families. Thousand Oaks: Sage Publications. 
McCray, C., Wright, J., \& Beachum, F. (2007). Beyond Brown: Examining the Perplexing Plight of African American Principals. Journal of Instructional Psychology, 34(4), 247.

Murtadha, K., \& Watts, D. M. (2005). Linking the Struggle for Education and Social Justice: Historical Perspectives of African American Leadership in Schools. Educational Administration Quarterly, 41(4), 591.

Parker, L. (2003). Critical race theory and its implications for methodology and policy analysis in higher education desegregation. In G. R. Lopez \& L. Parker (Eds.), Interrogating racism in qualitative education methodology (pp. 145-173). New York: Peter Lang.

Patton, M. (1990). Designing qualitative studies. Qualitative evaluation and research methods. New York: Teachers College Press.

Perkins, L. (1987). Fannie Jackson Coppin and the Institute for Colored Youth, 18651902. New York: Garland.

Pollard, D. (1997). Race, Gender, and Educational Leadership: Perspectives From African American Principals. Educational Policy, 11(3), 353-374.

Pool, C. R. (1997). Hope in Chicago. Educational Leadership, 54(7), 33-36. 
Quinn, D. M. (2002). The impact of principal leadership behaviors on instructional practice and engagement. Journal of Educational Administration, 40(5), 447467.

Reitzug, U. C., \& Patterson, J. (1998). "I'm not going to lose you!" Empowerment through caring in urban principal's practice with students. Urban Education, 33, $150-181$.

Revere, A. (1985). A description of Black female school superintendents. Unpublished Dissertation, Miami University.

Rhodes, J. (1998). Mary Ann Shadd Cary: the Black Press and Protest in the Nineteenth Century. Bloomington: Indiana University Press.

Rubenstein, R., \& Miller, L. (2005). Allocating resources within a big city school district: NYC after Campaign for Fiscal Equity v. New York: Policy Brief No. 31.

Savage, C. G. (2001). "Because we did more with less": The agency of African American teachers in Franklin, Tennessee: 1890-1967 Peabody Journal of Education, 76, 170-203.

Sernak, K. (2001). School leadership: Balancing power with caring. New York: Teachers College. 
Sherman, W. H., Beaty, D. M., Crum, K. S., \& Peters, A. (2010). Unwritten: young women faculty in educational leadership. Journal of Educational Administration, 48(6), 741-754.

Siddle Walker, V. (1996). Their highest potential: An African American school community in the segregated South. Chapel Hill: University of North Carolina.

Siddle Walker, V. (2003). The architects of Black schooling in the segregated South: The case of one principal leader. Journal of Curriculum and Supervision, 19, $54-72$.

Singh, J., Robinson, A., \& Williams-Green, J. (1995). Differences in perceptions of African American women and men faculty and administrators. Journal of Negro Education, 64(4), 401-408.

Smith-Campbell, S. I. (2002). Exploring the work of Black women middle school principals. Unpublished Ph.D., Michigan State University, United States -Michigan.

Smith, A. B. (1997). Forgotten foundations: The role of Jeanes teachers in Black education. New York: Vantage Press. 
Solorzano, D., Ceja, M., \& Yosso, T. (2000). Critical Race Theory, Racial Microaggressions, and Campus Racial Climate: The Experiences of African American College Students. Journal of Negro Education, 69, 60-73.

Solorzano, D., \& Yosso, T. (2002). Critical race methodology:Counter-storytelling as an analytical frameork fro education research. Qualitative Inquiry, 8(1), 23-44.

Solorzano, D. G., \& Yosso, T. J. (2001). From racial stereotyping and deficit discourse toward a critical race theory in teacher education. Multicultural Education, 9(1), 2.

Taylor, C. R. (2004). An inquiry into the experiences of the African American women principal: Critical race theory and black feminist perspectives. Unpublished Dissertation.

Taylor, E. (1998). A primer on critical race theory. Journal of Blacks in Higher Education, 19(Spr 1998), 122-124.

Tharenou, P. (2001). "Going up? Do traits and informal social processes predict advancing in management? Academy of Management Journal, 44, 1005-1017.

Tillman, L. C. (2002). Culturally sensitive research approaches: An African American perspective. Educational Researcher, 31(9), 3-12. 
Tillman, L. C. (2004a). African American Principals and the Legacy of "Brown". Review of Research in Education, 28, 101-146.

Tillman, L. C. (2004b). (Un)intended consequences? The impact of the Brown v. Board of Education decision on the employment status of black educators. Education and Urban Society, 36(3), 280.

Vaill, P. V. (1998). Spirited leading and learning: Process wisdom for a new age. San Francisco: Jossey-Bass.

Waring, A. L. (2003). African American female college presidents: Self conceptions of leadership. Journal of Leadership \& Organizational Studies, 9(3), 31.

Waters, T., \& Grubb, S. (2004). The leadership we need: Using research to strengthen the use of standards for administrator preparation and licensure programs. Aurora, CO: Mid-continent Research for Education and Learning.

Waters, T., Marzano, R. J., \& McNulty, B. (2003). Balanced leadership: What 30 years of research tells us about the effects of leadership on student achievement. Aurora, CO: Mid-continent Research for Education and Learning.

Webber, T. (1978). Deep Like Rivers: Education in the Slave Quarter Community 18311865. New York: W.W. Norton \& Company, Inc. 
Whitaker, K. S., \& Lane, K. (1990). What is “a woman's place” in educational administration? Education Digest, 56(3), 12-16.

Williams, H. A. (2007). Self-Taught: African American Education in Slavery and Freedom University of North Carolina Press.

Yeakey, C. C., Johnston, G. S., \& Adkison, J. A. (1986). In pursuit of equity: A review of research on minorities and women in educational administration. Educational Administration Quarterly, 22, 110-149. 


\title{
Appendix A
}

\author{
Introduction Letter/Email
}

[Date]

[Address]

Dear Ms./Mrs./Dr. [Last Name]

My name is Vidrale Antoinette Franklin and I am an elementary school principal in San Francisco Unified School District. I have worked during the past two years at San Francisco State University completing my doctorate degree in Educational Leadership. I am contacting you because you were identified as an African American female principal leading an elementary school within your district. Because there is a dearth of information on African American women principals, I have relied on professional colleagues, professional organizations and personal telephone contacts to locate you and ask for your participation in a study I am conducting for my dissertation.

My research will explore the experiences, practices and beliefs of African American women in their role as elementary school principals. Some of the areas I am examining are workplace experiences, personal background, decision-making, and the barriers and facilitators to your work as school leaders. I chose to conduct a study that focuses on this group of educators because the current professional literature does not present the experiences of African American women in educational leadership at the elementary level nor does it detail how we think about our roles, and what contributes to or hinders our leadership.

I invite you to participate in this research because you are an African American women serving as an elementary school principal. Your participation will consist of a onehour interview, a demographic questionnaire and four journal entries that encourage reflection on your role as a school leader in the context of race, class and gender. I realize, as a school administrator, you are extremely busy and your commitment will be much appreciated.

I would like to hear your voice and I hope that you will give me as well as many others an opportunity to listen.

If you have any questions, please feel free to contact me or my advisor, Dr. Jamal Cooks at jcooks@sfsu.edu. Thank you for your time and consideration. 
Appendix B

Informed Consent

\section{San Francisco State University \\ Informed Consent to Participate in a Research Study \\ Race, Class, Gender: Reflections of African American Female Elementary School Principals}

The purpose of this research study is to learn more about the experiences of African American female elementary principals in urban settings. The researcher, Vidrale Antoinette Franklin, is a graduate student/ at San Francisco State University conducting research for a doctoral dissertation in Educational Leadership.

You are being asked to participate in this study because you are an African American female school administrator at the elementary school level.

\section{Procedures}

If you agree to participate in this research study, the following will occur:

- you will be interviewed for approximately sixty minutes about your role as a school leader in an urban setting.

- the interview will be audiotaped to ensure accuracy in reporting your statements.

- the interview will take place at a location of your choice at a time convenient for you.

- you will be asked to complete a demographic questionnaire about your background leading up to your position.

- you will be asked to reflect on your role in terms of race, gender and class using an online or physical journal weekly for four weeks. Online journals will be sent via email weekly. Physical journals will be sent using a pre-addressed, postage paid envelope at the completion of the study.

- the researcher may contact you later to clarify your interview answers for approximately fifteen approximately forty-five minutes.

- total time commitment will be $2 \frac{1}{2}$ hours.

\section{$\underline{\text { Risks }}$}

There is a risk of loss of privacy. However, no names or identities or school/institution names will be used in any published reports of the research. Only the researcher will have 
access to the research data. There is a risk of discomfort and you may refrain from answering any question(s) or stop participation at any time without penalty.

\section{Confidentiality}

The research data will be kept in a secure location and only the researcher will have access to the data. At the conclusion of the study, all identifying information will be removed and the data, including audiotapes and transcripts, will be kept in a locked cabinet or office. Names and school names will not be used in the written study report.

\section{Direct Benefits}

There will be no direct benefits to the participant.

\section{$\underline{\text { Costs }}$}

There will be no cost to you for participating in this research.

\section{Compensation}

None

\section{$\underline{\text { Alternatives }}$}

The alternative is not to participate in the research.

\section{Questions}

You have spoken with Vidrale Antoinette Franklin about this study and have had your questions answered. If you have any further questions about the study, you may contact the researcher by email at vidrale@sfsu.edu or you may contact the researcher's advisor, Professor Jamal Cooks at cooksj@sfsu.edu. Questions about your rights as a study participant, or comments or complaints about the study, may also be addressed to the Office for the Protection of Human Subjects at 415: 338-1093 or protocol@sfsu.edu.

\section{Consent}

You have been given a copy of this consent form to keep. 
PARTICIPATION IN THIS RESEARCH IS VOLUNTARY. You are free to decline to participate in this research study, or to withdraw your participation at any point, without penalty. Your decision whether or not to participate in this research study will have no influence on your present or future status at San Francisco State University.

Signature:

Date:

Research Participant

Signature:

Date:

Researcher 
Appendix C

Demographic Questionnaire

1. Name:

2. Your age:

3. Degree(s) earned:

O bachelor's O master's O doctorate

4. Number of years as an educator (including this year):

$O$ less than 5 years $\bigcirc$ 6-10 years $\bigcirc 11-15$ years $\bigcirc 16-20$ years $\bigcirc 21$ years +

5. Number of years as a school site administrator (including this year):

$O$ less than 5 years $\bigcirc$ 6-10 years $\bigcirc 11-15$ years $\bigcirc 16-20$ years $\bigcirc 21$ years +

6. Number of years at your current school (including this year):

$O$ less than 5 years $\bigcirc$ 6-10 years $\bigcirc 11-15$ years $\bigcirc 16-20$ years $\bigcirc 21$ years +

7. Current marital status: $O$ married Osingle Oseparated $O$ divorced

8. Number of children: $\quad \bigcirc$ none $\quad$ 1-2 $\quad$ 3-4 $\bigcirc 5$ or more

9. Growing up, how would you classify your family income level? O Upper middle class $O$ Middle class $\bigcirc$ Working class

O Economically disadvantaged

10. Highest level of education achieved by your parents:
O some high school
O high school graduate
$\mathrm{O}$ undergraduate degree
graduate degree 
Appendix D

Interview Questions

1. Tell me about your journey to the principalship.

2. Looking back at your life, who had the greatest impact on you to pursue a career in educational leadership? Explain.

3. Define your role as an African American elementary school principal.

4. What experiences would you view as illustrations of your role as principal in an urban school district?

5. How does your race and gender impact your work and how others perceive your work?

6. What are some of the barriers and challenges you have overcome in your position as an African American elementary school site administrator?

7. What supports have you utilized in your role as principal? What structures have you created to support you (personally and professionally) and others?

8. As an African American female school leader, how do you measure success?

9. What else should people know about you as an African American female school leader? 